\author{
UNIVERSIDADE DE SÃO PAULO \\ INSTITUTO DE QUÍMICA DE SÃO CARLOS \\ DEPARTAMENTO DE QUÍMICA E FÍSICA MOLECULAR
}

\title{
ESTUDOS ESPECTROSCÓPICOS DAS INTERAÇÕES DE SURFACTANTES COM A CADEIA MONOMÉRICA $d$ DA HEMOGLOBINA DE Glossoscolex paulistus
}

Julio Carlos Ribelatto

Tese apresentada ao Instituto de Química de São Carlos, da Universidade de São Paulo para obtenção do título de Doutor em Ciências. Área de concentração: Química Analítica

Orientador: Prof. Dr. Hidetake Imasato

São Carlos / SP

2008 
Dedico este trabalho aos meus pais Valdemar e Terezinha por me apoiarem com muito amor e carinho e dedicação durante todos os momentos de minha vida. 


\section{AGRADECIMENTOS}

Ao Prof. Dr. Hidetake Imasato pela orientação e paciência em me ensinar.

Aos professores do Grupo de Biofísica Molecular e de Fotossensibilizadores, pela infra-estrutura disponibilizada.

À Andressa Patrícia e a Isabel, técnicas do laboratório de Biofísica Molecular do Instituto de Física de São Carlos, pelas medidas de dicroísmo circular.

À Alessandra Lima Poli pelo amplo apoio durante todo o meu mestrado e doutorado, abrangendo discussões teóricas, elaboração de papers, experimentos e principalmente, pela nossa grande amizade.

Ao Prof. Dr. Leonardo Marmo Moreira pela amizade, e por todas as discussões científicas e excelente convivência.

Ao pessoal do laboratório de Biofísica: Patrícia, Marilene, Michele, Shirley, Marco Aurélio, Diógenes, Angel e o Ézer pela convivência muito humorada no dia a dia.

Aos amigos do Grupo de Fotossensibilizadores: Priscila, Suéllen, Márcio, Juliana, Roberta e Cláudia.

Á Janaína, Márcio, Aline, Sérgio, Ricardo e Ana Paula, amigos que conheci em São Carlos, no qual sempre estarão comigo nos momentos de alegria ou de tristeza, mas o principal, sempre unidos.

Aos amigos que conheci no Instituto de Química de São Carlos. 
Aos meus novos amigos da UNICEP, pelas conversas agradáveis, festas, churrascos, baladas.

A minha paciente Juliane, pelo carinho, compreensão, sinceridade, paciência. Desde já, me perdoe pela ausência em vários momentos de nossas vidas.

Aos meus amigos de graduação da Universidade Federal de São Carlos.

À Vanessa, secretária do grupo, pelas inúmeras ligações telefônicas e disposição em ajudar.

Ao pessoal da biblioteca do IQSC e da sessão de pós-graduação, por toda dedicação.

A Deus pela minha vida, saúde e por estar sempre junto de mim. 


\section{SUMÁRIO}

LISTA DE FIGURAS......................................................................................

LISTA DE TABELAS ....................................................................................... ix

LISTA DE ABREVIATURAS E SÍMBOLOS .................................................

RESUMO ..................................................................................................

ABSTRACT.............................................................................................. xii

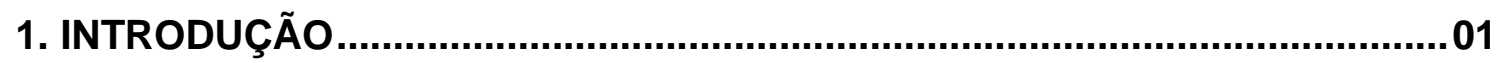

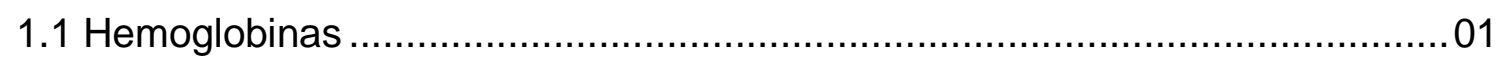

1.2 Hemoglobinas Extracelulares Gigantes ................................................ 07

1.3 Hemoglobina extracelular de Glossoscolex paulistus ................................... 12

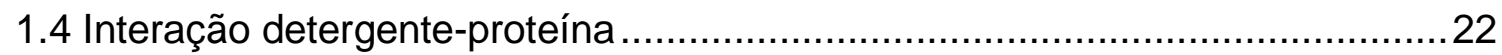

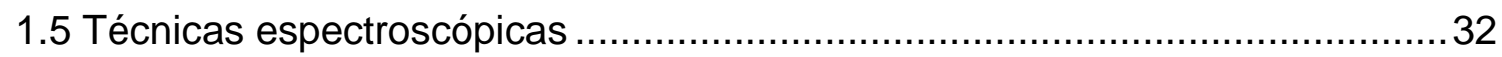

1.5.1 O Espectro de absorção na região do ultravioleta-visível das porfirinas ......32

1.5.2 Dicroísmo Circular em hemoproteínas ....................................................... 34

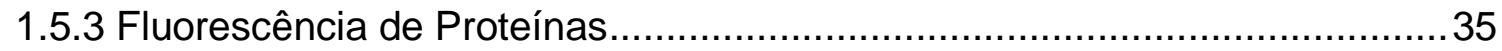

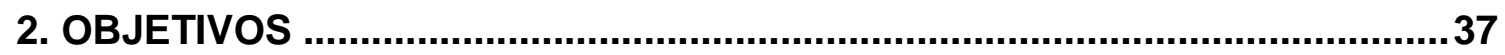

3. MATERIAIS E MÉTODOS ............................................................................ 38

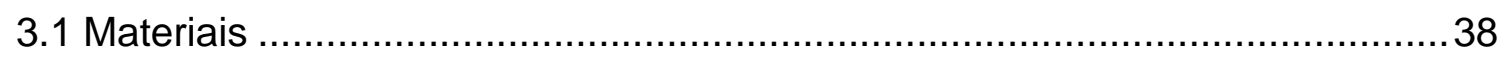

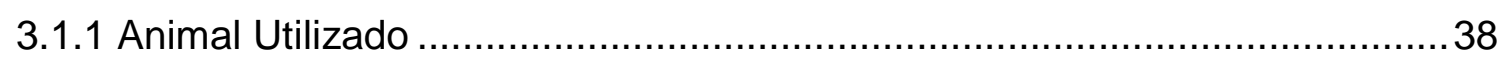

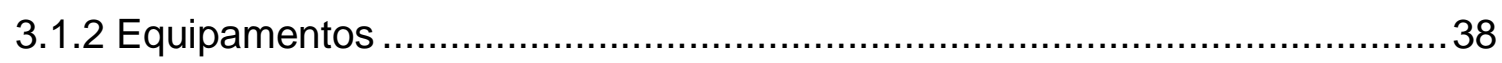

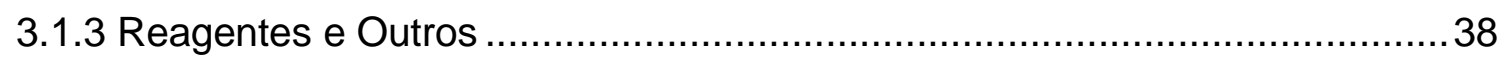

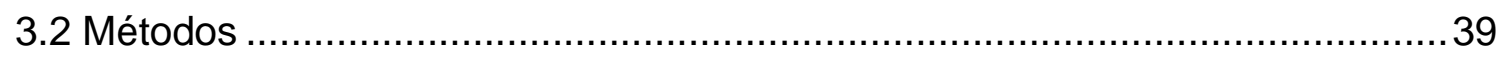

3.2.1 Obtenção e purificação - Oxi-hemoglobina íntegra e Monômero .................39

3.2.2 Medidas de Absorção Ótica .................................................................. 40

3.2.3 Medidas de Fluorescência ............................................................. 41

3.2.4 Medidas de Dicroísmo Circular ................................................................. 42 
4. RESULTADOS.

4.1 Estudo da interação da fração oxi-monômero em pH 7,0 e 9,0 da hemoglobina de G. paulistus (HbGp) com SDS, CTAC e BRIJ-35 através da fluorescência e

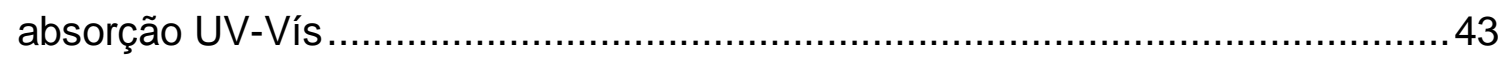

4.1.1 Titulação do oxi-monômero da HbGp com SDS em pH 7,0 ........................44

4.1.2 Titulação do oxi-monômero da HbGp com SDS em pH 9,0 ........................49

4.1.3 Titulação do oxi-monômero da HbGp com CTAC em pH 7.0 .......................54

4.1.4 Titulação do oxi-monômero da HbGp com CTAC em pH 9,0 ......................61

4.1.5 Titulação do oxi-monômero da HbGp com BRIJ-35 em pH 7,0...................69

4.1.6 Titulação do oxi-monômero da HbGp com BRIJ-35 em pH 9,0...................76

4.2 Estudo da interação da fração oxi-monômero em pH 7,0 e 9,0 da hemoglobina de G. paulistus (HbGp) com SDS, CTAC e BRIJ-35 através do dicroísmo circular 


\section{ÍNDICE DE FIGURAS}

Figura 1: Representação do grupo heme, que é um componente essencial em hemoglobinas, citocromos e enzimas como catalases e peroxidases 3

Figura 2: Grupo heme, sua proximidade com as histidinas F8 e E7 e o local de ligação da molécula de $\mathrm{O}_{2}:(A)$ vista espacial; (B) vista lateral 4

Figura 3: Representação da histidina $\mathrm{E} 7$, distal, proporcionando estabilidade à ligação $\mathrm{Fe}-\mathrm{O}_{2}$ através da formação de uma ligação de hidrogênio entre $0 \mathrm{NH}$ do imidazol e o oxigênio molecular 7

Figura 4: Representação esquemática da hemoglobina de HBLt 8

Figura 5: Modelos dos arranjos espaciais da hemoglobina íntegra, do dodecâmero e do tetrâmero de Lumbricus terrestris (Royer, 2001) 9

Figura 6: Foto do anelídeo G. paulistus, conhecido popularmente como minhocoçu. 12

Figura 7: Representação das três principais espécies presentes tanto em meio alcalino como em meio ácido

Figura 8: Posições dos triptofanos no interior do modelo do monômero $d$ da hemoglobina de G. paulistus. 22

Figura 9: Estrutura química dos surfactantes: aniônico: Dodecil Sulfato de Sódio (SDS); catiônico: Cloreto de Cetiltrimetilamônio (CTAC), e neutro: Polioxietileno Lauril Éter (BRIJ - 35) 
Figura 10: Representação esquemática da ligação do surfactante à proteína nativa $(P)$ e o subseqüente processo de desnaturação 27

Figura 11: Modelos para a interação proteína-surfactante 28

Figura 12: Estruturas possíveis para os complexos proteína-surfactante no modelo "colar de pérolas". (A) A cadeia polipeptídica se enrola ao redor da micela; (B) As micelas encontram-se nucleadas nos sítios hidrofóbicos da proteína 29

Figura 13: Aminoácidos fluorescentes 36

Figura 14: Espectros de absorção no UV-Vís do oxi-monômero de G. paulistus em tampão Tris-HCl 20 mmol L'-1 pH 7,0 em função da concentração de SDS na faixa de $0,005-1,0 \mu \mathrm{M}$ 41

Figura 15: Áreas normalizadas dos espectros de emissão do oxi-monômero de $G$. paulistus em tampão Tris- $\mathrm{HCl} 20 \mathrm{mmol} \mathrm{L}^{-1}(\mathrm{pH} 7,0), \lambda_{\mathrm{exc}}=295 \mathrm{~nm}, \lambda_{\mathrm{em}}=305-450$ nm, em função da concentração de SDS 47

Figura 16: (A) Espectros de emissão do oxi-monômero de G. paulistus em tampão Tris- $\mathrm{HCl} 20 \mathrm{mmol} \mathrm{L}^{-1}$ (pH 7,0), $\lambda_{\mathrm{exc}}=295 \mathrm{~nm}$ em função da concentração de SDS, (B) espécies puras: oxi-monômero puro (-๑) - espécie 1, complexo monômero-SDS (- -) - espécie 2 e monômero desnaturado (- $\left.\Delta^{-}\right)$- espécie 3 , correspondentes aos componentes dos espectros experimentais presentes em 
diferentes proporções; (C) conteúdo relativo de cada espécie em função da concentração de SDS 48

Figura 17: Espectros de absorção no UV-Vís do oxi-monômero de G. paulistus em tampão Tris-HCl 20 mmol L-1, pH 9,0, em função da concentração de SDS na faixa de $0,005-1,2 \mu \mathrm{M}$ 49

Figura 18: Áreas normalizadas dos espectros de emissão do oxi-monômero de $G$. paulistus em tampão Tris- $\mathrm{HCl} 20 \mathrm{mmol} \mathrm{L}^{-1}(\mathrm{pH} 9,0), \lambda_{\mathrm{exc}}=295 \mathrm{~nm}, \lambda_{\mathrm{em}}=305-450$ $\mathrm{nm}$, em função da concentração de SDS. 51

Figura 19: (A) Espectros de emissão do oxi-monômero de G. paulistus em tampão Tris- $\mathrm{HCl} 20 \mathrm{mmol} \mathrm{L}^{-1}(\mathrm{pH} 9,0), \lambda_{\mathrm{exc}}=295 \mathrm{~nm}$ em função da concentração de SDS, (B) espécies puras: oxi-monômero puro $(-\bullet-)$ - espécie 1 , complexo monômero-SDS (- -) - espécie 2 e monômero desnaturado (- - $^{-}$- espécie 3 , correspondentes aos componentes dos espectros experimentais presentes em diferentes proporções; (C) conteúdo relativo de cada espécie em função da concentração de SDS 53

Figura 20: (A) Espectros de absorção do UV-Vís do oxi-monômero de G. paulistus em tampão Tris-HCl $20 \mathrm{mmol} \mathrm{L}^{-1}(\mathrm{pH}$ 7,0), função da concentração de CTAC na faixa de 0,005-1,1 $\mu \mathrm{M}$, (B) espécies puras: oxi-monômero puro (-•-) - espécie 1, espécie pentacoordenada (--) - espécie 2, correspondentes aos componentes 
dos espectros experimentais presentes em diferentes proporções; (C) conteúdo relativo de cada espécie em função da concentração de CTAC 54

Figura 21: Gráfico de absorbância do oxi-monomero de G. paulistus em tampão Tris-HCl 20 mmol L-1 (pH 7,0), em função da concentração de CTAC, na região da banda de Soret. 56

Figura 22: Gráfico de absorbância do oxi-monomero de G. paulistus em tampão Tris- $\mathrm{HCl} 20$ mmol L $^{-1}$ (pH 7,0), em função da concentração de CTAC, na região da banda Q (541 e 575) e na banda $605 \mathrm{~nm}$. 57

Figura 23: Áreas normalizadas dos espectros de emissão do oxi-monômero de G. paulistus em tampão Tris-HCl $20 \mathrm{mmol} \mathrm{L}^{-1}(\mathrm{pH} 7,0), \lambda_{\mathrm{exc}}=295 \mathrm{~nm}, \lambda_{\mathrm{em}}=305-450$ nm, em função da concentração de CTAC 58

Figura 24: (A) Espectros de emissão do oxi-monômero de G. paulistus em tampão Tris-HCl $20 \mathrm{mmol} \mathrm{L}^{-1}(\mathrm{pH} 7,0), \lambda_{\mathrm{exc}}=295 \mathrm{~nm}$ em função da concentração de CTAC, (B) espécies puras: oxi-monômero puro $(-\bullet-)$ - espécie 1 , complexo monômero-CTAC (- - - - espécie 2 e monômero desnaturado (- $\mathbf{\Delta}_{-}^{-}$- espécie 3 , correspondentes aos componentes dos espectros experimentais presentes em diferentes proporções; (C) conteúdo relativo de cada espécie em função da concentração de CTAC 60 
Figura 25: (A) Espectros de absorção no UV-Vís do oxi-monômero de G. paulistus em tampão Tris-HCl 20 mmol L ${ }^{-1}(\mathrm{pH} 9,0)$, função da concentração de CTAC na faixa de 0,005-1,6 $\mu \mathrm{M},(\mathrm{B})$ espécies puras: oxi-monômero puro (-๑-) - espécie 1, espécie pentacoordenada (-口-) - espécie 2, correspondentes aos componentes dos espectros experimentais presentes em diferentes proporções; (C) conteúdo relativo de cada espécie em função da concentração de CTAC 61

Figura 26: Gráfico de absorbância do oxi-monomero de G. paulistus em tampão Tris- $\mathrm{HCl} 20$ mmol L-1 $(\mathrm{pH} 9,0)$, em função da concentração de CTAC, na região da banda de Soret. 64

Figura 27: Gráfico de absorbância do oxi-monomero de G. paulistus em tampão Tris-HCl $20 \mathrm{mmol} \mathrm{L}^{-1}(\mathrm{pH} 9,0)$, em função da concentração de CTAC, na região da banda Q (541 e 575) e na banda $605 \mathrm{~nm}$ 65

Figura 28: Áreas normalizadas dos espectros de emissão do oxi-monômero de G. paulistus em tampão Tris- $\mathrm{HCl} 20 \mathrm{mmol} \mathrm{L}^{-1}(\mathrm{pH} 9,0), \lambda_{\text {exc }}=295 \mathrm{~nm}, \lambda_{\text {em }}=305-450$ nm, em função da concentração de CTAC 67

Figura 29: (A) Espectros de emissão do oxi-monômero de G. paulistus em tampão Tris- $\mathrm{HCl} 20 \mathrm{mmol} \mathrm{L}^{-1}(\mathrm{pH} 9,0), \lambda_{\mathrm{exc}}=295 \mathrm{~nm}$ em função da concentração de CTAC, (B) espécies puras: oxi-monômero puro (-匹-) - espécie 1, complexo

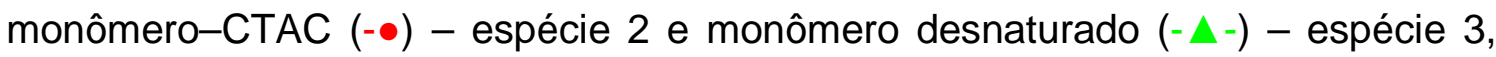


correspondentes aos componentes dos espectros experimentais presentes em diferentes proporções; (C) conteúdo relativo de cada espécie em função da concentração de CTAC 68

Figura 30: (A) Espectros de absorção no UV-Vís do oxi-monômero de G. paulistus em tampão Tris-HCl 20 mmol L-1 (pH 7,0), função da concentração de BRIJ-35 na faixa de 4,0-452 $\mu \mathrm{M}$, (B) espécies puras: oxi-monômero puro (-•-) - espécie 1, oximonômero desnaturado (--) - espécie 2, correspondentes aos componentes dos espectros experimentais presentes em diferentes proporções; (C) conteúdo relativo de cada espécie em função da concentração de BRIJ-35. 69

Figura 31: Gráfico de absorbância do oxi-monomero de G. paulistus em tampão Tris- $\mathrm{HCl} 20 \mathrm{mmol} \mathrm{L}^{-1}(\mathrm{pH} 7,0)$, em função da concentração de BRIJ-35, na região da banda de Soret. 71

Figura 32: Gráfico de absorbância do oxi-monomero de G. paulistus em tampão Tris- $\mathrm{HCl} 20 \mathrm{mmol} \mathrm{L}^{-1}(\mathrm{pH} 7,0)$, em função da concentração de BRIJ-35, na região da banda $\mathrm{Q}, 538$ e $576 \mathrm{~nm}$, respectivamente 72

Figura 33: Áreas normalizadas dos espectros de emissão do oxi-monômero de G. paulistus em tampão Tris- $\mathrm{HCl} 20 \mathrm{mmol} \mathrm{L}^{-1}(\mathrm{pH} 7,0), \lambda_{\mathrm{exc}}=295 \mathrm{~nm}, \lambda_{\mathrm{em}}=305-450$ nm, em função da concentração de BRIJ-35 73 
Figura 34: (A) Espectros de emissão do oxi-monômero de G. paulistus em tampão Tris-HCl 20 mmol L-1 $(\mathrm{pH} 7,0), \lambda_{\text {exc }}=295 \mathrm{~nm}$ em função da concentração de BRIJ-35, (B) espécies puras: oxi-monômero puro (-•-) - espécie 1, complexo monômero-BRIJ-35 (- $\Delta$-) - espécie 2 e monômero desnaturado (-口-) - espécie 3, correspondentes aos componentes dos espectros experimentais presentes em diferentes proporções; (C) conteúdo relativo de cada espécie em função da concentração de BRIJ-35. 75

Figura 35: (A) Espectros de absorção no UV-Vís do oxi-monômero de G. paulistus em tampão Tris-HCl 20 mmol L-1 (pH 9,0), função da concentração de BRIJ-35 na faixa de 5,4-1007 $\mu \mathrm{M},(\mathrm{B})$ espécies puras: oxi-monômero puro (- $\mathbf{\Delta}$-) - espécie 1, possível espécie pentacoordenada (-๑-) - espécie 2, monômero desnaturado (-1-) - espécie 3, correspondentes aos componentes dos espectros experimentais presentes em diferentes proporções; (C) conteúdo relativo de cada espécie em função da concentração de BRIJ-35 76

Figura 36: Gráfico de absorbância do oxi-monomero de G. paulistus em tampão Tris-HCl 20 mmol L-1 $(\mathrm{pH}$ 9,0), em função da concentração de BRIJ-35, na região da banda de Soret 78

Figura 37: Gráfico de absorbância do oxi-monomero de G. paulistus em tampão Tris-HCl 20 mmol L-1 $(\mathrm{pH} 9,0)$, em função da concentração de BRIJ-35, na região da banda Q, 540 e $574 \mathrm{~nm}$, respectivamente 79 
Figura 38: Áreas normalizadas dos espectros de emissão do oxi-monômero de $G$. paulistus em tampão Tris- $\mathrm{HCl} 20 \mathrm{mmol} \mathrm{L}^{-1}(\mathrm{pH} 9,0), \lambda_{\mathrm{exc}}=295 \mathrm{~nm}, \lambda_{\mathrm{em}}=305-450$ nm, em função da concentração de BRIJ-35 81

Figura 39: (A) Espectros de emissão do oxi-monômero de G.paulistus em tampão Tris- $\mathrm{HCl} 20 \mathrm{mmol} \mathrm{L}^{-1}(\mathrm{pH} 9,0), \lambda_{\mathrm{exc}}=295 \mathrm{~nm}$ em função da concentração de BRIJ35, (B) espécies puras: oxi-monômero puro (- $\mathbf{\Lambda}-)$ - espécie 1, complexo

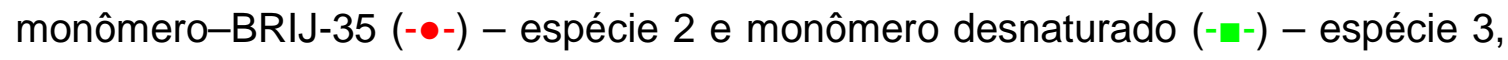
correspondentes aos componentes dos espectros experimentais presentes em diferentes proporções; (C) conteúdo relativo de cada espécie em função da concentração de BRIJ-35. 82

Figura 40: Espectros de dicroísmo circular do oxi-monômero de G. paulistus em tampão Tris-HCl $20 \mathrm{mmol} \mathrm{L}^{-1}(\mathrm{pH}$ 7,0) em função da concentração de: (A) BRIJ35; (B) CTAC; (C) SDS 85

Figura 41: Espectros de dicroísmo circular do oxi-monômero de G. paulistus em tampão Tris-HCl $20 \mathrm{mmol} \mathrm{L}^{-1}$ (pH 9,0) em função da concentração de: (A) BRIJ35; (B) CTAC; (C) SDS 86 
ÍNDICE DE TABELAS

Tabela 1 - Constantes de velocidade de auto-oxidação em meio alcalino para hemoglobinas e mioglobinas... 


\section{LISTA DE ABREVIATURAS E SÍMBOLOS}

HbGp - Hemoglobina de Glossoscolex paulistus

$\mathrm{Hb}$ - Hemoglobina

$\mathrm{Mb}$ - Mioglobina

DesoxiHb - Desoxi-hemoglobina

$\mathrm{OxiHb}$ - Oxihemoglobina

HBLt - Lumbricus terrestris

G. paulistus - Glossoscolex paulistus

TRIS-HCl - Cloridrato de hidroximetilaminometano

EDTA - Ácido etilenodiamino tetraacético

TRP - Triptofano

$\mathrm{Gb}$ - Globina

$\mathrm{K}_{\mathrm{obs}}$ - Constante de velocidade observada

CTAC - Cloreto de Cetiltrimetilamônio

SDS - Dodecil sulfato de sódio

BRIJ-35 - Polioxietileno Lauril Éter

$\mathrm{RQ}$ - Rendimento Quântico

HPLC-RP - Cromatografia Líquida de Alta Eficiência de Fase Reversa 


\section{RESUMO}

A hemoglobina $(\mathrm{Hb})$ do anelídeo Glossoscolex paulistus é uma $\mathrm{Hb}$ extracelular gigante. Esta é constituída por quatro cadeias polipeptídicas $a, b, c$ e $d$ contendo o heme. As cadeias $a, b$ e $c$ formam um trímero mantido por ligações dissulfeto e a cadeia $d$ é um monômero. Neste trabalho, as técnicas espectroscópicas de absorção ótica no UV-Vís, fluorescência e dicroísmo circular foram utilizadas para monitorar as mudanças produzidas na estrutura do monômero $d$ na forma oxi da hemoglobina extracelular gigante de Glossoscolex paulistus (HbGp) em pH 7,0 e 9,0 devido à interação com surfactantes iônicos, dodecil sulfato de sódio (SDS), cloreto de cetiltrimetilamônio (CTAC) e neutro, polioxietileno lauril éter (BRIJ - 35). A interação entre surfactantes e proteínas globulares tem sido estudada através de uma variedade de técnicas espectroscópicas visando à obtenção de informações relevantes com respeito à relação estrutura-atividade das proteínas. Os resultados de fluorescência mostraram que na presença dos surfactantes, há um aumento do rendimento quântico, sendo que o maior aumento é verificado na interação com o surfactante catiônico CTAC, sugerindo que a proteína apresenta uma quantidade maior de sítios específicos carregados negativamente, como os resíduos aniônicos, glutamil e aspartil. $\mathrm{Na}$ interação do monômero $d$ da HbGp com CTAC ocorreu a formação de espécie pentacoordenada em ambos os pHs. Para o sistema monômero da HbGp-SDS em pH 7,0 e 9,0, foi observada a oxidação do monômero $d$, caracterizada pela formação da espécie hemicromo. A interação do monômero $d$ em pH 7,0 e 9,0 com CTAC, analisada pelos espectros de dicroísmo circular, indicaram uma perda não muito significativa da estrutura secundária. No entanto, para os surfactantes SDS e BRIJ-35 foi possível constatar uma perda menos acentuada em relação ao CTAC. 


\begin{abstract}
The annelid hemoglobin $(\mathrm{Hb})$ of the Glossoscolex paulistus is a giant extracellular hemoglobin ( $\mathrm{Hb}$ ). It is constituted by four polypeptide $a, b, c$ and $d$ chains containing the heme. The chains $a, b$ and $c$ form a trimer maintained by disulfide bond and the $d$ chain is a monomer. In this work, the spectroscopic techniques of UV-Vís optical absorption, fluorescence and circular dichroism were used to monitor the changes induced by ionic detergents sodium dodecyl sulphate (SDS), cetyltrimethylammonium chloride (CTAC) and neutral, ether lauryl polioxitelene (BRIJ-35) in the structure of the $d$ monomer in the oxi form of the giant extracellular hemoglobin of Glossoscolex paulistus ( $\mathrm{HbGp}$ ) in $\mathrm{pH} 7.0$ and 9.0. The interaction between surfactants and globular proteins has been studied through a range of spectroscopic techniques targeting the obtaining of prominent information with regard to the relation structure-activity of the proteins. The fluorescence results showed that in the presence of the surfactants a quantum yield increases, and the CTAC promoted the more significant effect, suggesting that the protein presents a larger quantity of specific negative sites, as the anionic residues, glutamil and aspartil. In the interaction of $d$ monomer of the $\mathrm{HbGp}$ with CTAC occurred the formation of pentacoordinated species in both pHs. For system monomer of HbGp-SDS at $\mathrm{pH} 7.0$ and 9.0, was observed by oxidation of $d$ monomer, characterized by the formation of the species hemichrome. The interaction of $d$ monomer at $\mathrm{pH} 7.0$ and 9.0 with CTAC, analyzed by circular dichroism spectra, indicates the loss of secondary structure. However, for SDS and BRIJ-35 surfactants it is possible to detect the lower loss of secondary structure in relation to CTAC.
\end{abstract}




\section{INTRODUÇÃO}

\subsection{Hemoglobinas}

Comuns nos seres vivos, as hemoglobinas $(\mathrm{Hb})$ têm papel importante na manutenção da vida e no desenvolvimento da ciência. Nos organismos superiores, a ausência de um transportador de oxigênio tornaria a vida impossível, uma vez que o oxigênio é fundamental na produção de energia através do metabolismo da forma mais rentável ao organismo. Na ciência, o estudo das Hbs permitiu grande avanço no conhecimento e entendimento da relação entre estrutura e atividade de proteínas.

A $\mathrm{Hb}$ de mamíferos possui um arranjo tetraédrico e é constituída de quatro cadeias polipeptídicas, duas cadeias $\alpha$ e duas cadeias $\beta$ mantidas na forma oligomérica por interações eletrostáticas.

A Hb de mamíferos encontra se nas hemácias, isto é, intracelular. A sua função é transportar oxigênio do pulmão para os tecidos e dióxido de carbono dos tecidos para o pulmão. Nos tecidos ocorre a liberação do oxigênio, devido à baixas pressões de $\mathrm{O}_{2}\left(\mathrm{pO}_{2} \approx 20\right.$ torrs $)$, que diminuem a afinidade da $\mathrm{Hb}$ pelo gás. Nos pulmões, as altas pressões de $\mathrm{O}_{2}\left(\mathrm{pO}_{2} \approx 100\right.$ torrs $)$ saturam a $\mathrm{Hb}$ rapidamente.

O arranjo oligomérico confere à hemoglobina uma outra característica importante - a cooperatividade. A coordenação do $\mathrm{O}_{2}$ ao heme de uma das cadeias facilita a coordenação de outra molécula de $\mathrm{O}_{2}$ com outro heme do mesmo tetrâmero. A recíproca é verdadeira, ou seja, a saída desta molécula de 
$\mathrm{O}_{2}$ de um heme facilita a saída das moléculas de $\mathrm{O}_{2}$ dos outros hemes (Stryer, 1988) (Dickerson e Geys, 1983). O armazenamento do oxigênio é realizado pela mioglobina (Mb) que está distribuída no músculo. A Mb é um monômero, ou seja, constitui-se de uma única subunidade, não apresentando portanto, a cooperatividade. Assim, enquanto que a curva de saturação, ou seja, de ligação de $\mathrm{O}_{2}$ na mioglobina é uma função hiperbólica em relação à pressão de $\mathrm{O}_{2}$, da hemoglobina é uma sigmóide, isto é, a ligação de oxigênio à mioglobina pode ser descrita como um equilíbrio simples. Entretanto, a cooperatividade da hemoglobina proporciona um transporte de oxigênio mais eficiente, capaz de ligar cerca de 1,8 vezes mais oxigênio do que se as cadeias fossem independentes (Drew et al. 2002). Por outro lado, enquanto que 50\% de saturação da hemoglobina ocorre à $\mathrm{pO}_{2}$ de 26 torr, para a mioglobina ocorre sob uma $\mathrm{pO}_{2}$ de 10 torr, facilitando o suprimento de $\mathrm{O}_{2}$ nos tecidos.

O grupo responsável pela ligação de $\mathrm{O}_{2}$ é o grupamento heme (Figura 1) que é encontrado no interior do enovelamento de cada cadeia polipeptídica da Hb. O heme, que é grupo prostético, consiste de quatro anéis pirrólicos essencialmente coplanares, ligados entre si através de uma ponte de metina. A cada um dos anéis III e IV está ligado um grupo propionato e uma metila e em cada um dos anéis I e II está ligado um grupo eteno e uma metila. Os átomos de nitrogênio dos anéis pirrólicos estão orientados para o centro da estrutura sendo responsáveis pela coordenação de um íon de ferro central e o oxigênio coordena-se somente quando o ferro encontra-se com o estado de oxidação $2+$ (Stryer, 1988). 


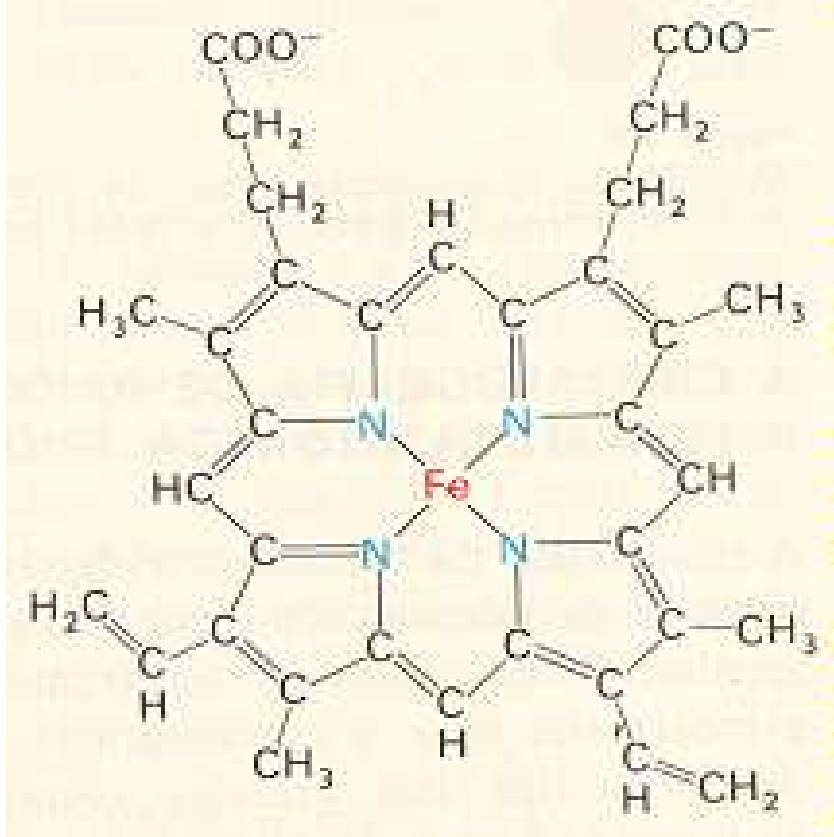

Figura 1 - Representação do grupo heme, que é um componente essencial em hemoglobinas, citocromos e enzimas como catalases e peroxidases. (Stryer, 1988).

A vizinhança do grupo heme nas hemoglobinas em geral é constituída de resíduos de aminoácidos não polares com exceção de duas histidinas, a distal (E7, sétimo resíduo da hélice E) e a proximal (F8, oitavo resíduo da hélice F) (Figura 2). 


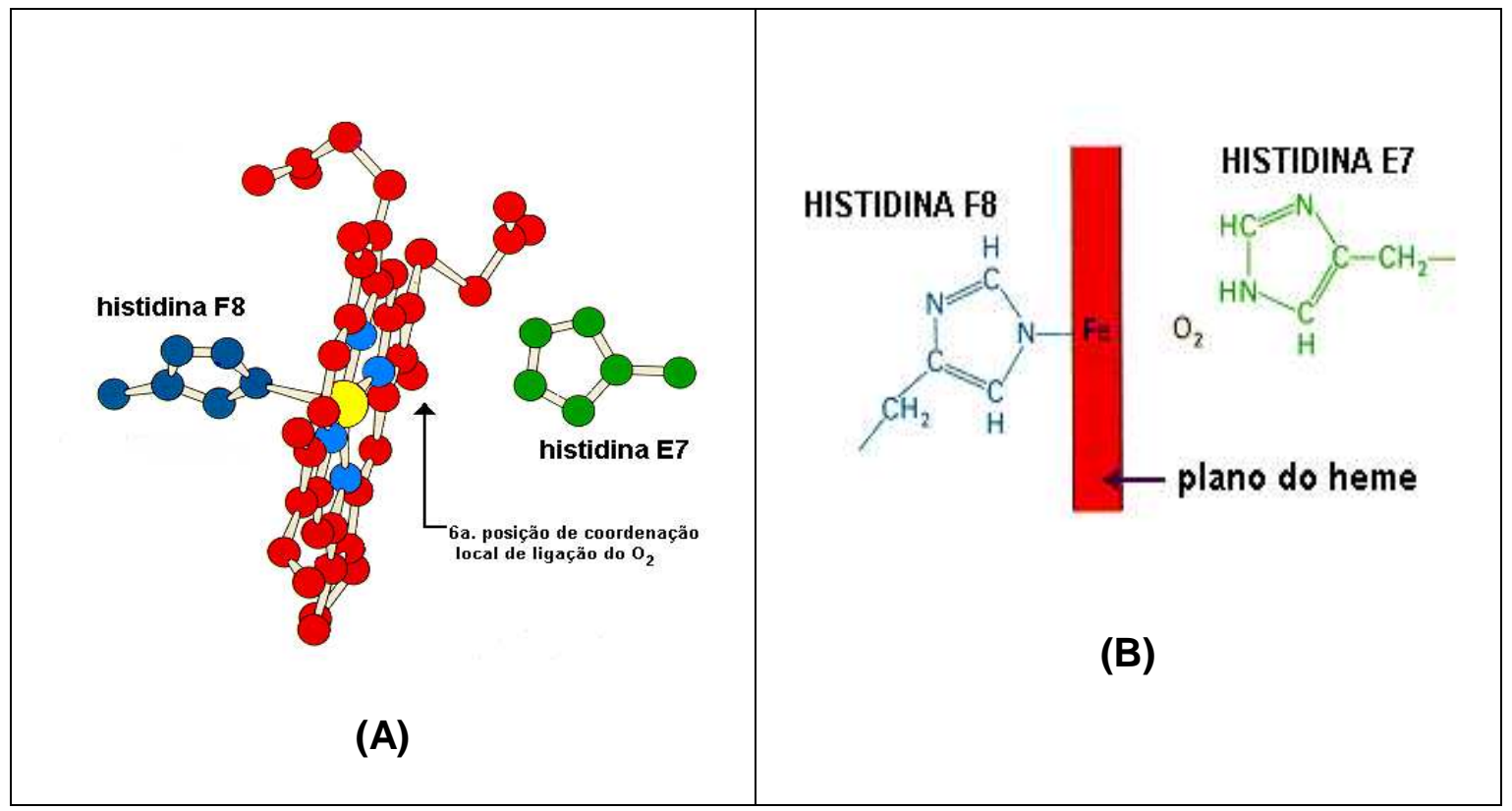

Figura 2 - Grupo heme, sua proximidade com as histidinas F8 e E7 e o local de ligação da molécula de $\mathrm{O}_{2}$ : (A) vista espacial; (B) vista lateral (Stryer, 1988).

Desta forma, tanto a hemoglobina como a mioglobina desempenham suas respectivas funções fisiológicas com o centro metálico no estado ferroso, isto é, no estado de oxidação $2^{+}$. Há seis sítios de coordenação ao redor do íon ferroso, em função do centro de coordenação Fe(II) apresentar uma configuração eletrônica $d^{6}$. Destes seis sítios de coordenação, quatro sítios estão coordenados a átomos de nitrogênio pirrólicos do anel porfírinico.

A porfirina é um ligante macrocíclico tetradentado, pois coordena o metal através de quatro sítios de ligação. O fato de ser tetradentado está relacionado com representativa estabilidade termodinâmica dos compostos de coordenação porfirínicos, tanto do ponto de vista entrópico como do ponto de vista entálpico. Esta estabilidade peculiar a ligantes volumosos vem sendo chamada de "efeito 
macrocíclico" e é bastante comum aos ligantes tetraazamacrocíclicos (Moreira, 2004).

A quinta posição de coordenação do heme é ocupada pelo átomo de nitrogênio de um imidazol, oriundo do grupo lateral da histidina proximal, sobre o qual o heme se apóia na proteína. Portanto, o imidazol da histidina proximal é o ligante endógeno responsável pela ligação entre o grupamento prostético e a cadeia polipeptídica. O sexto sítio de coordenação está disponível para ligar-se a um ligante exógeno, podendo alterar o estado de spin do centro de coordenação, e até mesmo favorecer a modificação do estado de oxidação do metal.

O íon ferroso, que se encontra fora do plano do heme na desoxihemoglobina, move-se durante o processo de oxigenação em direção ao plano da porfirina para formar uma ligação forte com o oxigênio, restabelecendo a planaridade do heme (figura 2). Realmente, este fenômeno, que é fundamental para a cooperatividade das hemoglobinas, está relacionado a várias propriedades do heme.

Realmente, é bem conhecido na literatura que as várias mudanças conformacionais possíveis do anel porfirínico e suas conseqüentes alterações na combinação de orbitais moleculares, são responsáveis por propriedades redox e alterações em afinidades por ligantes em complexos ferro-porfirínicos modelos e hemoproteínas (Moreira, 2004).

Medidas de infravermelho e espectroscopia Mössbauer, claramente indicam que a conversão tanto da mioglobina como da hemoglobina para suas 
formas oxigenadas está associada a um rearranjo eletrônico. Isto pode ser descrito por uma representativa doação $\pi$ (transferência de carga) do $\mathrm{Fe}(\mathrm{II})$ para $\circ \mathrm{O}_{2}$ e uma doação $\sigma$ (coordenação) do $\mathrm{O}_{2}$ para $\circ \mathrm{Fe}(\mathrm{II})$, resultando na forte ligação covalente entre o ferro e o oxigênio (Shikama, 1998).

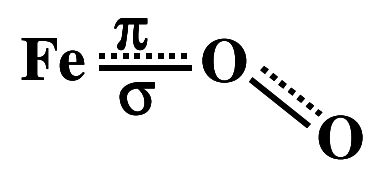

No caso fisiológico, a histidina E7, denominada distal, está voltada à sexta coordenação do ferro, estabilizando a ligação $\mathrm{Fe}-\mathrm{O}_{2}$ (figura 3) pela formação de uma ligação de hidrogênio entre o grupo $\mathrm{NH}$ do imidazol e o oxigênio molecular.

Realmente, o próton proveniente da histidina distal, efetivando uma ligação de hidrogênio com o oxigênio molecular coordenado ao centro ferroso, deve gerar um efeito indutivo sobre o ligante oxigênio, acentuando as propriedades eletrofílicas deste ligante. Esta influência torna o oxigênio mais apto para "retirar" densidade eletrônica do centro de coordenação do heme.

É conhecido na literatura que a ligação de hidrogênio entre a histidina distal e o oxigênio molecular coordenado como sexto ligante do centro ferroso seria um fator decisivo para a ligação de oxigênio nas hemoproteínas. Isto ocorre porque a ligação de hidrogênio em questão estabilizaria significativamente os orbitais $\pi^{\star}$ do oxigênio molecular, acentuando seu caráter 
ácido $\pi$ e a conseqüente retrodoação dos orbitais de simetria $\pi$ do ferro, $d_{x z} \mathrm{e}$ $d_{y z}$, para estes orbitais semi-preenchidos do oxigênio.

Portanto, a estabilização dos orbitais $\pi^{\star}$ torna o oxigênio um ligante viável para as hemoglobinas, ou seja, um ligante com afinidade pelo centro ferroso suficiente para competir por essa coordenação.

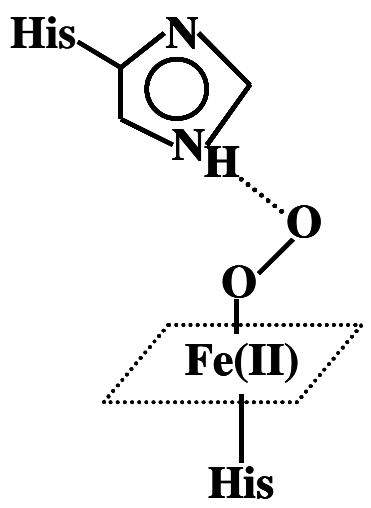

Figura 3 - Representação da histidina E7, distal, proporcionando estabilidade à ligação $\mathrm{Fe}-\mathrm{O}_{2}$ através da formação de uma ligação de hidrogênio entre o NH do imidazol e o oxigênio molecular.

\subsection{Hemoglobinas Extracelulares Gigantes}

As hemoglobinas extracelulares gigantes, também chamadas eritrocruorinas, são hemoproteínas interessantes devido à massa molecular elevada e à estrutura oligomérica, que envolve um grande número de subunidades. O filo anelídeo compreende mais de oito mil espécies, subdivididas em aquáticas, terrestres e marinhas. A maioria dos anelídeos possui hemoglobinas extracelulares e intracelulares (Lamy, 1996). 
A hemoglobina do anelídeo Lumbricus terrestris (HBLt) tem sido muito estudada, sendo que a disposição de suas subunidades no arranjo oligomérico ainda permanece controversa (Daniel, 2004). Segundo os dados mais aceitos, esta hemoglobina é formada por 144 globinas e 36 cadeias estabilizadoras chamadas "linkers", que são cruciais para a sua integridade estrutural (Royer, 2000) (Zal, 2000).

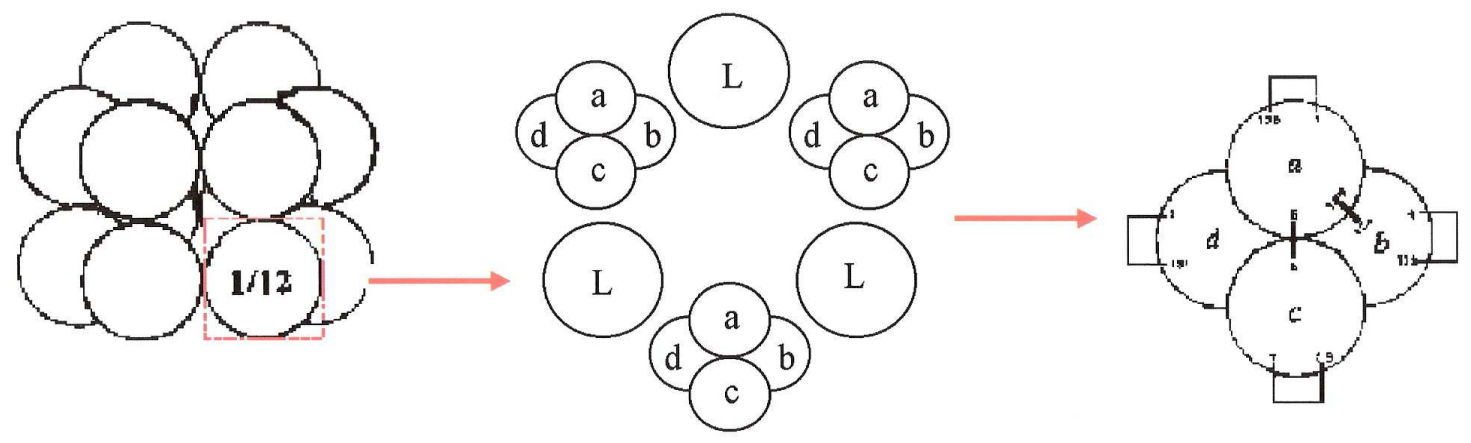

Figura 4 - Representação esquemática da hemoglobina de HBLt.

As cadeias da HbLt estão dispostas como dois discos hexagonais sobrepostos, apresentando as subunidades $a, b, c$ e $d$, que contém grupos heme, nos vértices dos hexágonos e as subunidades "linkers" ou cadeias "L", que não apresentam grupamentos heme, na parte central do arranjo supramolecular (Royer, 2001). As subunidades estão arranjadas como doze dodecâmeros, sendo que cada um deles é constituído por três tetrâmeros. Portanto, o dodecâmero consiste de três trímeros (figura 4), que são cadeias monoméricas $a, b, c$ ligadas por ligações de dissulfeto, e três cadeias monoméricas $d$ (Haas, 1997) (Royer, 2001). 
Em suma, a HbLt se apresenta como uma bicamada hexagonal, sendo que sua estrutura quaternária é chamada de "modelo do bracelete" (figura 5). Esta arquitetura oligomérica é suportada por microscopia crioeletrônica (Krebs, 1996) (Green, 2004) (Yamaki, 1998).

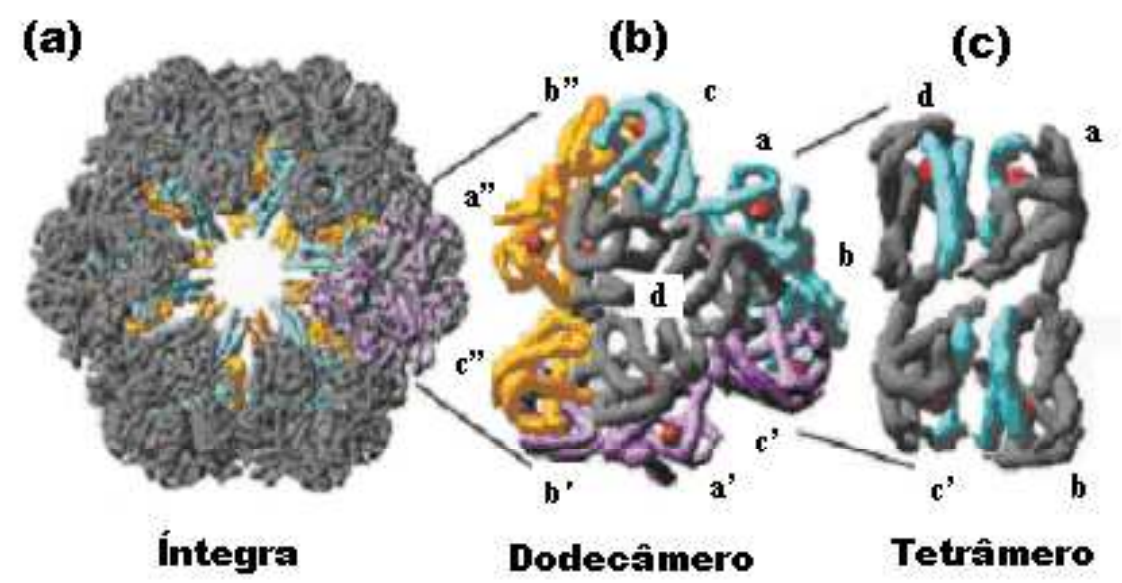

Figura 5 - Modelos dos arranjos espaciais da hemoglobina íntegra, do dodecâmero e do tetrâmero de Lumbricus terrestris (Royer, 2001).

As hemoglobinas gigantes extracelulares possuem alta cooperatividade na ligação com o oxigênio molecular (Madura, 2002) (Krebs, 1996) e apresentam um ponto isoelétrico abaixo de 7. Suas cadeias linkers, que são subunidades com função estrutural e sem grupamento prostético, possuem um ponto isoelétrico entre pH 4,7 e 5,6 (Kuchumov, 1998). Além disso, constituem sistemas significativamente auto-organizáveis, como demonstram estudos envolvendo reassociação das cadeias (Zhu, 1996) (Kuchumov, 1998). 
Segundo Vinogradov (Vinogradov, 2004), as hemoglobinas extracelulares gigantes representam o ápice de complexidade das hemoproteínas que ligam oxigênio. Estas hemoglobinas são sistemas supramoleculares muito intrigantes, inclusive, sob o aspecto da seleção natural, uma vez que demonstram propriedades de adaptação não triviais em meios ricos em sulfetos (Bailly, 2005) (Zal, 2000).

A título de ilustração das potencialidades deste sistema protéico é interessante mencionar que a hemoglobina de Lumbricus terrestris vem sendo aplicada em pesquisas de sangue artifical (Dorman, 2004) (Hirsch, 1997). Strand e colaboradores (Strand, 2004) afirmam que as eritrocruorinas têm sido sugeridas como sistemas modelos de substitutos terapêuticos do sangue devido à sua natureza extracelular, grande tamanho e resistência à oxidação. Realmente, essa hemoglobina extracelular, quando em seu estado íntegro, apresenta estabilidades estrutural e redox (Dorman, 2004) (Madura, 2002) significativamente maiores do que as hemoglobinas intracelulares, como por exemplo, a hemoglobina humana, o que não deixa de tornar a avaliação dos fatores que controlam esse comportamento altamente relevante não só para o estudo desta hemoglobina gigante, como igualmente, para proporcionar um melhor entendimento das hemoglobinas em geral.

Para um estudo detalhado das partes constituintes da hemoglobina, duas condições diferentes de dissociação têm sido empregadas: o meio alcalino e a incubação em uréia a 4 M em pH 7. A dissociação em pH 9.3 da HbLt permite isolar o trímero abc e o monômero d. A dissociação da HbLt com uréia $4 \mathrm{M} \mathrm{pH} \mathrm{7,}$ 
seguida por cromatografia de filtração em gel, produz uma fração de massa molecular $200 \mathrm{KDa}$ que tem sido associada à espécie $(a b c d)_{3}$ (Lamy, 1996).

No trabalho sobre auto-oxidação da hemoglobina de Perinereis brevicirris, realizado por Suzuki (Suzuki, 1983), observa-se que a velocidade de auto-oxidação da hemoglobina de invertebrados é mais de dez vezes menor que a velocidade de auto-oxidação da hemoglobina de vertebrados. Isto ocorre em função da estrutura altamente organizada das hemoglobinas de invertebrados proteger a molécula contra a auto-oxidação. O valor da energia de ativação para a reação de auto-oxidação da hemoglobina de Perinereis brevicirris é próximo ao valor para a mioglobina bovina, sugerindo que o mecanismo de auto-oxidação é semelhante àquele mecanismo pertinente às mioglobinas de vertebrados.

Também é constatado que a presença de cátions divalentes como $\mathrm{Ba}$ (II), Ca (II), Sr (II) e Mg (II) inibem o processo de auto-oxidação na hemoglobina de Lumbricus terrestris, diminuindo a velocidade da reação. Isto ocorre porque esses cátions divalentes produzem um grande efeito na ligação do oxigênio. A função destes cátions na estabilização da forma oxi-hemoglobina de Lumbricus terrestris consiste em evitar a dissociação do oxigênio, que é geralmente a primeira etapa para a formação da meta-hemoglobina. Além disso, estes cátions também evitam a dissociação da proteína em subunidades (Harrington, 1994). 


\subsection{Hemoglobina extracelular de Glossoscolex paulistus.}

O anelídeo Glossoscolex paulistus pertence ao filo Anelidae, à classe Oligochaeta e à família Glossoscolecidae (Tinto, 1994) (Fernandez, 2001). Este animal apresenta um comprimento que varia de 280 a 305 milímetros e o seu maior diâmetro, na região mediana do corpo, alcança de 10 a 11 milímetros (figura 6) (Righi, 1972])

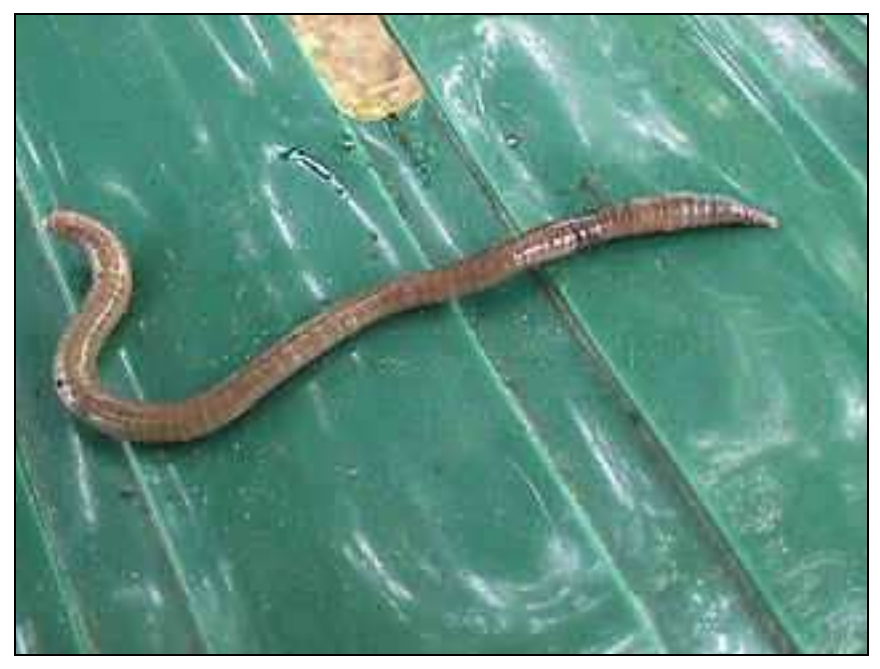

Figura 6 - Foto do anelídeo G. paulistus, conhecido popularmente como minhocoçu

Esta minhoca de tamanho expressivo, conhecida popularmente como minhocoçu, é encontrada em determinados sítios das cidades de Piracicaba, Araras e Rio Claro, no estado de São Paulo, Brasil (Righi, 1972). Tais localidades apresentam solos superficiais calcários que favorecem o desenvolvimento deste anelídeo (Tinto, 1994). Animais da mesma classe da espécie G. paulistus, como, por exemplo, a espécie Lumbricus terrestris, vêm 
sendo empregados em vários estudos ecológicos de solos em função de suas ações de reciclagem de nutrientes e de dinâmica de solos (Rossi, 2004), que são ações extremamente úteis à fertilidade do solo.

A hemoglobina extracelular gigante do anelídeo G. paulistus faz parte da classe das hemoglobinas conhecidas como HBL (que são as iniciais de "Hexagonal Bilayer Hemoglobins", ou seja, Hemoglobinas de Bicamada Hexagonal), que possui propriedades muito semelhantes às hemoglobinas de outros invertebrados.

A massa molecular da hemoglobina extracelular gigante de G. paulistus foi determinada pela medida do coeficiente de sedimentação (Costa, 1988). Além disso, dentre os estudos realizados com hemoglobina de G. paulistus destacam-se a caracterização de ligações dissulfeto (Meireles, 1985), a dissociação por pressão hidrostática (Silva, 1989), a reassociação por fatores não protéicos como cálcio e glicerol (Bonafe, 1991), a caracterização das subunidades e a determinação da massa molecular por eletroforese e filtração em gel, além de estudos de dissociação através da variação do $\mathrm{pH}$, acompanhados por fluorescência tanto para a hemoglobina ferrosa íntegra (Tinto, 1994) como para a hemoglobina férrica íntegra (Agustinho, 1995). Vale destacar os estudos espectroscópicos das interações da hemoglobina com detergentes iônicos (Gelamo, 1999), assim como estudos envolvendo a cadeia monomérica $d$ da $\mathrm{HbGp}$, que teve a sua estrutura primária determinada, sendo realizada, inclusive, a modelagem molecular da mesma (Cabral, 2002). 
Portanto, a hemoglobina de G. paulistus é uma hemoproteína gigante que contém um número elevado de grupos heme, que representam as unidades não polipeptídicas denominadas grupamentos prostéticos. A unidade protéica denominada globina (Gb) ou apo-hemoglobina apresenta cadeias polipeptídicas tanto na forma de trímero, estabilizadas por ligações dissulfeto, como na forma de monômero $d$, na hemoglobina.

A estrutura oligomérica da oxi-hemoglobina de $G$. paulçistus em $\mathrm{pH}$ alcalino foi estudada por Imasato e colaboradores (Imasato, 1995). Os resultados experimentais mostram que, em pH 9, ocorre dissociação da espécie oxi-hemoglobina em dímeros de tetrâmeros $(a b c d)_{2}$, trímeros $a b c$, monômeros $d$ e cadeias linkers (Imasato, 1995). Estudos da hemoglobina na forma oxidada $\left(\mathrm{Fe}^{+3}\right)$ (Agustinho, 1997) demonstraram que esta espécie, em meio alcalino, sofre completa dissociação em trímeros e monômeros, sugerindo que a hemoglobina na forma oxidada é mais instável em relação ao arranjo oligomérico quando comparada com a espécie oxi-hemoglobina, isto é, que a oxidação da proteína favorece a sua dissociação protéica.

Zhu e colaboradores (Zhu, 1996) estudaram a estrutura oligomérica da hemoglobina de Lumbricus terrestris e também observaram que a associação e a dissociação das subunidades dependem do estado de oxidação. Particularmente, a oxidação do complexo $(a b c d)_{4}$ com ferricianeto causa completa dissociação em monômeros $d$ e trímeros $a b c$, mas a adição de $\mathrm{CN}^{-}$ mantém o complexo $(a b c d)_{4}$ ou reassocia as subunidades oxidadas. Esta constatação ressalta a ação efetiva do cianeto nas hemoglobinas gigantes, 
além de evidenciar a correlação entre as modificações do heme com as alterações das cadeias polipeptídicas propriamente consideradas.

Recentemente, Gelamo e colaboradores (Gelamo, 2004) mostraram claramente por SAXS (Espalhamento de raios-x a baixo ângulo), que os raios de giro tanto da oxi-hemoglobina como da meta-hemoglobina de G. paulistus diminuem de $110 \AA ̊$, em pH 7,0, para $31 \AA$, em pH 9,0, indicando a dissociação do complexo mesmo em concentrações mais altas, $3 \mathrm{mg} . \mathrm{ml}^{-1}\left(\sim 1 \times 10^{-4} \mathrm{~mol} \mathrm{~L}^{-1}\right)$. O arranjo das subunidades tem uma importante função na ligação de oxigênio para a hemoglobina humana (Ackers, 1992), pois estudos do efeito alostérico da hemoglobina humana indicam que a cooperatividade é mediada através da interação entre as subunidades.

Em resumo, os estados de organização da hemoglobina íntegra são dependentes tanto do estado de oxidação do centro de coordenação da porfirina como dos ligantes axiais (Riggs, 1998), o que está de acordo, inclusive, com trabalhos anteriores de nosso grupo envolvendo a hemoglobina de G. paulistus (Gelamo, 2003) (Gelamo, 2004) (Agustinho, 1997). Riggs e colaboradores (Riggs, 1998) propuseram que, em geral, hemoglobinas de invertebrados apresentam mudanças conformacionais dependentes dos ligantes, com mecanismos de cooperatividade diferentes daqueles encontrados nas hemoglobinas de vertebrados.

Através da dissociação em meio alcalino, empregando-se filtração em gel, foi possível a separação e a caracterização de suas partes constituintes por eletroforese. Foram estudadas as espécies coexistentes no equilíbrio da 
meta-hemoglobina íntegra d G. paulistus e do monômero $d$ separadamente, em função do pH. Notou-se que existe um equilíbrio em que predominam três espécies distintas em função do $\mathrm{pH}$ para a hemoglobina íntegra de $G$. paulistus.

$\mathrm{Na}$ faixa de $\mathrm{pH}$ entre 6,5 e 7,5, a espécie spin alto (aquometa-Hb) é favorecida, mas em valores de $\mathrm{pH}$ acima de 7,5 ocorre a formação do hemicromo, que consiste na coordenação da histidina distal ao centro metálico, gerando um complexo bis-histidina baixo spin (Moreira, 2005). Para valores de $\mathrm{pH}$ superiores a 10,5 uma nova espécie spin alto prevalece no equilíbrio, sendo que esta espécie perdeu um dos ligantes axiais, constituindo-se em uma espécie pentacoordenada (Moreira, 2005).

Em meio ácido, a sequência de formação de espécies é semelhante ao meio alcalino, envolvendo a mesma transição entre as espécies aquometahemicromo-pentacoordenado, conforme o valor de $\mathrm{pH}$ é afastado da neutralidade. De fato, neste meio, a transição entre as espécies aquometa e hemicromo é mais gradual, ocorrendo esta transição em torno do $\mathrm{pH} 5,0$, ao passo que a transição entre hemicromo e a espécie pentacoordenada ocorreria abaixo do pH 4,0 (Moreira, 2005).

Portanto, a proteína íntegra, tanto em meio ácido como em meio alcalino, na forma meta, apresenta um equilíbrio simplicado semelhante ao esquema a seguir: 


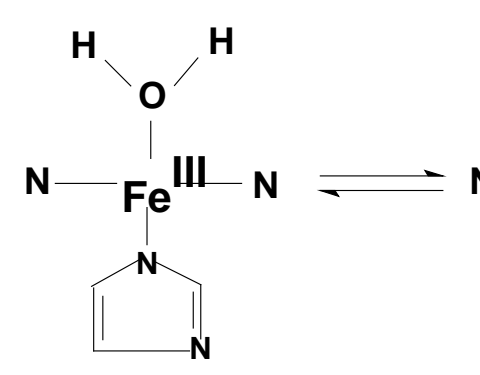

Aquometa

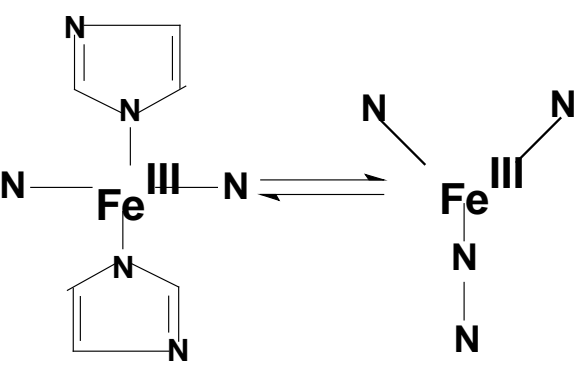

Hemicromo Pentacoordenado

Figura 7 - Representação das três principais espécies presentes tanto em meio alcalino como em meio ácido (Moreira, 2005).

O comportamento de hemoproteínas submetidas à variação de $\mathrm{pH}$ não é considerado trivial justamente em função da complexidade do equilíbrio formado (Morikis, 1989) (Dasgupta, 1989). Realmente, há na literatura artigos que enfatizam que as hemoglobinas especificamente, além das hemoproteínas em geral, apresentam um equilíbrio químico complexo (Levy, 1990) (Wajnberg, 1996) (Trent III, 2001) (Dasgupta, 1989), com concentrações diferentes de cada espécie, dependendo de cada $\mathrm{pH}$, inclusive, com a coexistência de espécies pentacoordenadas e hexacoordenadas (Trent III, 2001) (Dasgupta, 1989).

Com relação especificamente ao fenômeno da auto-oxidação, a hemoglobina extracelular gigante de G. paulistus apresenta um comportamento realmente interessante do ponto de vista de sua relação estrutura-atividade. Em estudo anterior (Leves, 2001) (Poli, 2005), o processo de auto-oxidação é estudado em pH 9,0, onde a hemoglobina já se encontra dissociada em tetrâmeros, trímeros e monômeros (Imasato, 1995), permitindo a avaliação, em experimentos independentes, da auto-oxidação da proteína íntegra e da 
subunidade monomérica $d$ isolada. A cinética de auto-oxidação observada neste trabalho resulta em curvas bi-exponenciais para a hemoglobina íntegra, indicando a ocorrência de um processo rápido e de outro processo lento. Já para o monômero $d$, a cinética de auto-oxidação se apresenta monoexponencial de primeira ordem. Comparando os resultados do processo lento da hemoglobina íntegra com os resultados da auto-oxidação do monômero $d$, infere-se que a auto-oxidação monomérica corresponde à etapa lenta da autooxidação da hemoglobina íntegra.

Além disso, os componentes da HbGp apresentam constantes de autooxidação maiores que as constantes referentes às cadeias isoladas da hemoglobina humana (Tsuruga, 1998) e da oxi-mioglobina bovina (tabela 1). Suzuki e colaboradores (Suzuki, 1983) estabelecem que duas subunidades isoladas da hemoglobina extracelular de Perinereis brevicirris possuem constantes de auto-oxidação muito superiores à constante observada para a oxi-mioglobina bovina (Satoh, 1981) em meio alcalino. Portanto, neste trabalho de Suzuki e colaboradores (Suzuki, 1983) é constatado um comportamento semelhante àquele detectado para a HbGp. Por conseguinte, infere-se que os componentes da G. paulistus em meio alcalino evidenciam bolsões hidrofóbicos do heme mais acessíveis ao solvente do que os bolsões de hemoproteínas de mamíferos. 
Tabela 1 - Constantes de velocidade de auto-oxidação em meio alcalino para hemoglobinas e mioglobinas.

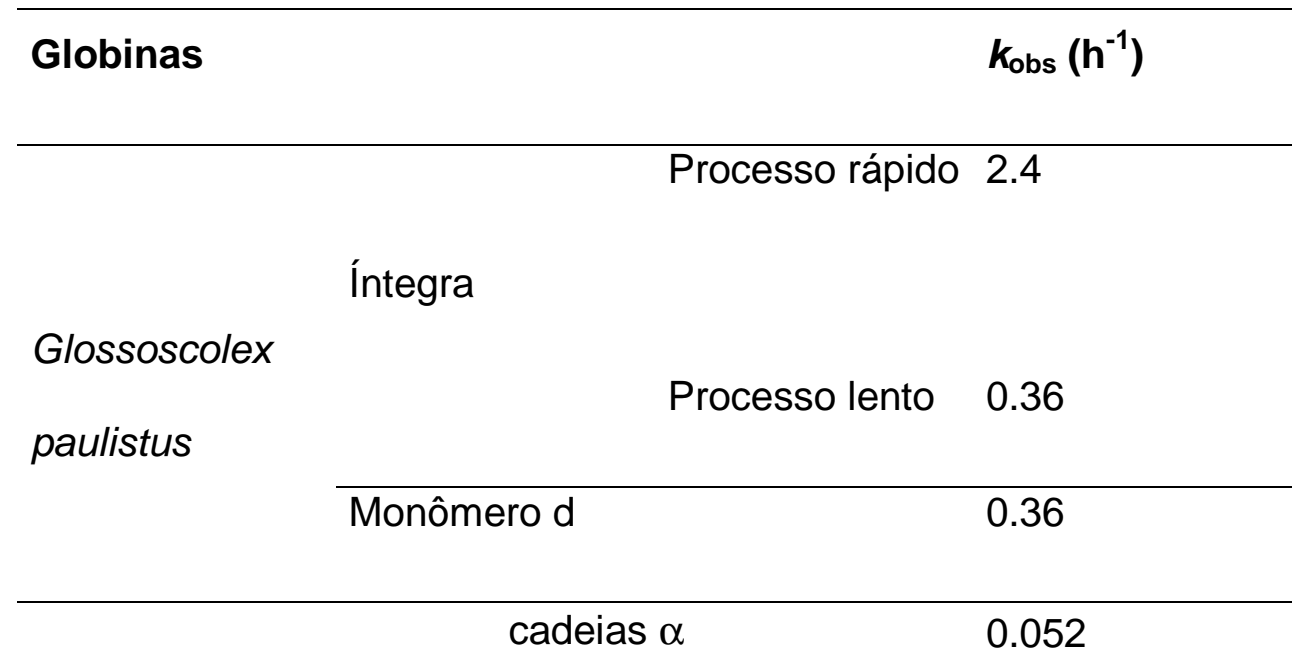

Hemoglobina humana

cadeias $\beta \quad 0.089$

Oxi-mioglobina Bovina $\quad 0.011$

Subunidade 1

Perinereis brevicirris

Subunidade $2 \quad 0.17$

A partir da obtenção, através de cálculos de homologia, do modelo do monômero $d$ (Cabral, 2002) (Figura 8), que apresentou 55\% de identidade estrutural em relação à cadeia monomérica $d$ de Lumbricus terrestris, estudouse o equilíbrio do monômero $d$ nativo e reconstituído em função do $\mathrm{pH}$, 
objetivando-se a compreensão mais ampla das propriedades dos mesmos (Ribelatto, 2005).

Para a fração monômérica $d$ nativa em valores de pH entre 7,0 e 10,0 predomina a espécie hemicromo baixo spin e em valores de $\mathrm{pH}$ acima de 10,0 a espécie alto spin pentacoordenada é favorecida (Ribelatto, 2006). Além disso, um comportamento semelhante foi observado para o monômero $d$ reconstituído, ou seja, as mesmas espécies são formadas em valores de pH similares. Isto sugere que a subunidade protéica $d$ teria significativa capacidade de autoorganização.

A seqüência de aminoácidos do monômero $d$ da HbGp foi determinada pela combinação de duas hidrólises enzimáticas nos grupos carbóxi de resíduos de lisina (endo-Lys-C) e de ácidos glutâmicos (endo-Glu-C). A seguir, foi efetuada a análise do terminal amínico da hemoglobina, assim como a separação e a purificação de peptídeos por RP-HPLC. Posteriormente, foi realizado o seqüenciamento de aminoácidos por degradação de Edman automatizada. A seqüência do monômero $d$ contém 142 resíduos e uma massa molecular calculada de $16212,37 \mathrm{Da}$.

O modelo proposto para a estrutura terciária apresentou $75,9 \%$ dos resíduos envolvidos em hélices $\alpha$, de acordo com a média esperada para hemoglobinas. Importante acrescentar que as hélices $\mathrm{E}$ e $\mathrm{F}$ apresentaram como resíduos distal e proximal o aminoácido histidina.

O modelo apresentou uma ponte dissulfeto entre as hélices $\mathrm{A}$ e $\mathrm{H}$, entre as cisteínas Cys 3 e Cys 132, como nas globinas constituintes de hemoglobinas 
extracelulares como Lumbricus terrestris, que também apresentam ligações dissulfeto.

O grupo heme encontra-se numa cavidade hidrofóbica, com os grupos propionatos orientados para o exterior da molécula, sendo estabilizados por pontes salinas entre os resíduos Arginina E9, Glutamina F7 e Arginina FG2.

O modelo (Figura 8) permitiu apreciação do ambiente hidrofóbico característico de hemoglobinas. A partir do cálculo de acessibilidade do solvente aos triptofanos, que se encontram no interior da molécula, foi encontrado um valor médio de $6,13 \%$, que é considerado baixo, consistente com o espectro de emissão do monômero $d$ cujo máximo de emissão ocorre em $320 \mathrm{~nm}$. Infere-se que os triptofanos se encontram em um meio de constante dielétrica baixa, o qual não é favorável para estabilizar o estado excitado que é polarizado. A posição de máximo da emissão do triptofano em meio aquoso é geralmente deslocada para $350 \mathrm{~nm}$. Até mesmo o apo-monômero apresenta o máximo de emissão em 320 nm, o que estaria relacionado ao fato da ligação SS- entre as cisteínas, localizadas nas hélices $\mathrm{A}$ e H, ser um importante fator para a manutenção do ambiente apolar que envolve os triptofanos (Cabral, 1999). 


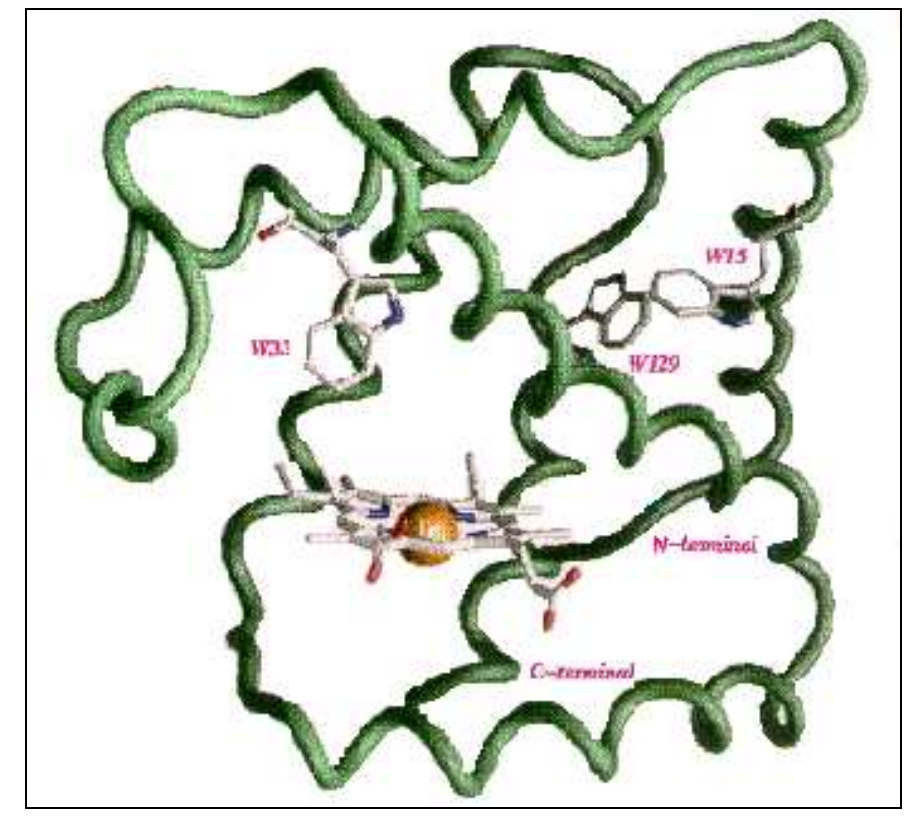

Figura 8 - Posições dos triptofanos no interior do modelo do monômero $d$ da hemoglobina de G. paulistus.

\subsection{Interação detergente-proteína}

Os detergentes, que são compostos anfifílicos solúveis, contêm um grupo apolar de natureza alifática ou aromática, e também possuem um grupo polar. A parte alifática é hidrofóbica, pouco solúvel em água e solúvel em muitos solventes apolares. Os grupos polares podem ser carregados, tais como os grupos fosfato, amino, sulfato e carboxil, ou neutros como os grupos hidroxila, carbonila e éster. Os grupos hidrofílicos são denominados de "cabeça" polar enquanto os hidrofóbicos são chamados de "cauda". As moléculas que possuem estes dois grupos são denominadas de anfifílicas (Helenius, 1975). Moléculas anfifílicas incluem sabões, detergentes e os próprios fosfolipídios que 
proporcionam a estrutura básica para as membranas biológicas (Helenius, 1975).

Os compostos anfifílicos agregam-se espontaneamente em presença de água. O tamanho e a forma do agregado dependem de vários fatores, entre eles, a natureza e o comprimento da cadeia apolar, a natureza do grupo polar, a concentração, a temperatura, a natureza do solvente e o método de preparação (Kalyanasundaram, 1987).

No interior da fase líquida, para baixas concentrações de surfactante em água, estes encontram-se na forma monomérica. Já em concentrações maiores que a concentração micelar crítica (cmc), os surfactantes formam agregados (micelas), onde a parte hidrofóbica destes monômeros geram contatos entre si, formando um agregado micelar, e a parte hidrofílica forma uma estrutura como uma concha em contato com o ambiente aquoso (Szabo, 1989). Em ambientes não aquosos podem ser formadas micelas reversas, ou seja, as cabeças polares conectam entre si no centro da micela e a cauda hidrofóbica forma a concha em contato com o solvente. Estas micelas podem ser pequenas esferas, elipsóides, cilindros longos, ou ainda, podem formar bicamadas, que são duas camadas paralelas de moléculas formando uma vesícula com a cavidade interna que pode estar preenchida ou não com solvente, dependendo da sua natureza hidrofílica ou hidrofóbica (Tanford, 1973).

Pode-se determinar a cmc através de vários métodos, sendo todos eles baseados nas mudanças das propriedades observadas na micelização, como tensão superficial, espalhamento clássico de luz, etc. Para alguns surfactantes, 
a cmc observada depende muito fortemente das condições experimentais como temperatura, pH, força iônica, presença de impurezas etc (Tanford, 1973).

Os surfactantes podem ser classificados segundo a carga da parte hidrofílica e tamanho ou natureza da cauda hidrofóbica. Com relação às cargas, os detergentes podem ser aniônicos, catiônicos, zwiteriônicos ou neutros. Na figura 1.9 está representada a estrutura do dodecil sulfato de sódio (SDS), Cloreto de Cetiltrimetilamônio (CTAC), e Polioxietileno Lauril Éter (BRIJ - 35).

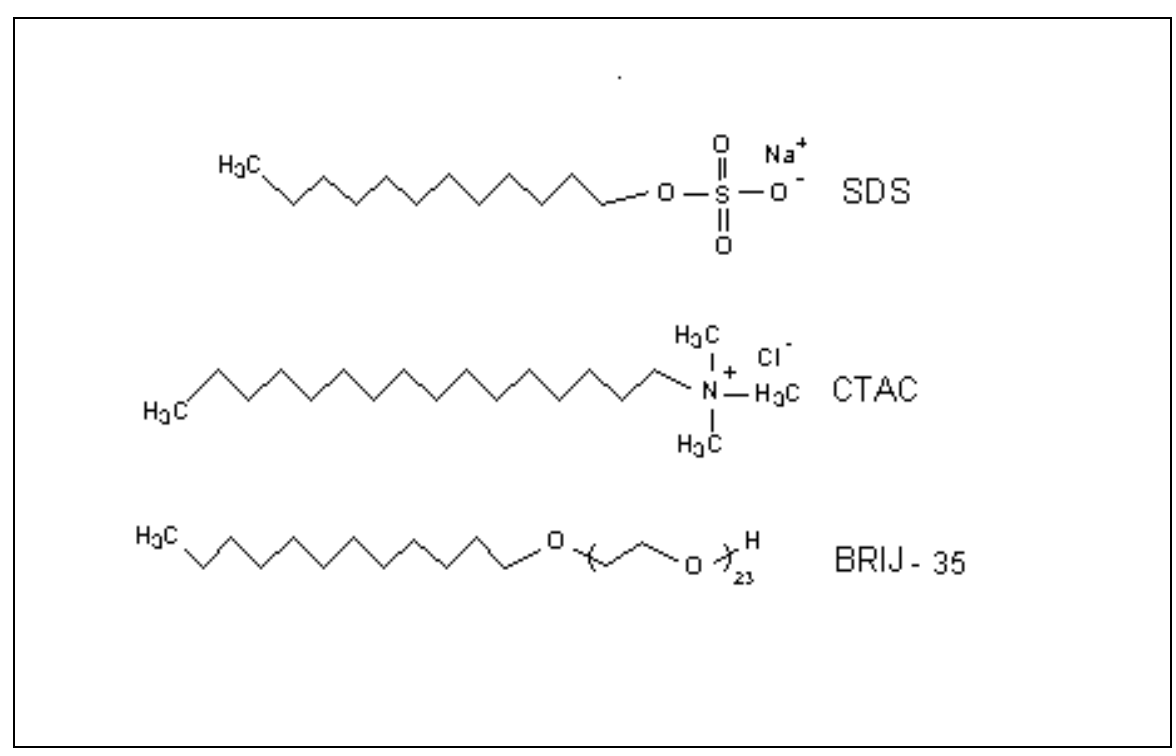

Figura 9 - Estrutura química dos surfactantes: aniônico: Dodecil Sulfato de Sódio (SDS); catiônico: Cloreto de Cetiltrimetilamônio (CTAC), e neutro: Polioxietileno Lauril Éter (BRIJ - 35).

O uso de detergentes em pesquisas nas áreas de biofísica e bioquímica é uma prática freqüente. Dentre as aplicações de detergentes, pode-se destacar o uso de dodecil sulfato de sódio (SDS) em eletroforese em gel de 
poliacrilamida (SDS-PAGE) para se determinar a composição polipeptídica e estimar a massa molecular de proteínas. Por ser um desnaturante poderoso, desenovela muitas proteínas em concentrações acima de sua cmc $(8 \mathrm{mM}$ em água). A estrutura terciária pode, eventualmente, ser perdida em função da interação com este surfactante aniônico e a amostra consistiria de polipeptídeos saturados de SDS, que se ligam à proteína na razão de 1,4-2,5g de SDS por grama de proteína (Jones, 1995).

A interação entre surfactantes e proteínas globulares tem sido estudada através de várias técnicas visando à obtenção de informações relevantes do ponto de vista da relação estrutura-atividade das proteínas. Dentre estes métodos, pode-se citar:

1. Eletroforese em gel de poliacrilamida objetivando-se detecção de complexos específicos;

2. Espalhamento de luz estático e dinâmico visando à obtenção de massas moleculares, coeficientes de difusão e dimensões dos complexos;

3. Espectroscopia de absorção na região do ultravioleta-visível para obtenção de dados sobre as modificações induzidas por surfactantes que ocorrem em toda a proteína, especialmente no heme;

4. Espectroscopia de emissão de fluorescência visando à obtenção parâmetros termodinâmicos dos complexos proteína-surfactante;

5. Espectroscopia de dicroísmo circular que proporciona a detecção de mudanças conformacionais produzidas na proteína, especialmente 
mudanças na estrutura secundária induzidas pela associação do surfactante;

6. Calorimetria (microcalorimetria e titulação calorimétrica) que fornece dados da entalpia da ligação de surfactantes na desnaturação da proteína;

7. Ultracentrifugação (razão de sedimentação e equilíbrio) que fornece coeficientes de sedimentação dos complexos de proteína-surfactante, dissociação de subunidades e massas moleculares.

Os surfactantes, em baixas concentrações, podem se ligar à proteína mantendo sua estrutura terciária intacta ou podem causar dissociação e/ou desnaturação. Comumente, os surfactantes aniônicos como SDS desnaturam proteínas, embora existam proteínas como glicose oxidase, papaína e pepsina que resistem à desnaturação por SDS sob determinadas condições.

Para surfactantes aniônicos, a ligação inicial ocorre nos sítios catiônicos da superfície da proteína, especificamente aos resíduos lisil, histidil e arginil, enquanto que para os surfactantes não iônicos, os sítios de ligação ocorrem nas partes hidrofóbicas da proteína. No caso dos surfactantes catiônicos, esta ligação acontece nos resíduos glutamil e aspartil (Szabo, 1989).

Os surfactantes aniônicos podem, entretanto, induzir a desnaturação da proteína e, assim, expor mais os sítios hidrofóbicos localizados no interior da mesma. O modelo mais geral da interação entre o surfactante e a proteína está apresentado na figura 10 . 


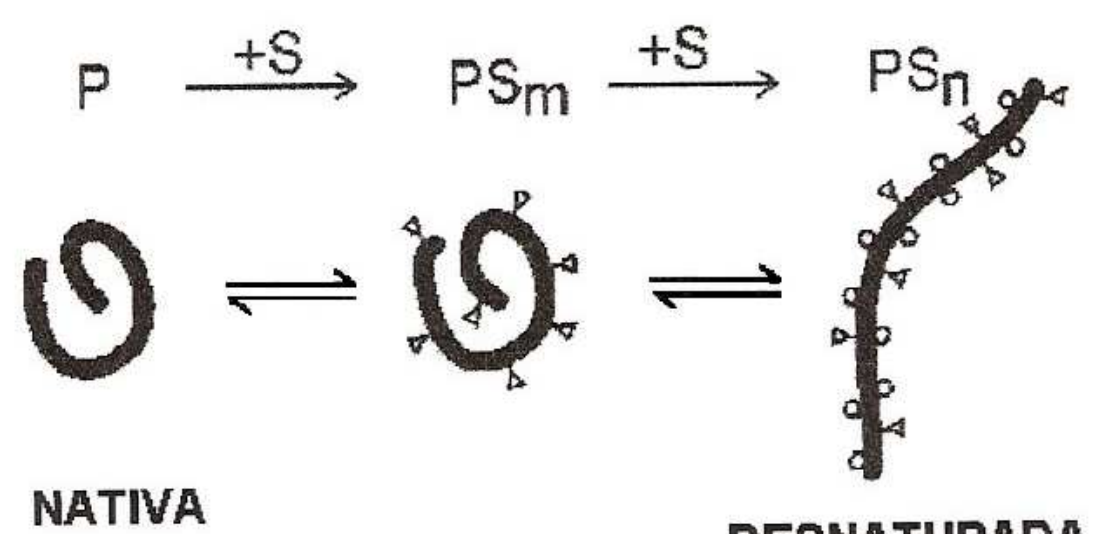

DESNATURADA

Figura 10 - Representação esquemática da ligação do surfactante à proteína nativa $(P)$ e o subseqüente processo de desnaturação.

É interessante destacar que a desnaturação acontece para uma concentração muito menor de surfactante do que a concentração necessária de desnaturantes comumente utilizados tais como uréia (6-8 M) e guanidina (4-6 M).

Embora não se conheça completamente a estrutura dos complexos proteína-detergente, têm-se utilizado algumas técnicas espectroscópicas e eletroforéticas para uma possível previsão desta estrutura. Basicamente, quatro modelos têm sido propostos e são apresentados na figura 11 . 


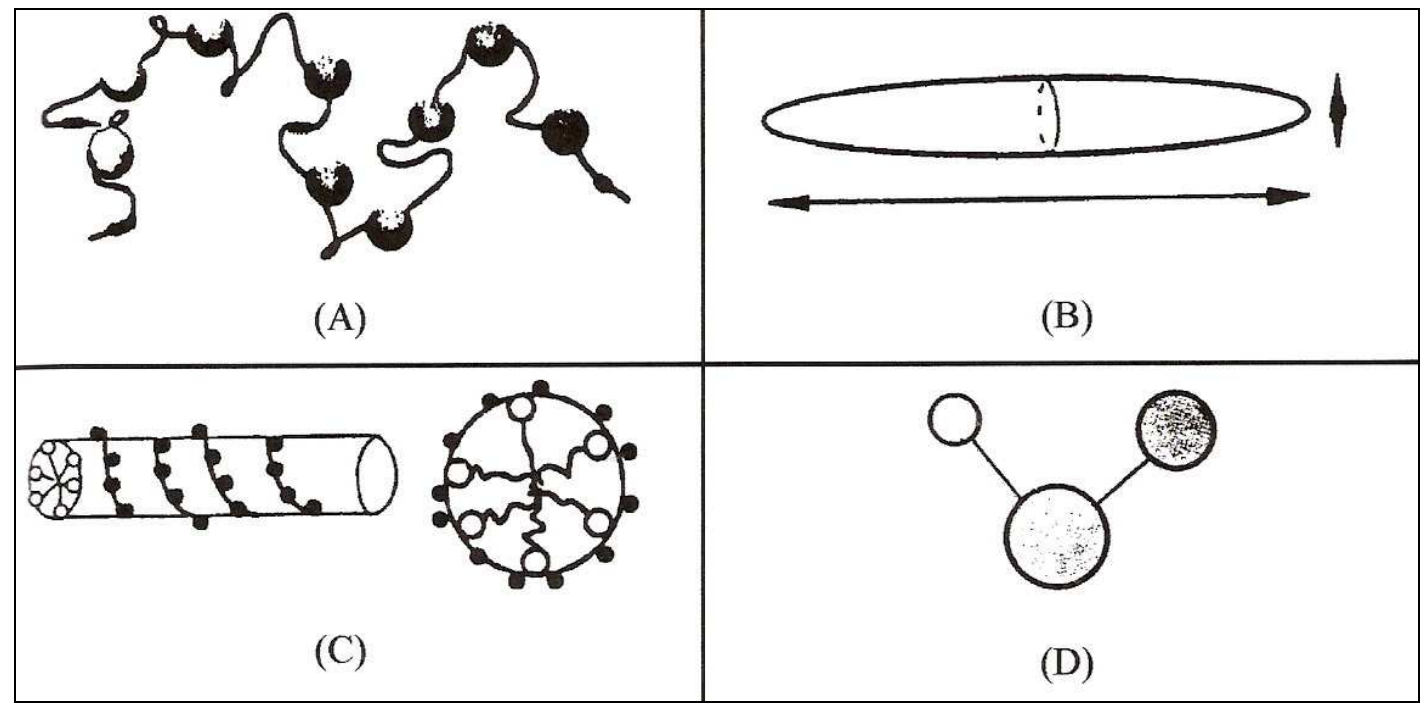

Figura 11 - Modelos para a interação proteína-surfactante.

No modelo conhecido como "colar de pérolas" (figura $11 \mathrm{~A}$ ), cachos de micela ligam-se à cadeia polipeptídica. Neste modelo, são possíveis duas estruturas. Na primeira delas (figura 12 A), a cadeia polipeptídica enrola-se em torno da micela, diminuindo a mobilidade da cabeça polar do surfactante. $\mathrm{Na}$ segunda (figura $12 \mathrm{~B}$ ), as micelas encontram-se nucleadas nos sítios hidrofóbicos da proteína e a mobilidade das cabeças polares não é afetada (Turro, 1995). No segundo modelo, as moléculas de surfactante agregam-se formando um elipsóide prolato cujo semi-eixo menor mede aproximadamente $18 \AA ̊$, que corresponde ao comprimento da cadeia do surfactante (figura $11 \mathrm{~B}$ ). Neste modelo, a cadeia polipeptídica encontra-se enrolada em torno do agregado. No terceiro modelo, as moléculas de surfactante agregam-se formando um bastão micelar cilíndrico flexível no qual a cadeia polipeptídica da 
proteína enrola-se de forma helicoidal sobre o bastão (figura $11 \mathrm{C}$ ). No quarto modelo, propõe-se que a proteína organiza o surfactante dentro de uma micela complexa (figura $11 \mathrm{D})$.

A determinação da estrutura dos complexos proteína-surfactante não é trivial, particularmente no que se refere às proteínas globulares que possuem ligações dissulfeto internas intactas. O sucesso da técnica SDS-PAGE, que depende da existência de uma carga uniforme por comprimento da cadeia polipeptídica, sugere que os complexos têm uma conformação extendida, com as moléculas de surfactantes ligadas uniformemente ao longo da cadeia (Jones, 1995).

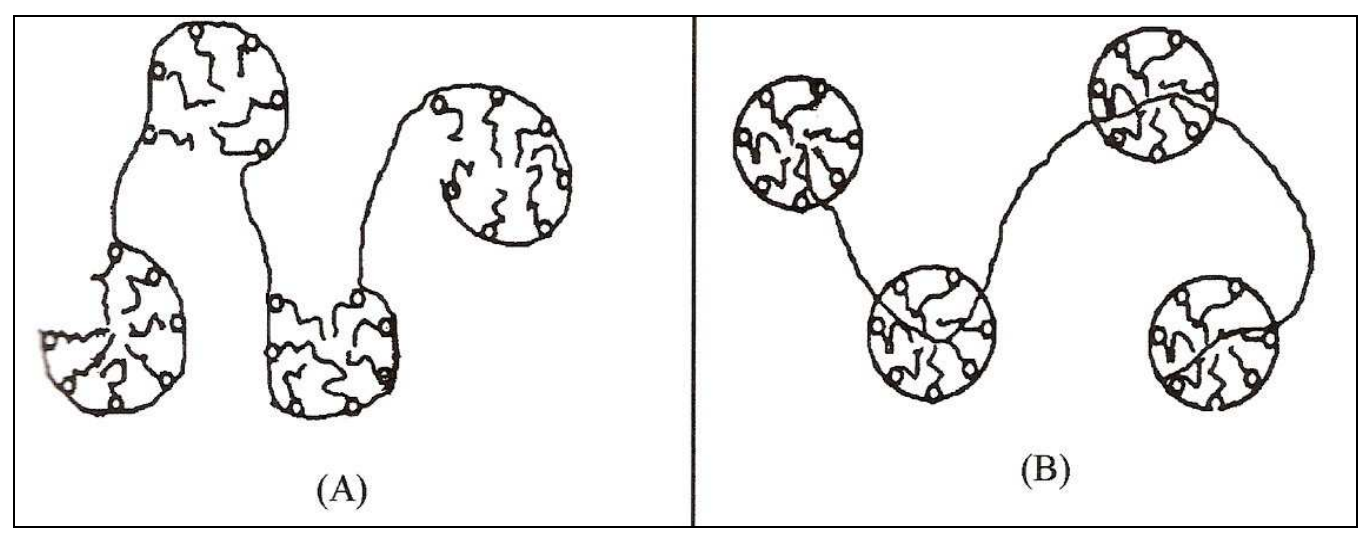

Figura 12 - Estruturas possíveis para os complexos proteína-surfactante no modelo "colar de pérolas". (A) A cadeia polipeptídica se enrola ao redor da micela; (B) As micelas encontram-se nucleadas nos sítios hidrofóbicos da proteína. 
Em trabalhos anteriores do grupo, Gelamo e colaboradores (Gelamo, 2004) verificaram por SAXS que na interação da HbGp íntegra em pH 7,0 com o surfactante SDS ocorre a dissociação da sua estrutura oligomérica, sendo que a intensidade dessa dissociação depende da concentração do surfactante. Com uma relação de SDS/proteína de 20, inicialmente a proteína íntegra se dissociaria em duas camadas hexagonais. Entretanto, uma mudança mais drástica na estrutura oligomérica somente aconteceria com uma relação de surfactante/proteína de 200. Desta forma, o raio de giro diminui para aproximadamente $30 \AA$, sugerindo a dissociação da proteína íntegra em subunidades menores.

Uma vez que o surfactante provoca alterações na estrutura oligomérica da proteína, gerando tanto a dissociação das subunidades como eventuais modificações nas estruturas secundárias e terciárias de cada cadeia polipeptídica, essas alterações poderiam se propagar em maior ou menor grau para a primeira esfera de coordenação do ferro. Desta maneira, o estudo da auto-oxidação da HbGp com o surfactante SDS seria uma abordagem interessante para se obter informações sobre a estabilidade da estrutura oligomérica da hemoglobina, o ambiente hidrofóbico do heme e seu enovelamento polipeptídico.

É descrito na literatura que o surfactante SDS poderia aumentar ou diminuir a velocidade de auto-oxidação dependendo de sua concentração. Para a hemoglobina humana, é proposto que a formação da espécie metahemoglobina através da auto-oxidação é inibida pelo SDS quando o mesmo 
tem uma concentração até 10 vezes maior que a concentração da hemoglobina. No entanto, para concentrações maiores de SDS, a formação da espécie metahemoglobina é favorecida (Reza, 2002). O SDS em baixas concentrações mudaria a conformação da proteína para um estado mais enovelado. Este estado mais compacto poderia prevenir a entrada da molécula de água na cavidade hidrofóbica do heme, que é necessária para promover o processo de oxidação através do ataque nucleofílico (Reza, 2002).

Portanto, o presente trabalho apresenta resultados e discussões relevantes para a compreensão da relação estrutura-função da hemoglobina extracelular gigante de Glossoscolex paulistus no que se refere ao processo de auto-oxidação induzida ou não pela presença de surfactante, em diferentes valores de $\mathrm{pH}$ e suas eventuais correlações com o mesmo fenômeno em outras hemoproteínas estudadas na literatura. 


\subsection{Técnicas espectroscópicas}

\subsubsection{O Espectro de absorção na região do ultravioleta-visível das porfirinas.}

A atribuição do espectro na região do ultravioleta-visível das porfirinas, apesar de muito estudado, não é algo trivial e ainda se encontra em evolução os modelos químico-quânticos que explicam suas bandas, freqüências e intensidades. Um dos tópicos pesquisados em trabalhos teóricos diz respeito à grande diferença de intensidade entre as bandas $B$ e $Q$, que são as principais bandas $\pi-\pi^{\star}$ intraligantes da porfirina.

O espectro eletrônico das porfirinas apresenta duas regiões bastante características referentes às bandas $B$ e $Q$, que são transições predominantemente intraligantes, ou seja, transições que envolvem orbitais moleculares do macrociclo porfirínico. Entre as bandas que apresentam contribuição do metal, destacam-se as bandas de transferência de carga, que apesar da menor absortividade molar em relação às bandas $\mathrm{B}$ e $\mathrm{Q}$, fornecem informações valiosas sobre o desdobramento dos orbitais $d$ e a superposição de orbitais entre metal e porfirina. A banda B também chamada banda de Soret, é a mais intensa, apresentando uma absortividade molar altíssima, superior a 100.000 L.mol ${ }^{-1} \mathrm{~cm}^{-1}$, o que explica a aplicação das porfirinas como protótipo de corantes (Antonini, 1981).

Para a banda $Q$, ressalta-se que são quatro picos na base livre e somente dois na metaloporfirina, $\alpha$ e $\beta$, o que é indicativo do aumento de 
simetria pela adição do centro metálico. Igualmente é interessante o fato da banda $\mathrm{Q}$ apresentar uma intensidade bem inferior à banda de Soret, situandose sua absortividade molar na faixa entre 10.000 e 15.000 L.mol ${ }^{-1} \mathrm{~cm}^{-1}$. As bandas $Q$ em metaloporfirinas são denominadas $\alpha$ e $\beta$, e têm sido consideradas variações vibracionais de uma mesma transição eletrônica sendo que a banda $\alpha$ é atribuída a uma transição $Q(0,0)$ ao passo que a banda $\beta$ é atribuída a uma transição $Q(0,1)$.

Segundo Antonini e colaboradores (Antonini, 1981), pode-se eliminar a possibilidade de transição $d$ - $d$ em configurações alto spin, pois como existem cinco elétrons paralelos, as transições $d$ - $d$ devem resultar em emparelhamento de spin e são, portanto, proibidas pela regra de seleção que requisita que não ocorra mudança na multiplicidade de spin. Os coeficientes de absortividade molar para transições proibidas por spin em complexos de metais da primeira série de transição são de 0,01 a 10 L.mol ${ }^{-1} \mathrm{~cm}^{-1}$, muito menores do que os valores observados em hemoproteínas em torno de $10^{3} \mathrm{~L} \cdot \mathrm{mol}^{-1} \mathrm{~cm}^{-1}$. Importante acrescentar que, mesmo para sistemas baixo-spin, tal transição não é freqüentemente observada, uma vez que na maioria dos casos se encontram superpostas por bandas de maior absortividade molar. 


\subsubsection{Dicroísmo Circular em hemoproteínas.}

Dicroísmo circular é uma poderosa ferramenta para se estudar a estrutura de biomoléculas (Zhu, 2002). De fato, dicroísmo circular constitui-se em uma técnica sensível às mudanças conformacionais das proteínas, pois permite avaliar alterações na estrutura secundária das mesmas (Nagatomo, 2002). Vale lembrar que a técnica dicróica também apresenta uma variedade magnética, que consiste no dicroísmo circular magnético, igualmente com ampla aplicação em estudos biofisícos.

Quando somente uma parte da conformação $\alpha$-hélice modifica-se para uma disposição aleatória ou para um outro tipo de conformação helicoidal, o espectro de dicroísmo circular resultante pode reter a forma original, mas a sua intensidade será reduzida. Uma pequena mudança na intensidade do espectro de dicroísmo circular deve representar uma leve influência sobre a estrutura secundária (Zhu, 2002). 


\subsubsection{Fluorescência de Proteínas}

As proteínas contêm três resíduos de aminoácidos que contribuem para a sua fluorescência na região do ultravioleta-visível: o triptofano, a tirosina e a fenilalanina (Figura 13). Esses aminoácidos são denominados fluoróforos e seus grupos aromáticos responsáveis pela emissão de luz são os cromóforos. A fluorescência das proteínas é basicamente pelos resíduos de triptofano, sendo que o indol desses resíduos de aminoácidos é o fluoróforo. O indol do triptofano e de seus derivados é muito importante, permitindo distinguir a localização de resíduos protegidos e expostos.

A grande maioria das proteínas possuem fluoróforos intrínsecos, daí o grande número de dados existentes de fluorescência de proteínas. A maior vantagem do uso da fluorescência intrínseca da proteína não é apenas de se evitar a modificação química, mas também o risco de uma perturbação estrutural decorrente dessa modificação. Porém, existe uma desvantagem, pois a maioria das proteínas contém mais que um resíduo de triptofano ou tirosina e, desde que cada resíduo tem seu ambiente, as propriedades espectrais de cada um serão diferentes. $O$ espectro de emissão seria uma sobreposição da emissão de cada resíduo. Portanto, torna-se uma tarefa difícil separar a contribuição espectral de cada aminoácido luminescente (Lakowicz, 1983). 


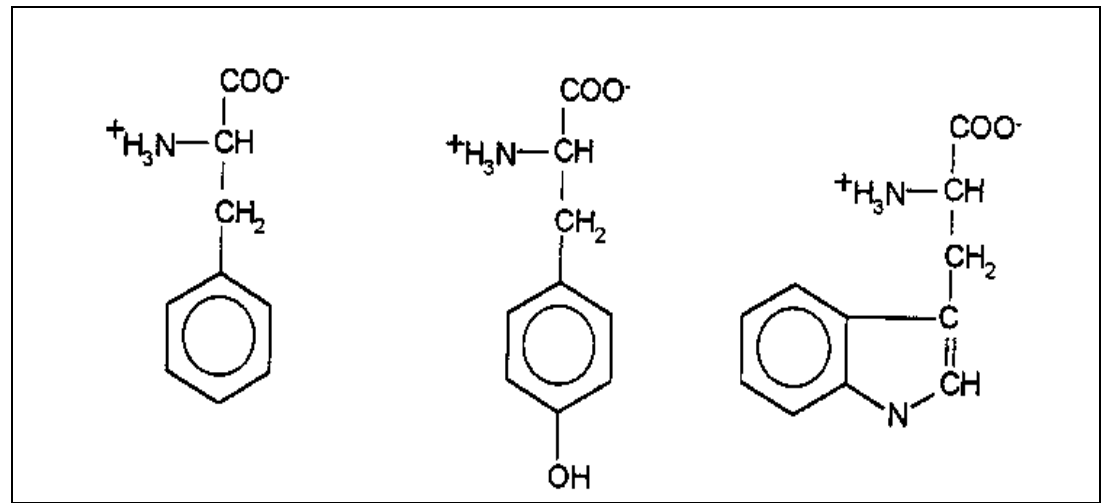

$\begin{array}{lll}\text { Fenilalanina } & \text { Tirosina } & \text { Triptofano }\end{array}$

Figura 13 - Aminoácidos fluorescentes (Szabo, 1989). 


\section{OBJETIVOS}

O presente trabalho tem por objetivo:

1) Estudo da interação do monômero $d$ da hemoglobina extracelular de G. paulistus na sua forma oxi $\left(\mathrm{Fe}^{+2}\right)$ nos $\mathrm{pH} 7,0$ e 9,0 com os detergentes SDS, CTAC e BRIJ - 35 através da absorção UV-Vís.

2) Estudo da interação do monômero $d$ da hemoglobina extracelular de G. paulistus na sua forma oxi $\left(\mathrm{Fe}^{+2}\right)$ nos $\mathrm{pH} 7,0$ e 9,0 com os detergentes SDS, CTAC e BRIJ - 35 através da fluorescência.

3) Investigar o comportamento da estrutura secundária do monômero $d$ da hemoglobina extracelular de G. paulistus na sua forma oxi $\left(\mathrm{Fe}^{+2}\right)$ nos $\mathrm{pH}$ 7,0 e 9,0 com os detergentes SDS, CTAC e BRIJ - 35 através da técnica de dicroísmo circular. 


\section{MATERIAIS E MÉTODOS}

\subsection{Materiais}

\subsubsection{Animal Utilizado}

A $\mathrm{Hb}$ utilizada neste trabalho é extraída do anelídeo G. paulistus. Os espécimes são coletados na região de Rio Claro e mantidos à temperatura ambiente até o momento da coleta do sangue.

\subsubsection{Equipamentos}

- pHmetro Digital PG 1800 - Gekaba;

- Centrífuga refrigerada Hitachi modelo CR20B2;

- Ultracentrífuga refrigerada Sorval 250;

- Coluna de filtração em gel;

- Coletor de frações ISCO Retriever III modelo 328;

- Espectrofotômetro Shimadzu modelo UV-1601PC;

- Espectrofluorímetro Hitachi modelo F-4500;

- Espectropolarímetro Jasco modelo J-720;

\subsubsection{Reagentes e Outros}

- Sigma Chemical Co. - Dodecil sulfato de sódio (SDS); Polioxietileno lauril éter (BRIJ-35); Sephadex G-200; 
- Aldrich Chemical Co. - Cloreto de cetiltrimetilamônio (CTAC); TRIS-HCI (Cloridrato de hidroximetilaminometano);

- Merck Chemicals - EDTA, Hidróxido de Sódio, Ferricianeto de potássio, Ácido Clorídrico;

- A membrana utilizada nas diálises das amostras tinha diâmetro de 16 nm, 3787 D 22, da A. H. Thomas Co.;

\subsection{Métodos}

\subsubsection{Obtenção e purificação - Oxi-hemoglobina íntegra e Monômero.}

Os animais foram lavados em água corrente, anestesiados com éter e realizado um corte no dorso de cada espécime. A hemolinfa foi extraída com pipetas de Pauster em presença de anti-coagulante (citrato de sódio 0,1 mmol $\mathrm{L}^{-1}$ ) e armazenada em tubos de Eppendorf mantidos em banho gelado durante a coleta. A primeira etapa da purificação foi realizada através de centrifugação da hemolinfa a 500 rpm por 10 minutos a $4^{\circ} \mathrm{C}$ para precipitação de impurezas tais como restos de células e outros detritos sólidos. O sobrenadante foi submetido para a diálise contra tampão TRIS-HCl $100 \mathrm{mmol} \mathrm{L}^{-1}, \mathrm{pH} 7,0 \mathrm{com} \mathrm{0,1}$ mmol $\mathrm{L}^{-1}$ EDTA por uma noite a $4^{\circ} \mathrm{C}$ empregando-se uma membran a de diálise que retém proteínas globulares de massa molecular superior a 16 kDa. Após a diálise foi realizada a ultracentrifugação da proteína a ${ }^{4} \mathrm{C}$ por 6 horas a 35000

rpm e o precipitado foi ressuspendido em tampão TRIS-HCl $100 \mathrm{mmol} \mathrm{L}{ }^{-1}, \mathrm{pH}$ 7,0 com 0,1 mmol L-1 EDTA e a purificação final foi feita por cromatografia de 
exclusão em coluna de gel Sephadex G-200 de $100 \mathrm{~cm}$ de comprimento por 0,9 $\mathrm{cm}$ de diâmetro equilibrada com tampão TRIS-HCl $100 \mathrm{mmol} \mathrm{L}^{-1}, \mathrm{pH}$ 7,0 com $0,1 \mathrm{mmol} \mathrm{L}^{-1}$ EDTA. Como o eluato coletado no volume de exclusão contém a oxiHb íntegra este foi estocada a $4^{\circ} \mathrm{C}$ para uso post erior (Imasato, 1995).

A fração oxi-monômero foi separada aplicando-se a oxiHb íntegra em pH 9,0 em uma coluna de gel Sephadex G-200 de $100 \times 0,9 \mathrm{~cm}$ equilibrada com tampão TRIS-HCl $20 \mathrm{mmol} \mathrm{L}^{-1}$, pH 9,0 com 0,1 $\mathrm{mmol} \mathrm{L}^{-1}$ EDTA.

\subsubsection{Medidas de Absorção Ótica}

Os espectros de absorção ótica foram medidos entre $250-700 \mathrm{~nm}$, em uma cubeta de $1 \mathrm{~mL}$, com caminho ótico de $1 \mathrm{~cm}$, utilizando um espectrofotômetro Shimadzu modelo UV-1601 PC à temperatura ambiente. Os espectros obtidos foram armazenados a fim de serem posteriormente analisados empregando-se o programa CCA ("convex constraint analysis") de Fasman e colaboradores (Perczel, 1992). O programa CCA permite calcular os espectros das espécies químicas que coexistem em solução (espectros que foram denominados de espectro base) a partir de um conjunto dos espectros experimentais (funções iniciais). Um espectro de absorção numa dada condição experimental pode ser representado pela função $A(\lambda)$ :

$$
A(\lambda)=\sum_{i=1}^{P} a_{i} A_{i}(\lambda)
$$


nesta equação $a_{i}$ é o coeficiente que determina a proporção do constituinte $i$; $A_{i}(\lambda)$ são os espectros das soluções das espécies químicas $i$, constituindose nos espectros bases; $P$ é o número total de espécies químicas em solução. As restrições impostas pelo programa são:
1) $\sum_{i=1}^{P} a_{i}=1$;
2) $a_{i} \geq 0$;
3)
$A_{i}{ }^{\prime} s \quad$ são
linearmente

independentes.

Os espectros - $A_{i}(\lambda)$ - e as proporções - $a_{i}$ - são obtidos através de avaliação estatística convex constraint.

\subsubsection{Medidas de Fluorescência}

Para as medidas de emissão de fluorescência da fração monomérica da hemoglobina de G. paulistus na forma meta e oxi em pH 7,0 e 9,0 em função da concentração de SDS, CTAC e BRIJ-35 foi utilizado um espectrofluorímetro HITACHI F-4500, usando uma cubeta de quartzo com as quatro faces polidas e caminho ótico de $1 \mathrm{~cm}$. O comprimento de onda de excitação foi de $295 \mathrm{~nm}$ e o espectro de emissão acompanhado entre 305 a $450 \mathrm{~nm}$. As amostras foram preparadas com absorbância em $295 \mathrm{~nm}\left(\mathrm{~A}_{295}\right) \leq 0,1$, com o objetivo de se evitar os efeitos de absorbância interna. Todos os resultados foram normalizados para um valor de $\mathrm{A}_{295}=0,1$. 


\subsubsection{Medidas de Dicroísmo Circular}

As medidas de dicroísmo circular foram realizadas em um espectropolarímetro JASCO J-720 e as amostras foram propagadas da mesma forma que nos experimentos de fluorescência estática. Estas medidas foram realizadas numa cubeta circular de caminho ótico de $1 \mathrm{~cm}$. 


\section{RESULTADOS E DISCUSSÕES}

4.1 Estudo da interação da fração oxi-monômero em pH 7,0 e 9,0 da hemoglobina de G. paulistus (HbGp) com SDS, CTAC e BRIJ-35 através da fluorescência e absorção UV-Vís.

A espectroscopia de fluorescência foi usada para monitorar mudanças na estrutura terciária induzidas pelas interações com os surfactantes. Estas interações podem, em princípio, produzir mudanças na posição ou orientação dos resíduos de triptofano, alterar sua exposição ao solvente, gerando mudanças no rendimento quântico e no máximo de emissão.

As titulações do oxi-monômero da hemoglobina de G. paulistus com SDS, CTAC e BRIJ-35 foram efetuadas em pH 7,0 e 9,0 empregando-se tampão tris- $\mathrm{HCl} 20 \mathrm{mmol}^{-1}$. O procedimento consistiu na adição de alíquotas de soluções estoques do surfactante diretamente na cubeta, e os espectros de emissão de fluorescência e de absorção ótica foram registrados após cada adição de surfactante.

Espectroscopia de absorção UV-Vís foi utilizada para se obter uma análise mais detalhada das interações que ocorrem na primeira esfera de coordenação em função das interações proteína-surfactante. 


\subsubsection{Titulação do oxi-monômero da HbGp com SDS em pH 7,0}

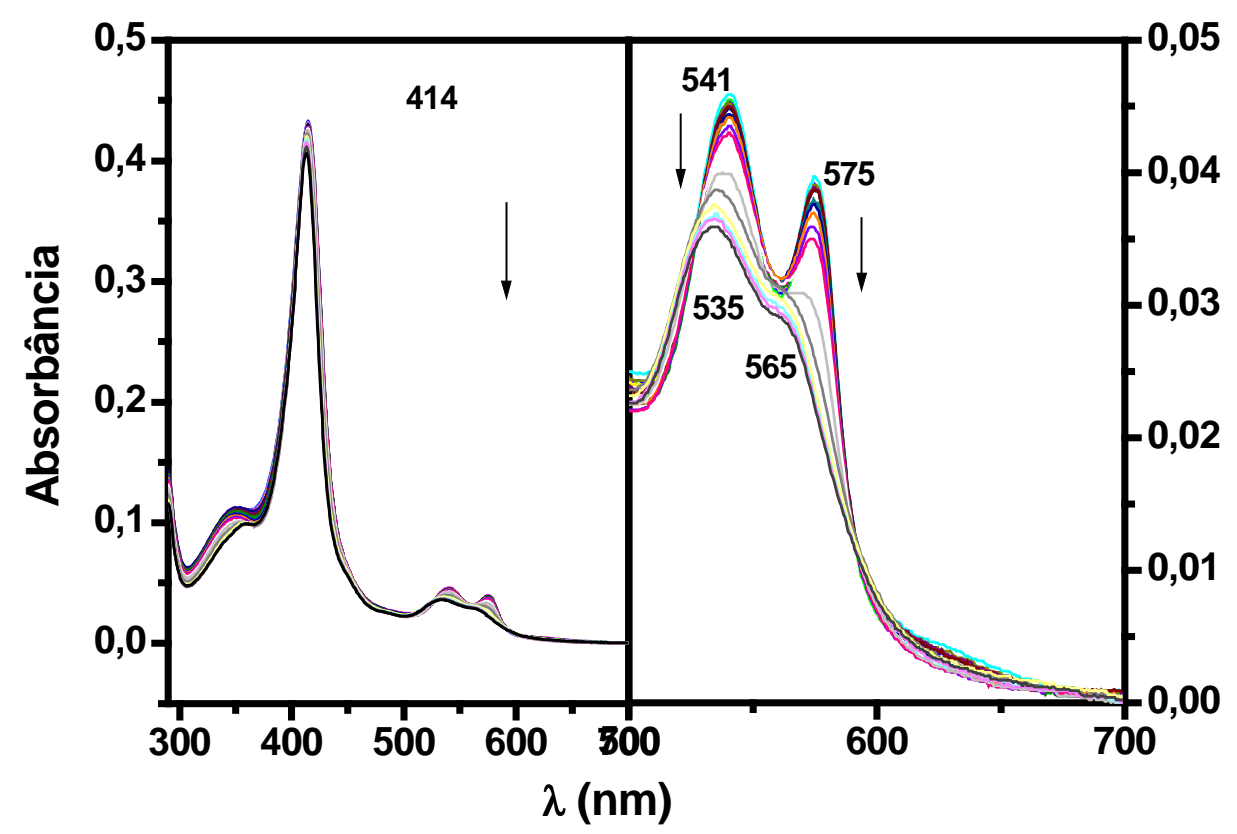

Figura 14: Espectros de absorção UV-Vís do oxi-monômero de G. paulistus em tampão Tris- $\mathrm{HCl} 20 \mathrm{mmol} \mathrm{L}^{-1}, \mathrm{pH}$ 7,0 em função da concentração de SDS na faixa de $0,005-1,0 \mu \mathrm{M}$.

Podemos observar através dos espectros de absorção UV-Vís apresentado (figura 14), que ocorreu a oxidação do monômero durante a titulação com SDS. Porém para baixas concentrações de SDS, a absorbância em $414 \mathrm{~nm}$ variou apenas ligeiramente. Portanto na faixa de concentração de SDS onde ocorreram as interações específicas do detergente com o monômero, este ainda se encontrava essencialmente na forma oxi. Em concentrações mais elevadas de SDS, as moléculas de detergente provocam alterações mais profundas, caracterizando-se inclusive a desnaturação, facilitando a oxidação do oxi-monômero que pode ser observada através das 
bandas $\alpha$ e $\beta$ em $541 \mathrm{~nm}$ e $575 \mathrm{~nm}$ respectivamente, ocorrendo uma diminuição na posição dos seus máximos de absorção $535 \mathrm{~nm}$ para a banda $\alpha$ e $565 \mathrm{~nm}$ cujas alterações, caracterizam a formação da espécie hemicromo (complexo bis-histidina de baixo spin) (AGUSTINHO et al.1996)(MOREIRA et al.2006).

A figura 15 ilustra a variação da fluorescência total (A, área sob a curva de emissão) normalizada pela fluorescência total do monômero na ausência de surfactante, $A_{0}$. As áreas foram previamente corrigidas em relação à variação da absorbância no comprimento de onda de excitação e em relação ao efeito de diluição devido às adições das alíquotas da solução estoque de SDS.

$\mathrm{Na}$ titulação do oxi-monômero com SDS em pH 7,0 foram identificadas duas fases. Inicialmente foi observado um aumento no máximo da fluorescência, sugerindo que as alterações de fluorescência observadas são decorrentes da interação do SDS com a cadeia peptídica. O aumento do rendimento quântico de fluorescência indica que a supressão da emissão dos triptofanos pelos hemes é reduzida pela adição do surfactante. Isto pode ser devido ao aumento nas distâncias relativas e/ou uma mudança na orientação entre os resíduos de triptofano e o heme que é o principal supressor da fluorescência em hemoglobinas.

Para concentrações de SDS acima de $0,1 \mu \mathrm{M}$ ocorreu uma diminuição do rendimento quântico para 1,6 vezes para $0,2 \mu \mathrm{M}$ de SDS, devido a supressão de fluorescência dos resíduos de TRP, isso indica que aumentou apenas ligeiramente até 1,7 vezes para 0,8 $\mu \mathrm{M}$ de SDS (figura 15). De forma, geral pode-se propor interações iniciais das moléculas de 
SDS em sítios catiônicos na cadeia polipeptídica do monômero, especialmente os resíduos lisil, histidil e arginil (TURRO e LEI, 1995), que se completa até a adição de 0,1 $\mu \mathrm{M}$ de SDS. Após esta concentração de SDS ocorrem transformações devido às interações com as moléculas de detergentes que poderão provocar até a desnaturação da proteína.

Para se extrair os parâmetros de interação do detergente com o oximonômero, o conjunto de espectros de fluorescência obtidos em função da concentração de SDS (figura 16(A)) foi analisado empregando-se o método CCA (PERCZEL et al.1992). A análise foi feita considerando-se a variação espectral devido às transformações evolvendo três espécies químicas, e os espectros individuais destes componentes estão apresentados na figura 16(B). A decomposição do conjunto de espectros de emissão em duas componentes mostrou claramente que o modelo era inadequado sendo necessário adicionar mais uma componente. A presença da espécie intermediária foi proposta a partir da análise da fluorescência em função da concentração de SDS (figura 15). A primeira espécie centrada em $326 \mathrm{~nm}$ foi associada ao oxi-monômero puro. A segunda espécie centrada em $323 \mathrm{~nm}$ foi associada ao complexo oximonômero -SDS predominante na faixa de SDS de 0,03 $\mu \mathrm{M}-0,23 \mu \mathrm{M}$. A terceira espécie, centrada em $328 \mathrm{~nm}$ foi associada ao monômero desnaturado e é a única espécie até $1 \mu \mathrm{M}$ de SDS.

$\mathrm{Na}$ figura $16(\mathrm{C})$ estão apresentadas as contribuições, frações, de cada espécie no espectro experimental em função da concentração de SDS. 


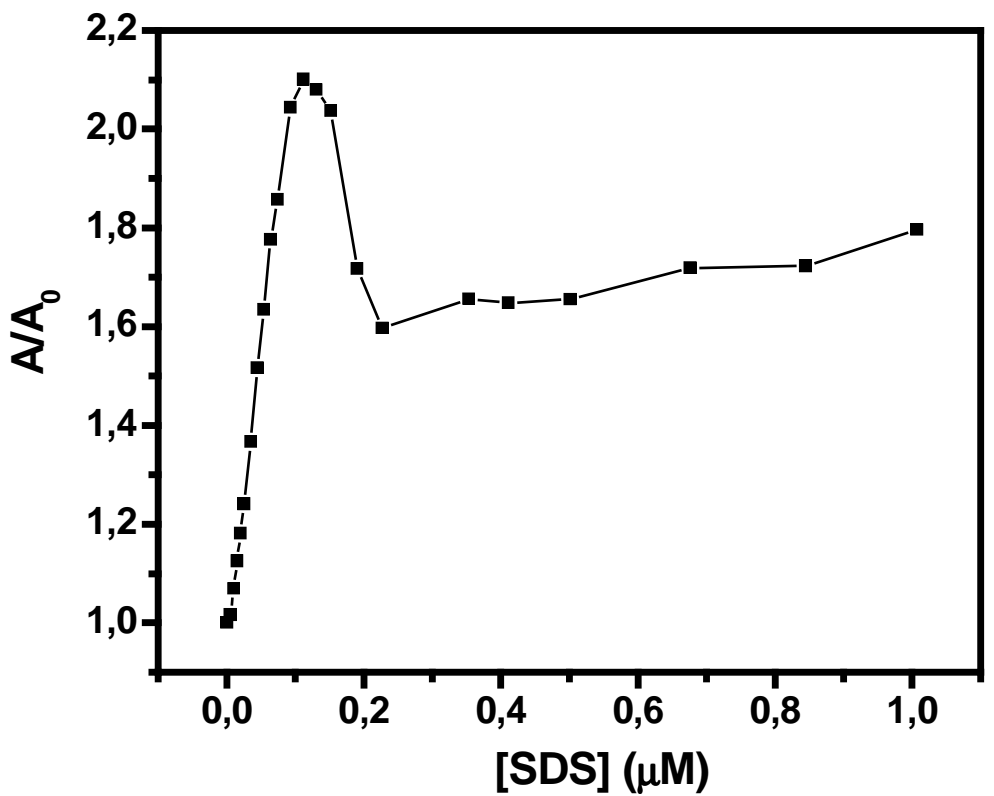

Figura 15: Áreas normalizadas dos espectros de emissão do oxi-monômero de G. paulistus em tampão Tris- $\mathrm{HCl} 20 \mathrm{mmol} \mathrm{L}^{-1}(\mathrm{pH} 7,0), \lambda_{\mathrm{exc}}=295 \mathrm{~nm}, \lambda_{\mathrm{em}}=305$ -450 nm, em função da concentração de SDS. 

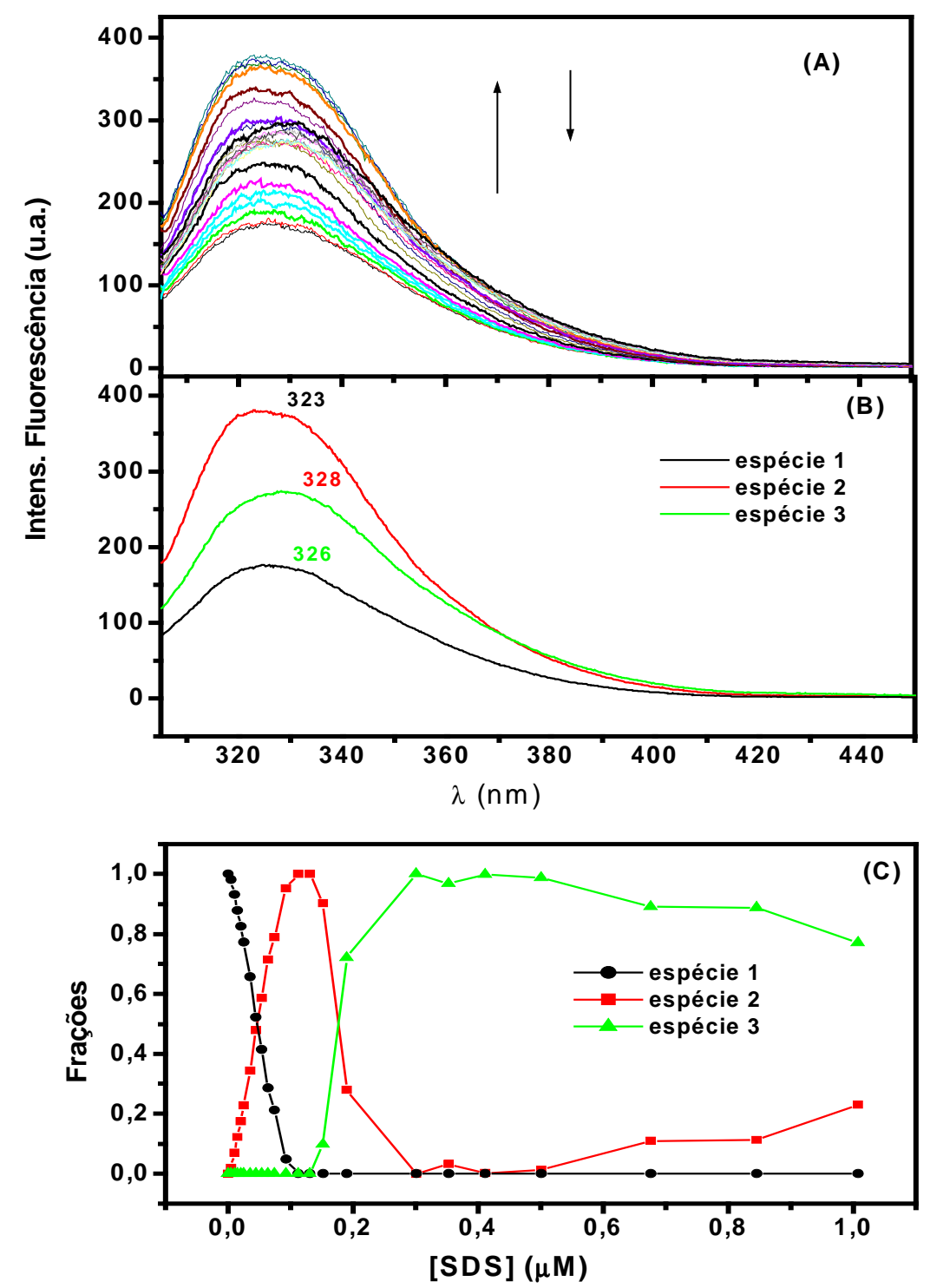

Figura 16: (A) Espectros de emissão do oxi-monômero de G. paulistus em tampão Tris- $\mathrm{HCl} 20 \mathrm{mmol} \mathrm{L}^{-1}(\mathrm{pH} 7,0), \quad \lambda_{\mathrm{exc}}=295 \mathrm{~nm}$ em função da concentração de SDS, (B) espécies puras: oxi-monômero puro (-•-) - espécie 1 , complexo monômero-SDS (- -) - espécie 2 e monômero desnaturado (- $\left.\Delta_{-}^{-}\right)$espécie 3, correspondentes aos componentes dos espectros experimentais presentes em diferentes proporções; (C) conteúdo relativo de cada espécie em função da concentração de SDS. 


\subsubsection{Titulação do oxi-monômero da HbGp com SDS em pH 9,0}

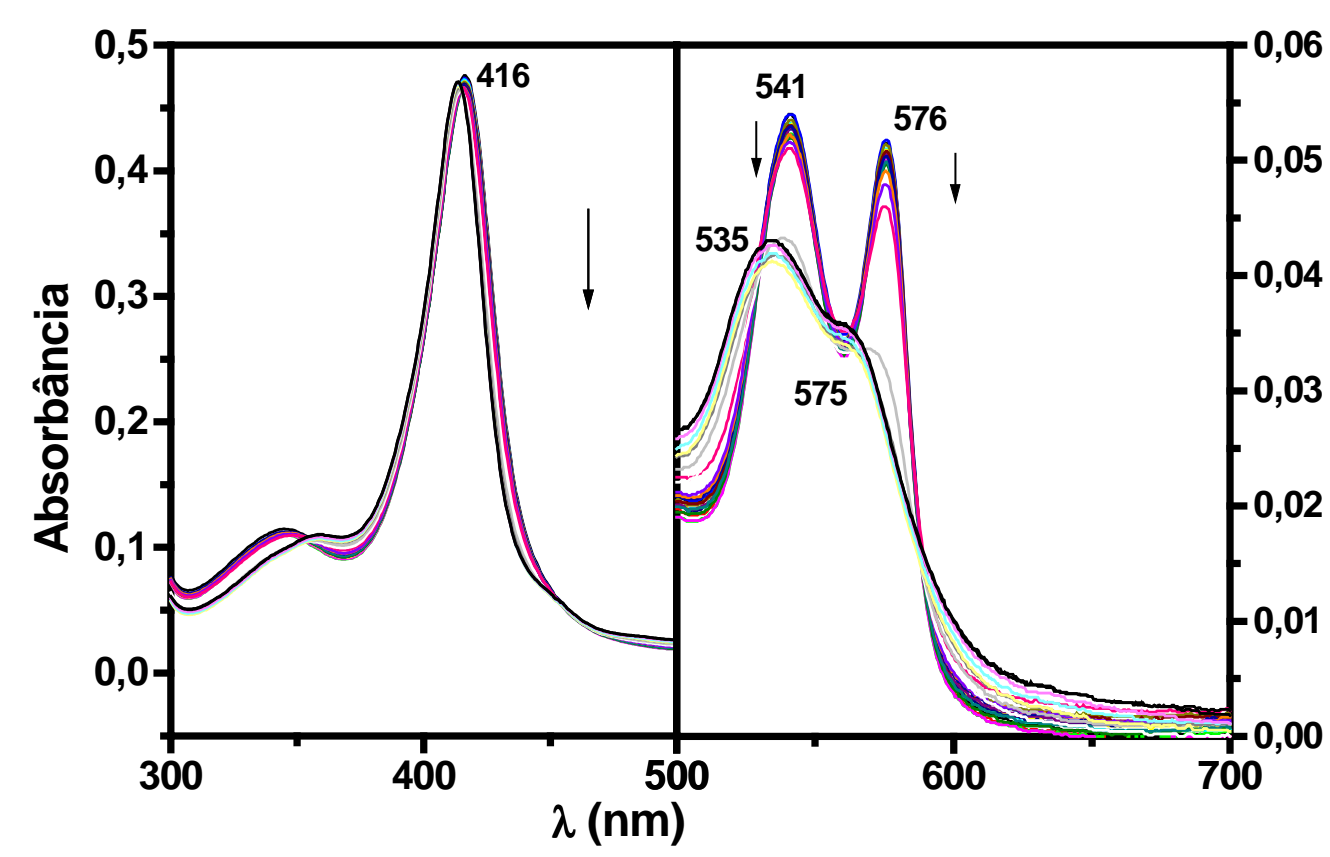

Figura 17: Espectros de absorção UV-Vís do oxi-monômero de G. paulistus em tampão Tris- $\mathrm{HCl} 20 \mathrm{mmol} \mathrm{L}^{-1}, \mathrm{pH}$ 9,0, em função da concentração de SDS na faixa de $0,005-1,2 \mu \mathrm{M}$.

Podemos observar através dos espectros de absorção UV-Vís apresentados (figura 17), que ocorreu a oxidação do monômero durante a titulação com SDS. A banda de Soret centrada em 416 nm, com a adição de SDS diminui ligeiramente seu máximo de absorção em baixas concentrações de SDS onde ocorrem as interações específicas do detergente com o monômero. Em concentrações mais elevadas de SDS, as moléculas de detergente provocam alterações mais profundas, caracterizando-se inclusive a desnaturação, facilitando a oxidação do oxi-monômero observado através da 
mudanças nas bandas $\alpha$ e $\beta$ em 541 e 576 respectivamente, ocorrendo uma diminuição nos seus máximos de absorção 535 para a banda $\alpha$ e 565 para a banda $\beta$, caracterizando a oxidação do monômero, caracterizando a formação da espécie hemicromo (complexo bis-histidina de baixo spin) (AGUSTINHO et al.1996).

O fato pelo qual não se observa uma variação muito acentuada nas bandas de Soret e nas bandas $Q(\alpha$ e $\beta)$, nos espectros de absorção UV-Vís tanto em pH 7,0 como em pH 9,0, para baixas concentrações de SDS se deve que ao fato de que as interações deste tipo de detergente nestas condições com a cadeia polipeptídica não provoca uma distorção muito acentuada (SANTIAGO et al.2007), e com isso o grupo heme permanece hexacoordenado, constituindo, por conseguinte, espectros característicos de hemicromo (RIBELATTO et al.2006)(BARON et al.2000)(ANTONINI et al.1981)(VITAGLIANO et al.2004)(RACHMILEWITZ et al.1971)(TSURUGA et al.1998). Visto que como mostrado nos espectros, somente uma variação das bandas $Q(\alpha$ e $\beta)$, que nos afirma que só ocorre a oxidação do oxi-monomero.

A titulação do oxi-monômero pH 9,0 com SDS mostrou um aumento da fluorescência que ocorreu em duas etapas (figura 118). Na primeira etapa ocorreu um aumento no rendimento quântico de 1,4 vezes para $0,174 \mu \mathrm{M}$ de SDS. Na segunda etapa o aumento foi de 2,1 vezes para 1,2 $\mu \mathrm{M}$ de SDS. Desta forma, os resultados sugerem que exista também apenas uma espécie intermediária correspondendo à proteína contendo moléculas de detergente ligadas em sítios específicos. Quando comparados os espectros de emissão de 
fluorescência em pH 7,0 e 9,0, observa-se que há um aumento de fluorescência maior em pH 9,0, devido ao meio estar mais alcalino.

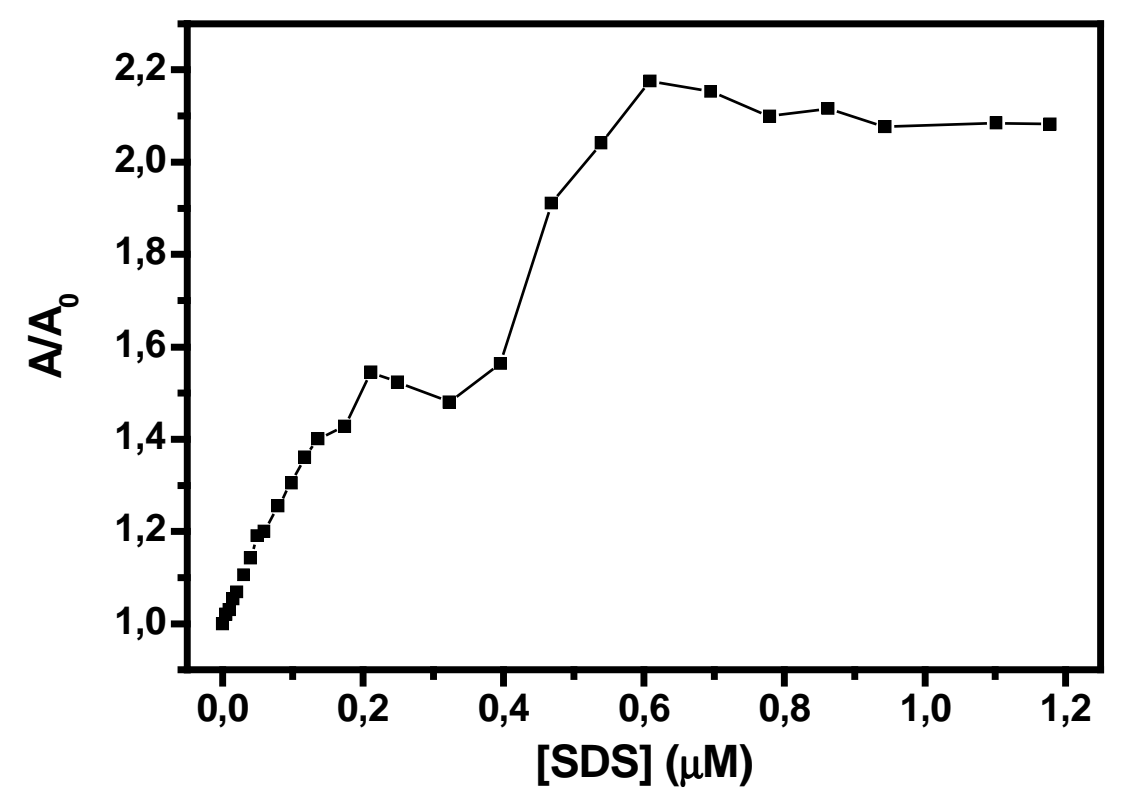

Figura 18: Áreas normalizadas dos espectros de emissão do oxi-monômero de G. paulistus em tampão Tris- $\mathrm{HCl} 20 \mathrm{mmol} \mathrm{L}^{-1}(\mathrm{pH} 9,0), \lambda_{\mathrm{exc}}=295 \mathrm{~nm}, \lambda_{\mathrm{em}}=305$ -450 nm, em função da concentração de SDS.

Do mesmo modo como em $\mathrm{pH} 7,0$, o método CCA foi aplicado para todo o conjunto de espectros, e a melhor decomposição dos espectros foi obtida com três componentes como sugerido pela análise da fluorescência total em função da concentração de SDS (figura 118). Na figura 119(A) estão apresentados o conjunto de espectros de emissão em função da concentração de SDS e os espectros dos componentes puros estão na (figura 19(B)). A primeira espécie centrada em $326 \mathrm{~nm}$ foi associada ao oxi-monômero puro. A segunda espécie 
centrada em $326 \mathrm{~nm}$ foi associada ao complexo oxi-monômero -SDS predominante na faixa de SDS de 0,08 $\mu \mathrm{M}-0,5 \mu \mathrm{M}$. A terceira espécie, centrada em $329 \mathrm{~nm}$ foi associada ao monômero desnaturado e é a única espécie até 1,2 $\mu \mathrm{M}$ de SDS.

Na figura 19 (C) estão apresentadas as contribuições de cada espécie para reproduzir os espectros experimentais em função da concentração de SDS. Apesar de se observar uma variação complexa envolvendo a transição da segunda espécie para a terceira espécie, não foi possível introduzir-se com sucesso uma componente adicional para se ajustar através do CCA os espectros experimentais.

Observa-se nos espectros de fluorescência um pequeno deslocamento do máximo de emissão para o vermelho, indicando uma maior polaridade do ambiente ao redor dos resíduos de triptofanos consistente com aumento da acessibilidade das moléculas de água do solvente para estes sítios. 

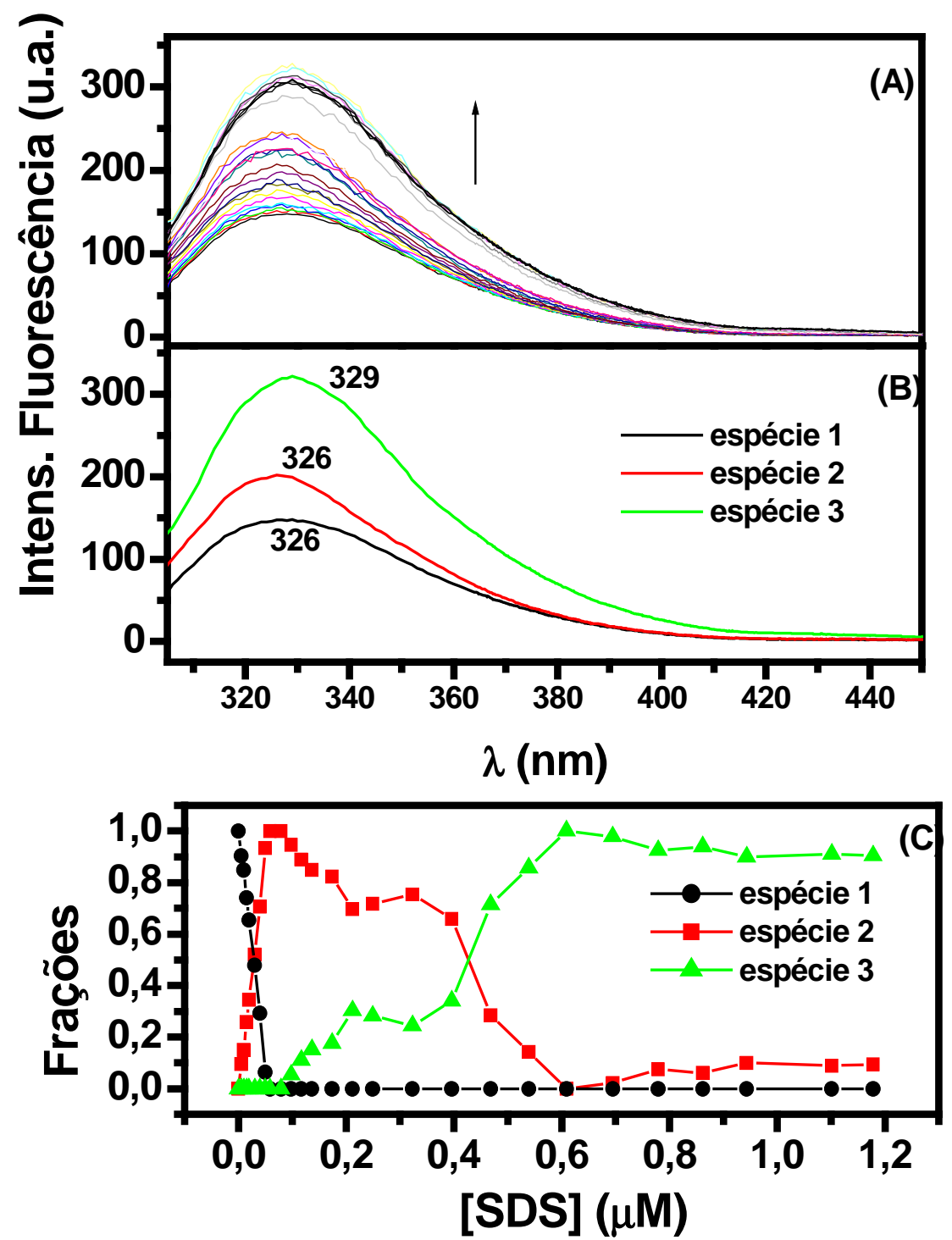

Figura 19: (A) Espectros de emissão do oxi-monômero de G. paulistus em tampão Tris-HCl $20 \mathrm{mmol} \mathrm{L}^{-1}(\mathrm{pH} 9,0), \lambda_{\mathrm{exc}}=295 \mathrm{~nm}$ em função da concentração de SDS, (B) espécies puras: oxi-monômero puro (-•-) - espécie 1, complexo monômero-SDS (-口-) - espécie 2 e monômero desnaturado (- $\left.\Delta_{-}^{-}\right)$espécie 3, correspondentes aos componentes dos espectros experimentais presentes em diferentes proporções; (C) conteúdo relativo de cada espécie em função da concentração de SDS. 


\subsubsection{Titulação do oxi-monômero da HbGp com CTAC em pH 7,0}
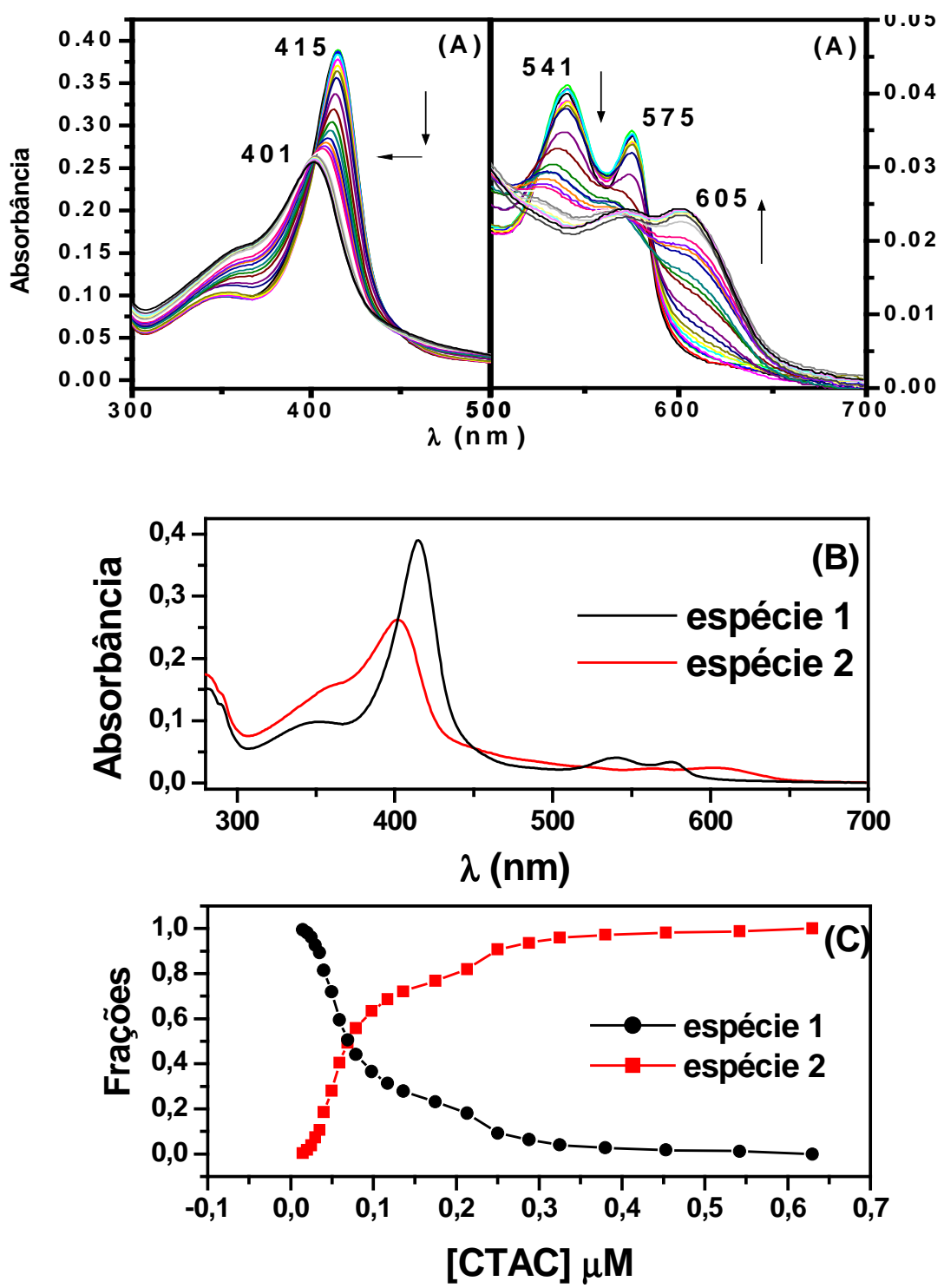

Figura 20: (A) Espectros de absorção UV-Vís do oxi-monômero de G. paulistus em tampão Tris-HCl $20 \mathrm{mmol} \mathrm{L}^{-1}(\mathrm{pH} 7,0)$, função da concentração de CTAC na faixa de 0,005 - 1,1 $\mu \mathrm{M}$, (B) espécies puras: oxi-monômero puro (-•-) - espécie 1, espécie pentacoordenada (- -) - espécie 2, correspondentes aos componentes dos espectros experimentais presentes em diferentes proporções; (C) conteúdo relativo de cada espécie em função da concentração de CTAC. 
Na figura 20(A) estão apresentados os espectros de absorção UV-Vís do oxi-monômero $d$ de G. paulistus em tampão Tris-HCl 20 mmol L ${ }^{-1}(\mathrm{pH} 7,0)$, em função da concentração de CTAC, correspondente às transições eletrônicas $\pi$ $\rightarrow \pi^{\star}$ do heme, onde a banda de Soret está centrada em $415 \mathrm{~nm}$, e as bandas $\alpha$ e $\beta$ possuem máximos, respectivamente, em $541 \mathrm{~nm}$ e $575 \mathrm{~nm}$, em pH 7,0. Este espectro é característico de oxi-hemoglobinas. Constatou-se, com a adição do surfactante CTAC, que ocorre uma diminuição da banda de Soret com deslocamento do máximo para o azul, $401 \mathrm{~nm}$ (figura 20(A)) bem como das bandas $\alpha(541 \mathrm{~nm})$ e $\beta$ (575 nm). Além disso, surge uma banda em $605 \mathrm{~nm}$ referente ao aparecimento de uma espécie pentacoordenada (MOREIRA et al.2006). Esta espécie se forma pelo fato do CTAC ser um surfactante catiônico que se liga a sítios específicos carregados negativamente, como os resíduos de aminoácidos aniônicos, por exemplo glutamil e aspartil (TURRO e LEI, 1995), provocando uma grande distorção na cadeia polipeptídica, ocorrendo assim uma distorção no grupo heme e com isso a ligação do nitrogênio do imidazol da histidina proximal F8, ou seja, oitavo resíduo da hélice $F$, se rompe formando a espécie pentacoordenada. (MOREIRA, 2006)(GILLES-GONZALEZ et al.1994)(PIETRI et al.2005).

Empregando-se o algoritmo CCA (PERCZEL et al. 992) através do emprego de duas bases obtendo-se os espectros representados na figura 20(B). Estes espectros foram atribuídos às duas espécies químicas em solução: oxi-monômero puro, espécie 1 e espécie pentacoordenada, espécie 2). 
Na figura 20(C) são apresentadas as frações de cada espécie em função da adição de CTAC.

Nas figuras 21 e 22 estão apresentados os gráficos de absorbância em função da concentração de CTAC (máximos analisados: 416 nm, 541 nm, 575 $\mathrm{nm}$ e $605 \mathrm{~nm})$.

A absorbância em 416 nm (banda de Soret) diminui com o aumento da concentração de surfactantes, ou seja, até a concentração $0,4 \mu \mathrm{M}$ observa-se diminuição acentuada da banda.

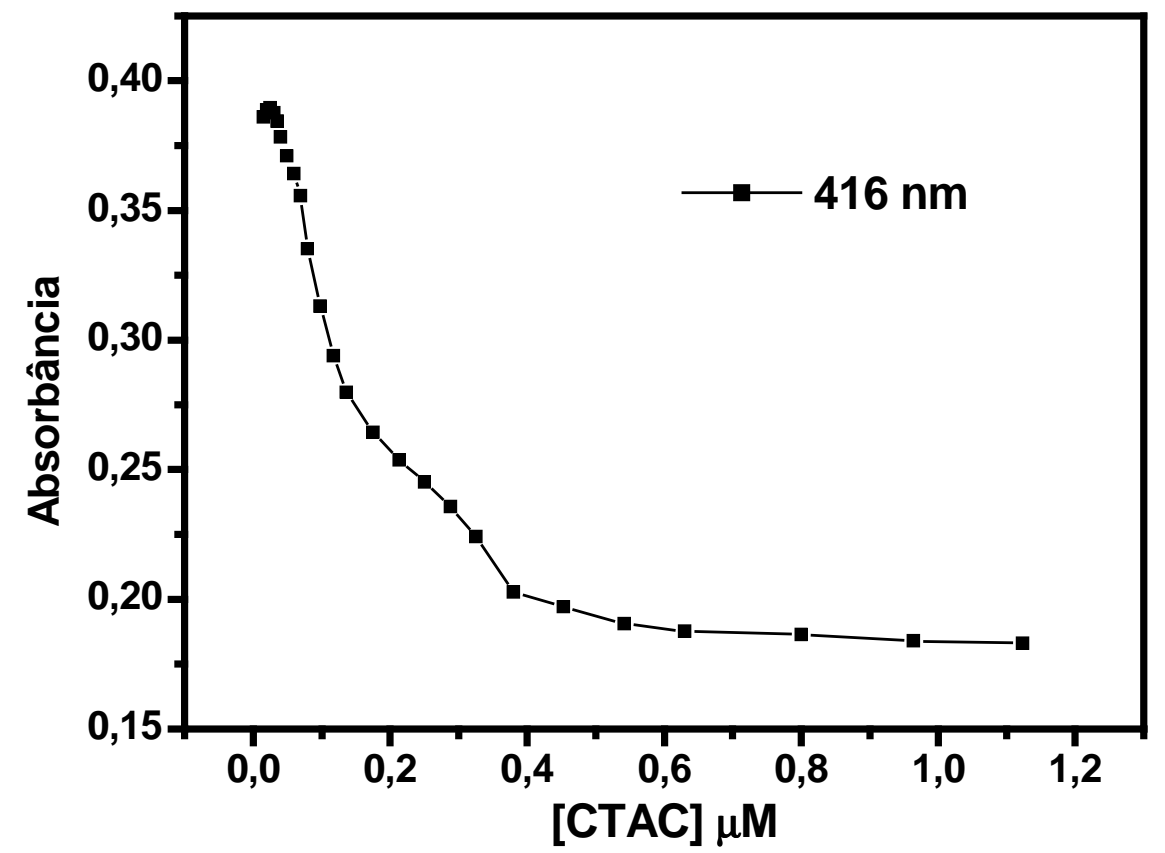

Figura 21: Gráfico de absorbância do oxi-monômero de G. paulistus em tampão Tris-HCl $20 \mathrm{mmol} \mathrm{L}^{-1}$ (pH 7,0), em função da concentração de CTAC, na região da banda de Soret. 


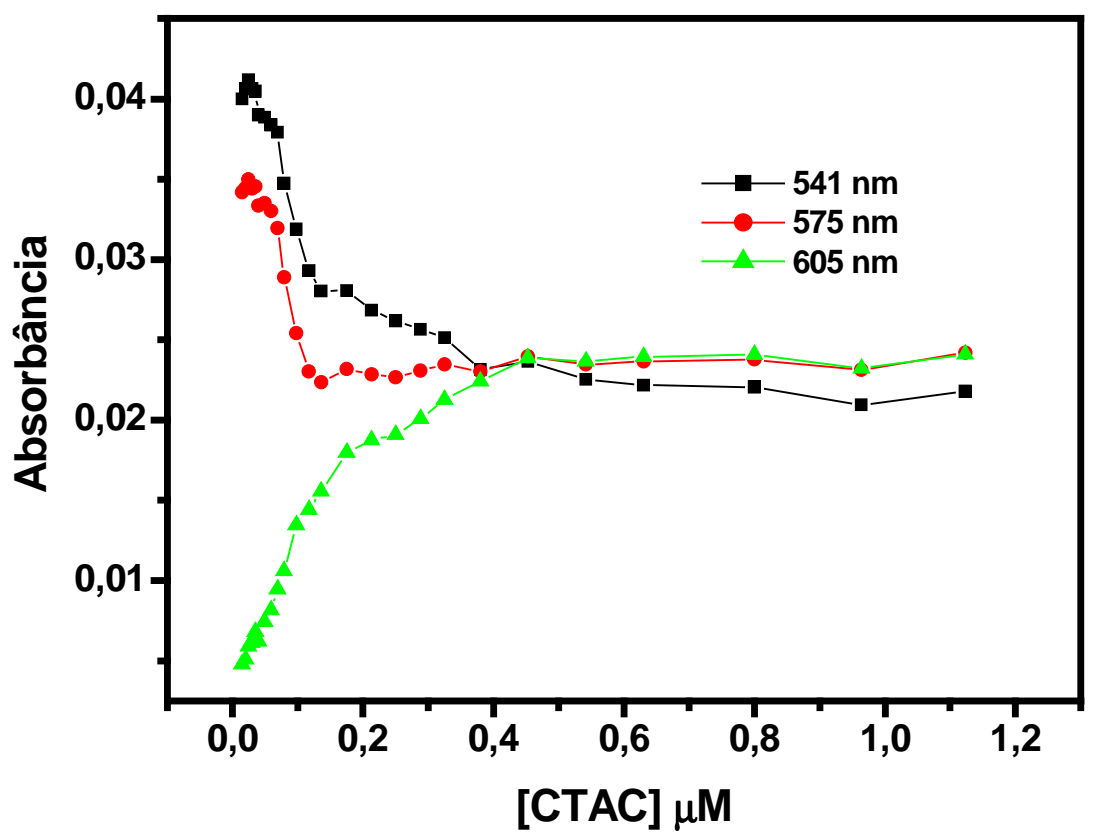

Figura 22: Gráfico de absorbância do oxi-monômero de G. paulistus em tampão Tris- $\mathrm{HCl} 20 \mathrm{mmol} \mathrm{L}^{-1}(\mathrm{pH}$ 7,0), em função da concentração de CTAC, na região das bandas $Q$ (541 e 575) e na banda em $605 \mathrm{~nm}$.

Nas absorbâncias em $541 \mathrm{~nm}, 575 \mathrm{~nm}$ que são as bandas $Q$ houve uma diminuição em baixas concentrações de surfactantes, para concentrações mais elevadas, não se observou aumento e nem diminuição dessas bandas. $\mathrm{Na}$ banda em $605 \mathrm{~nm}$ observa-se um aumento de absorção até $0,4 \mu \mathrm{M}$, banda na qual é característica de formação de espécie pentacoordenada, devido a mudança na esfera de coordenação do ferro. 


\section{As mudanças espectrais observadas para baixas concentrações de}

CTAC sugerem uma contribuição significativa de interação eletrostática proteína-surfactante.

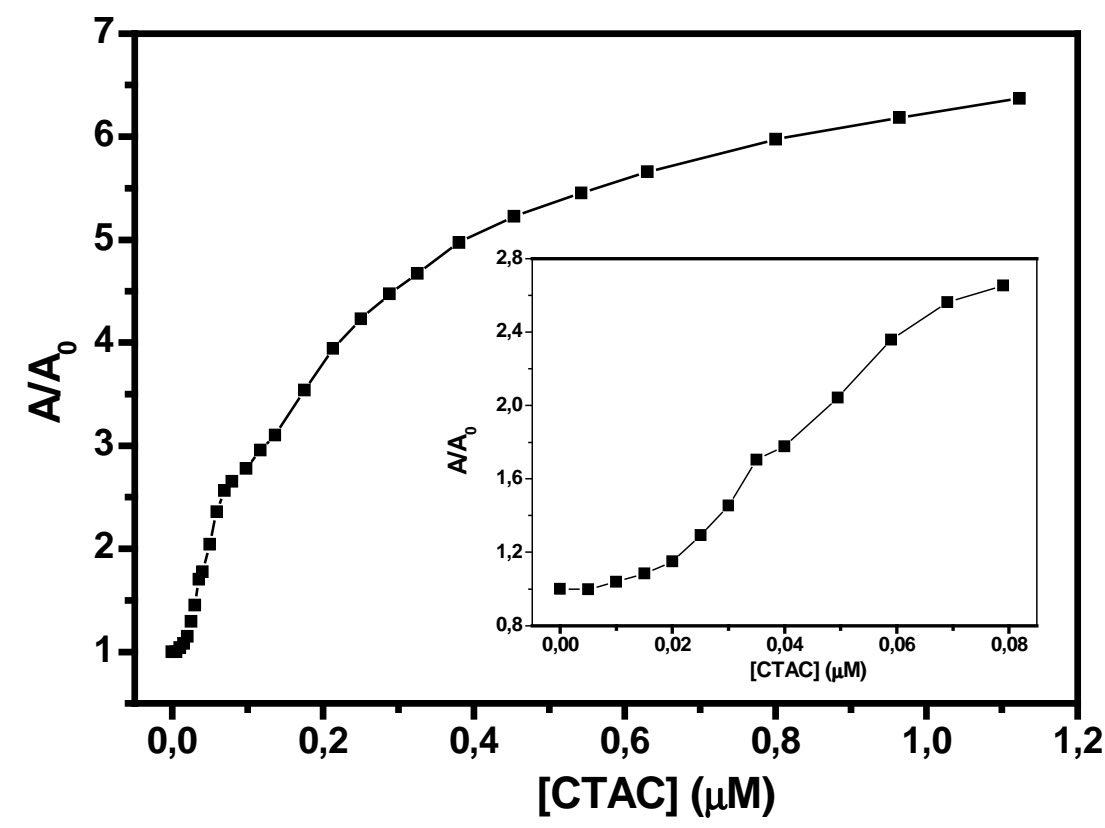

Figura 23: Áreas normalizadas dos espectros de emissão do oxi-monômero de G. paulistus em tampão Tris- $\mathrm{HCl} 20 \mathrm{mmol} \mathrm{L}^{-1}(\mathrm{pH} 7,0), \lambda_{\mathrm{exc}}=295 \mathrm{~nm}, \lambda_{\mathrm{em}}=305$ -450 nm, em função da concentração de CTAC.

A figura 23 ilustra a variação da fluorescência total normalizada pela fluorescência total do monômero na ausência de surfactante. As áreas foram previamente corrigidas em relação à variação da absorbância no comprimento de onda de excitação e em relação ao efeito de diluição devido às adições das alíquotas da solução estoque de CTAC. 
Na titulação do oxi-monômero pH 7,0 com CTAC identificou-se três fases. Inicialmente foi observado um aumento no máximo da fluorescência. Para se interpretar a intensificação da emissão, atribui-se à alteração da distância e/ou a uma mudança da orientação relativa dos resíduos de TRP em relação ao grupo heme. Para concentrações de CTAC até 0,079 $\mu \mathrm{M}$ ocorreu um aumento acentuado do rendimento quântico, devido a supressão de fluorescência dos resíduos de TRP. De forma geral pode-se propor interações iniciais das moléculas de CTAC em sítios aniônicos na cadeia polipeptídica do monômero. Após esta concentração de CTAC ocorrem transformações devido às interações com as moléculas de detergentes que podem provocar uma alteração na estrutura da cadeia polipeptídica desde a desnaturação da proteína até a formação da espécie pentacoordenada, alterando a fluorescência.

Para se extrair os parâmetros de interação do detergente com o oximonômero, o conjunto de espectros de fluorescência obtidos em função da concentração de CTAC (figura 24(A)) foi analisado empregando-se o método CCA (PERCZEL et al.1992) A análise foi feita considerando-se a variação espectral devido às transformações evolvendo três espécies químicas, e os espectros individuais destes componentes estão apresentados na figura 24(B). A decomposição do conjunto de espectros de emissão em duas componentes mostrou claramente que o modelo era inadequado sendo necessário adicionar mais uma componente. A primeira espécie centrada em $326 \mathrm{~nm}$ foi associada ao oxi-monômero puro. A segunda espécie centrada em $331 \mathrm{~nm}$ foi associada 
ao complexo oxi-monômero -CTAC (espécie pentacoordenada). A terceira espécie, centrada em 335 nm foi associada ao monômero desnaturado.

$\mathrm{Na}$ figura 24(C) estão apresentadas as contribuições, frações, de cada espécie no espectro experimental em função da concentração de CTAC. 

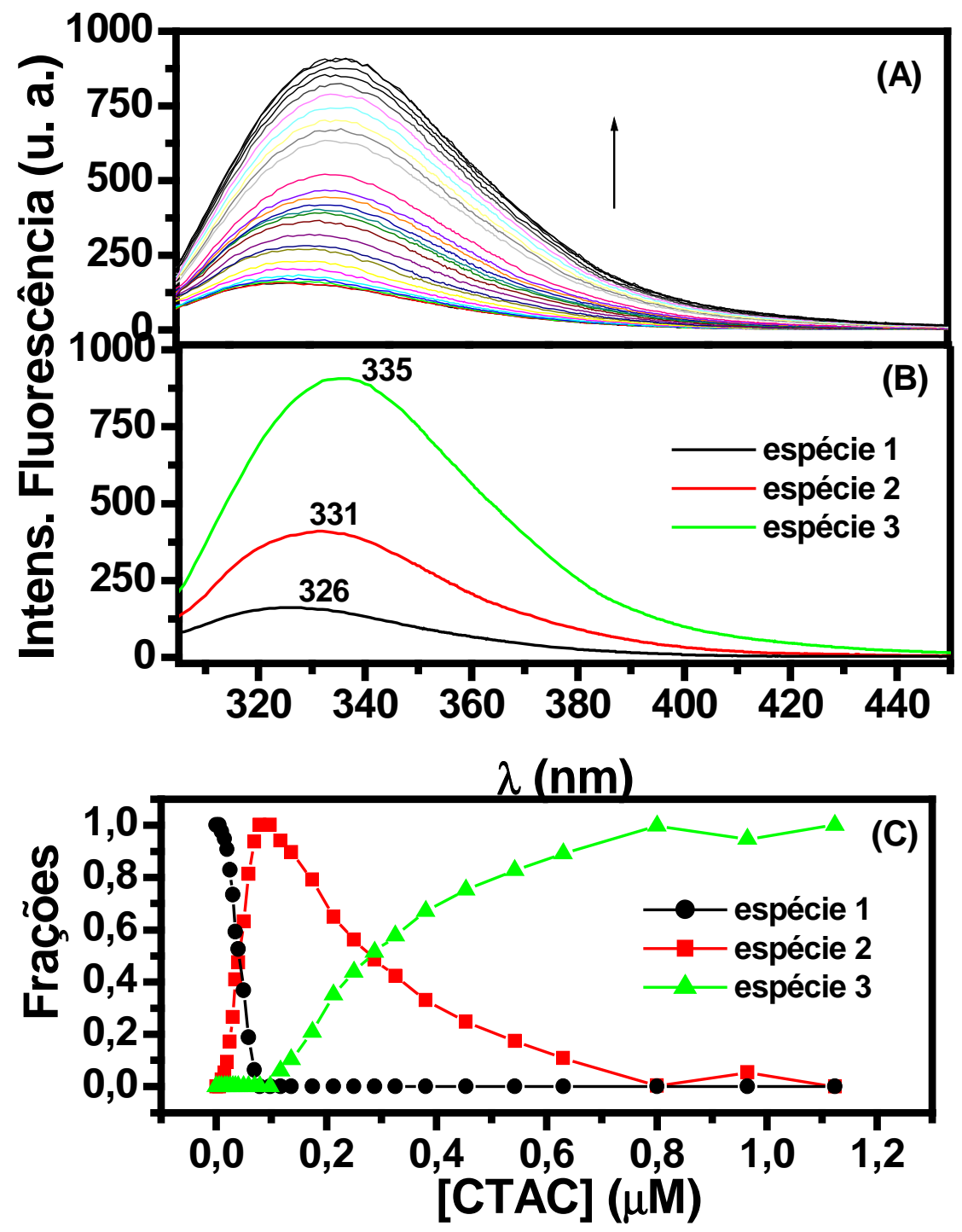

Figura 24: (A) Espectros de emissão do oxi-monômero de G. paulistus em tampão Tris- $\mathrm{HCl} 20 \mathrm{mmol} \mathrm{L}^{-1}(\mathrm{pH} 7,0), \lambda_{\text {exc }}=295 \mathrm{~nm}$ em função da concentração de CTAC, (B) espécies puras: oxi-monômero puro (-•-) - espécie 1, complexo monômero-CTAC (- - - - espécie 2 e monômero desnaturado (- - ) - espécie 3, correspondentes aos componentes dos espectros experimentais presentes em diferentes proporções; (C) conteúdo relativo de cada espécie em função da concentração de CTAC. 
4.1.4 Titulação do oxi-monômero da HbGp com CTAC em pH 9,0
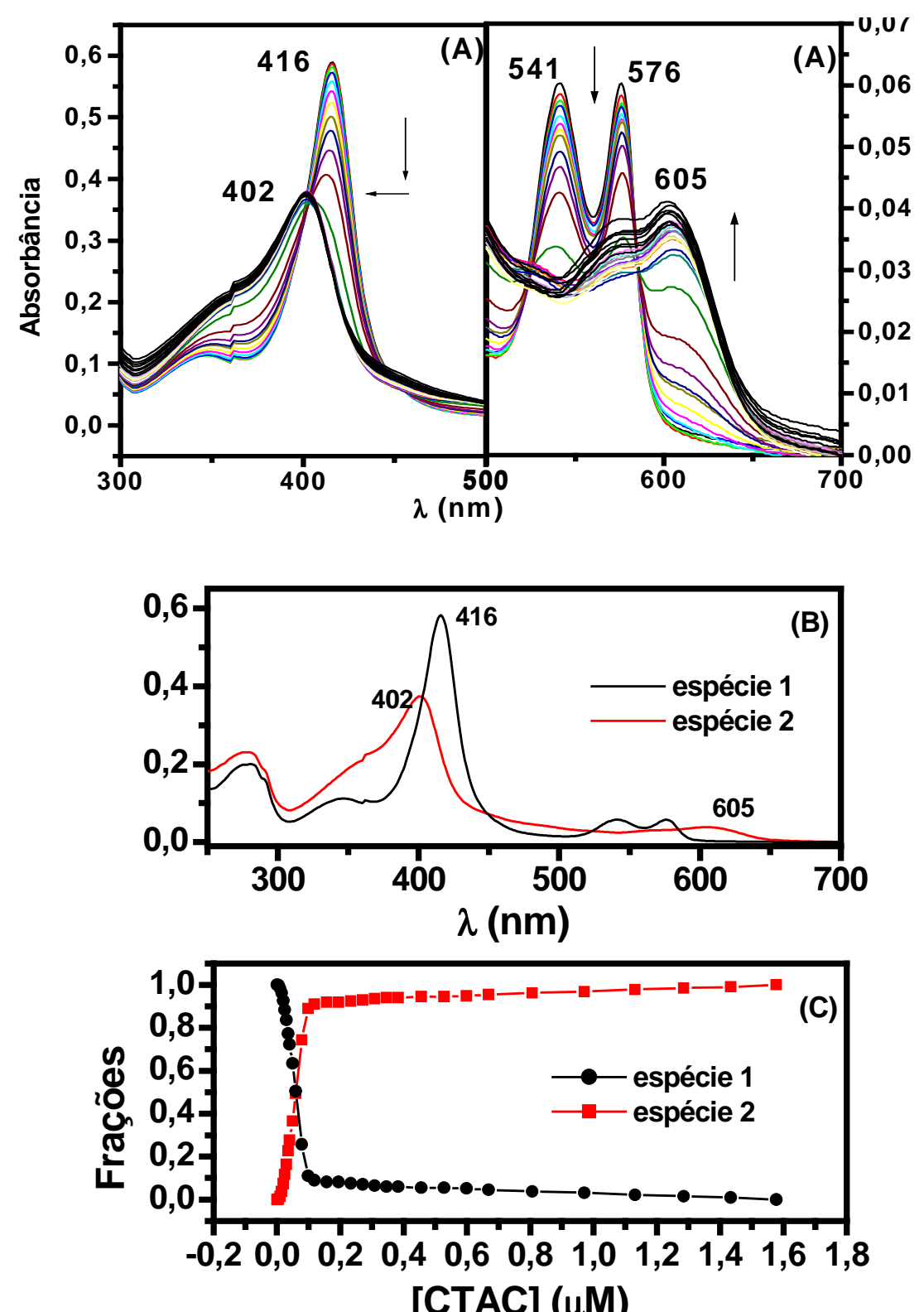

Figura 25: (A) Espectros de absorção UV-Vís do oxi-monômero de G. paulistus em tampão Tris-HCl 20 mmol L ${ }^{-1}$ (pH 9,0), função da concentração de CTAC na faixa de 0,005 - 1,6 $\mu \mathrm{M}$, (B) espécies puras: oxi-monômero puro (-๑-) - espécie 1, espécie pentacoordenada (- -) - espécie 2, correspondentes aos componentes dos espectros experimentais presentes em diferentes proporções; (C) conteúdo relativo de cada espécie em função da concentração de CTAC. 
Na figura 25(A) estão apresentados os espectros de absorção UV-Vís do oxi-monômero $d$ de G. paulistus em tampão Tris-HCl $20 \mathrm{mmol} \mathrm{L}^{-1}(\mathrm{pH} 9,0)$, função da concentração de CTAC, correspondente às transições eletrônicas $\pi$ $\rightarrow \pi^{*}$ do heme, onde a banda de Soret está centrada em $416 \mathrm{~nm}$, e as bandas $\alpha$ e $\beta$ possuem máximos, respectivamente, em $541 \mathrm{~nm}$ e $576 \mathrm{~nm}$, em pH 9,0. Este espectro é característico de oxi-hemoglobinas. Constatou-se, com a adição do surfactante CTAC, que ocorre uma diminuição da banda de Soret com deslocamento do máximo para 402 nm (figura 25(A)) bem como das bandas $\alpha$ (541 nm) e $\beta$ (576 nm). Além disso, surge uma banda em $605 \mathrm{~nm}$ referente ao surgimento de uma espécie de pentacoordenada. (MOREIRA, 2006)(GILLESGONZALEZ et al.1994)(PIETRI et al.2005). Segundo Santiago e col (SANTIAGO et al.2007) esta espécie se forma pelo fato que o CTAC por ser um surfactante catiônico, ou seja, se liga a sítios específicos carregados negativamente, proporciona a ligação aos resíduos de aminoácidos aniônicos como glutamil e aspartil (TURRO e LEI, 1995), provocando uma grande distorção na cadeia polipeptídica, ocorrendo assim uma distorção no grupo heme e com isso a ligação do nitrogênio do imidazol da histidina proximal F8, ou seja, oitavo resíduo da hélice $F$ se rompa formando a espécie pentacoordenada.

Empregando-se o algoritmo CCA (PERCZEL et al.1992) através do emprego de duas bases obtendo-se os espectros representados na figura 25(B). Estes espectros foram atribuídos às duas espécies químicas em solução: oxi-monômero puro, espécie 1 e espécie pentacoordenada, espécie 2). 
Na figura 25(C) são apresentadas as frações de cada espécie em função da adição de CTAC.

É possível observar através das figuras $25 \mathrm{C}$ e 20C, a interação do CTAC com o monômero $d$ de HbGp foi mais efetiva em $\mathrm{pH} \mathrm{9,0} \mathrm{que} \mathrm{em} \mathrm{pH} 7,0$. Para $0,1 \mu \mathrm{M}$ de CTAC em $\mathrm{pH} 7,0$ (figura $20(\mathrm{C})$ ), se observa $60 \%$ da espécie pentacoordenada, e para $0,1 \mu \mathrm{M}$ de CTAC em pH 9,0 já se observa aproximadamente $90 \%$ da espécie pentacoordenada. A interação do monômero $d$ com CTAC também foi mais efetiva em relação ao SDS. A efetividade da interação em pH 9,0 com o CTAC pode ser explicada pelo pl da proteína.

Hemoglobinas extracelulares apresentam o ponto isoelétrico ácido, desta forma, em meio alcalino apresentam maior número de sítios aniônicos na sua cadeia para interagir com o surfactante catiônico. O monômero $d$ da HbGp deve seguir o mesmo comportamento para o valor de pl. Santiago et al. 2007, em estudos mcom a HbGp íntegra, observaram uma interação mais efetiva para o sistema HbGp-CTAC em pH 7,0.

Nas figuras 26 e 27 estão apresentados os gráficos de absorbância em função da concentração de CTAC (máximos analisados: 416 nm, 541 nm, 575 $\mathrm{nm}$ e $605 \mathrm{~nm})$.

A absorbância em 416 nm (banda de Soret) diminui com o aumento da concentração de surfactantes, ou seja, até a concentração $0,34 \mu \mathrm{M}$ tem-se a diminuição acentuada da banda, permanecendo constante até a concentração 1 $\mu \mathrm{M}$. 


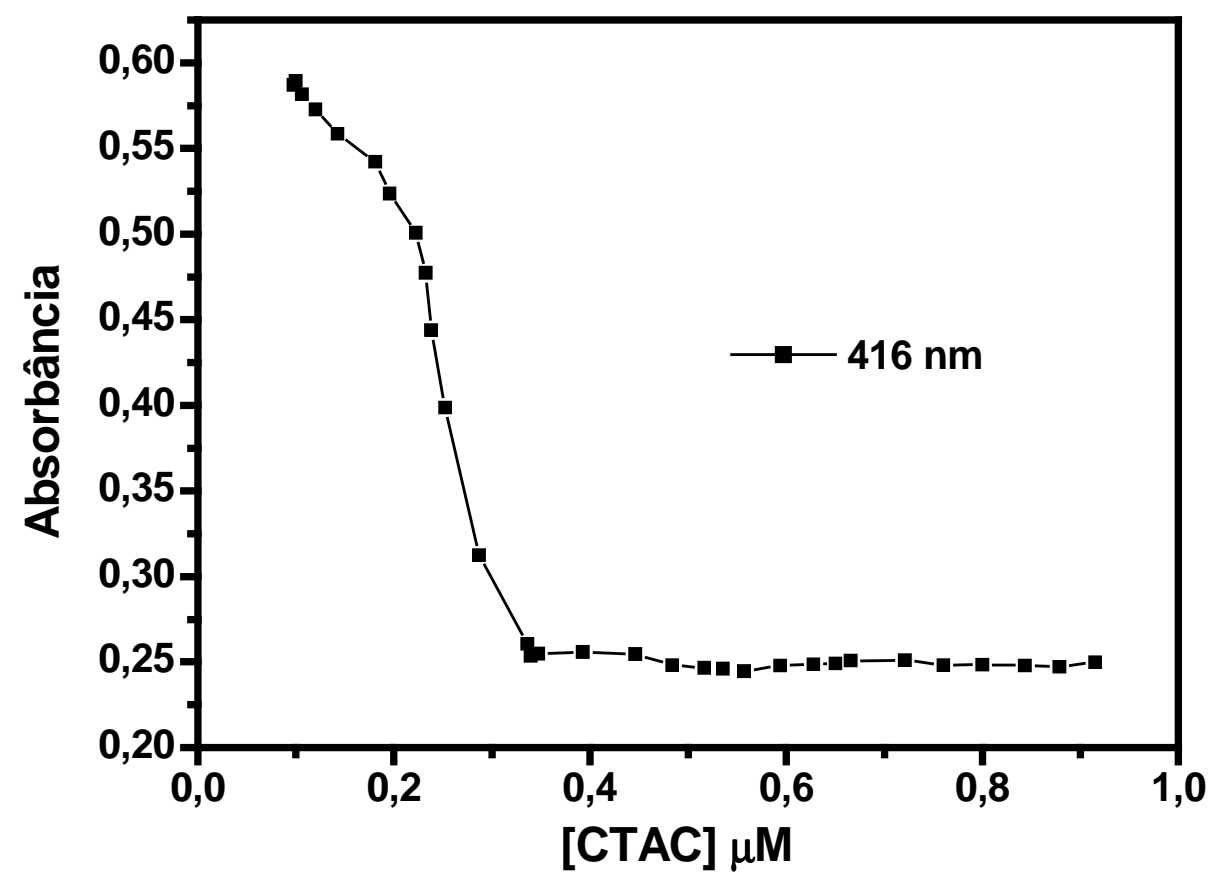

Figura 26: Gráfico de absorbância do oxi-monômero de G. paulistus em tampão Tris-HCl $20 \mathrm{mmol} \mathrm{L}^{-1}$ (pH 9,0), em função da concentração de CTAC, na região da banda de Soret.

Nas absorbâncias em $541 \mathrm{~nm}, 575 \mathrm{~nm}$ que são as bandas $Q$ houve uma diminuição em baixas concentrações de surfactantes, para concentrações mais elevadas, não se observou nem aumento e nem diminuição do máximo de absorção. Na banda em $605 \mathrm{~nm}$ observa-se um aumento de absorção até 0,34 $\mu \mathrm{M}$, banda na qual é característica de formação de espécie pentacoordenada, devido a mudança na esfera de coordenação do ferro. 


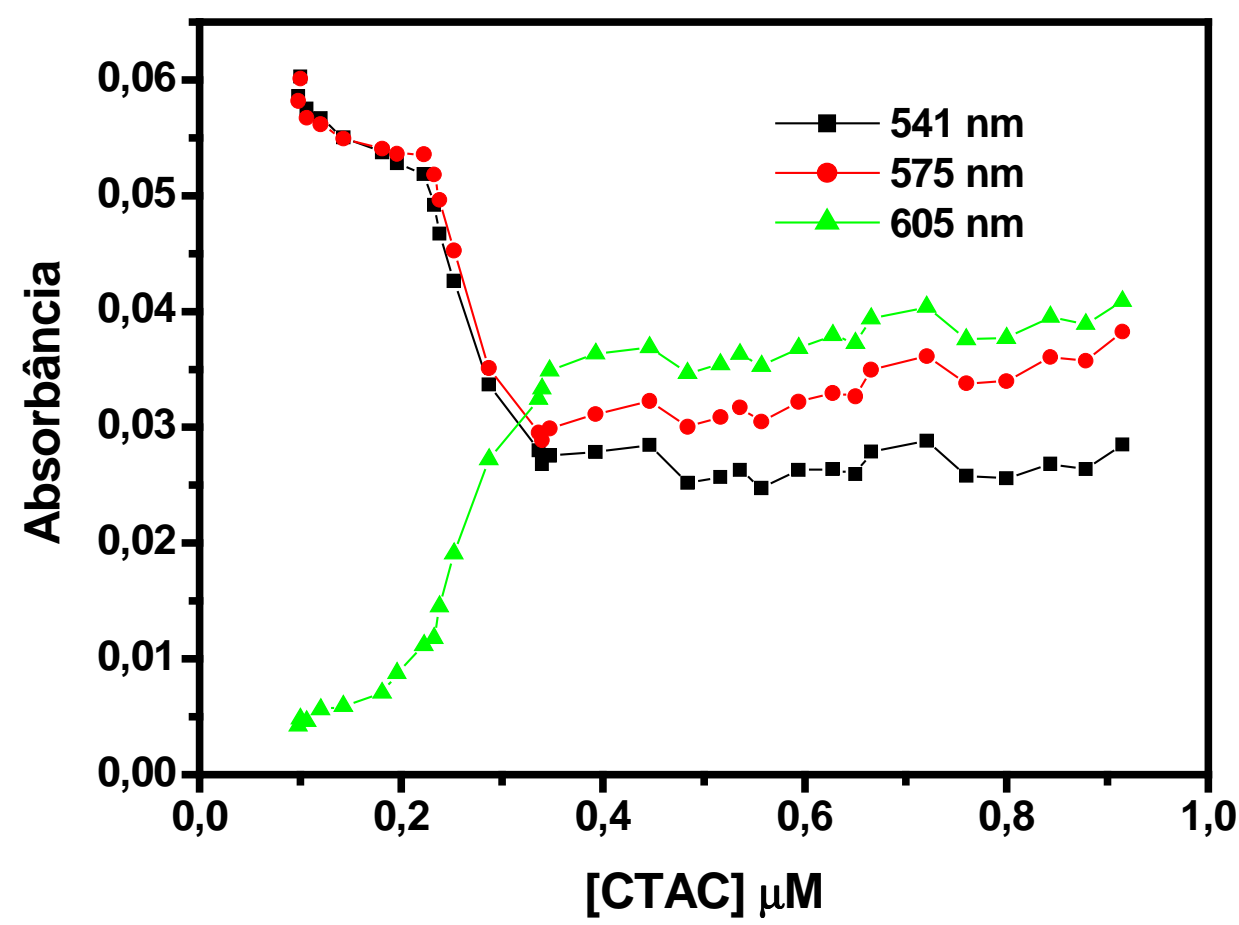

Figura 27: Gráfico de absorbância do oxi-monômero de G. paulistus em tampão Tris-HCl $20 \mathrm{mmol} \mathrm{L}^{-1}$ (pH 9,0), em função da concentração de CTAC, na região das bandas $Q(541$ e 575$)$ e na banda em 605 nm.

As mudanças espectrais observadas para baixas concentrações de CTAC sugerem uma contribuição significativa de interação eletrostática proteína-surfactante.

Pode-se constatar que até a concentração de $0,34 \mu \mathrm{M}$, observa-se que a banda de Soret e as bandas $\mathrm{Q}$ diminuíram bruscamente e a banda em 605 nm surgiu, ou seja, nesta concentração de CTAC observa-se a formação da espécie pentacoordenada. 
Na titulação do oxi-monômero pH 9,0 com CTAC identificou-se três fases (figura 28). Inicialmente foi observado um aumento no máximo da fluorescência. Para se interpretar a intensificação da emissão, atribui-se à alteração da distância e/ou a uma mudança da orientação relativa dos resíduos de TRP em relação ao grupo heme. Para concentrações de CTAC até $0,035 \mu \mathrm{M}$ ocorreu um aumento acentuado do rendimento quântico, devido a supressão de fluorescência dos resíduos de TRP. De forma geral pode-se propor interações iniciais das moléculas de CTAC em sítios aniônicos na cadeia polipeptídica do monômero. Para concentrações de 0,040-0,157 $\mu \mathrm{M}$ corresponde ao complexo monômero-surfactante. Após esta concentração de CTAC ocorrem transformações devido às interações com as moléculas de detergentes que podem provocar uma alteração na estrutura da cadeia polipeptídica desde a desnaturação da proteína até a formação da espécie pentacoordenada, alterando a fluorescência. 


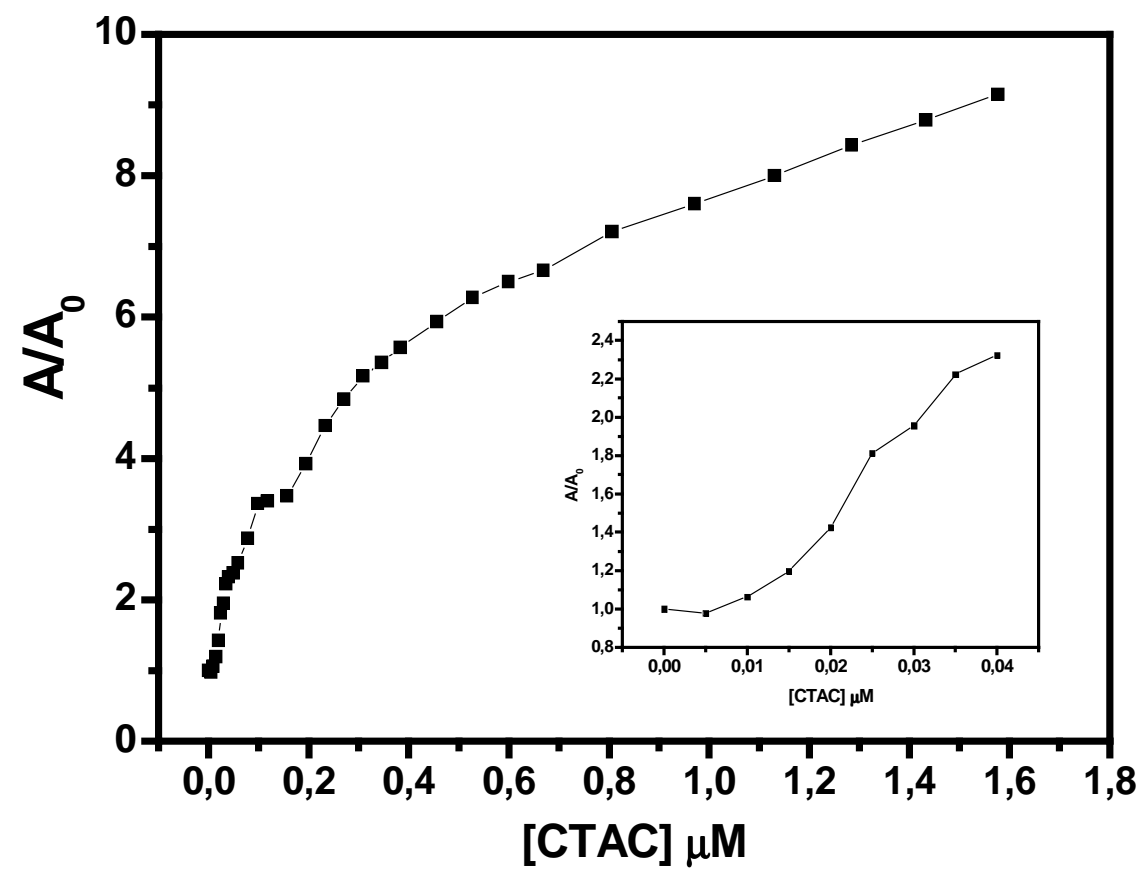

Figura 28: Áreas normalizadas dos espectros de emissão do oxi-monômero de G. paulistus em tampão Tris- $\mathrm{HCl} 20 \mathrm{mmol} \mathrm{L}^{-1}(\mathrm{pH} 9,0), \lambda_{\mathrm{exc}}=295 \mathrm{~nm}, \lambda_{\mathrm{em}}=305$ -450 nm, em função da concentração de CTAC.

$\mathrm{Na}$ figura 29(A), a primeira espécie centrada em $327 \mathrm{~nm}$ foi associada ao oxi-monômero puro. A segunda espécie centrada em $329 \mathrm{~nm}$ foi associada ao complexo oxi-monômero -CTAC (espécie pentacoordenada). A terceira espécie, centrada em $335 \mathrm{~nm}$ foi associada ao monômero desnaturado.

$\mathrm{Na}$ figura $29(\mathrm{C})$ estão apresentadas às contribuições, frações, de cada espécie no espectro experimental em função da concentração de CTAC. 

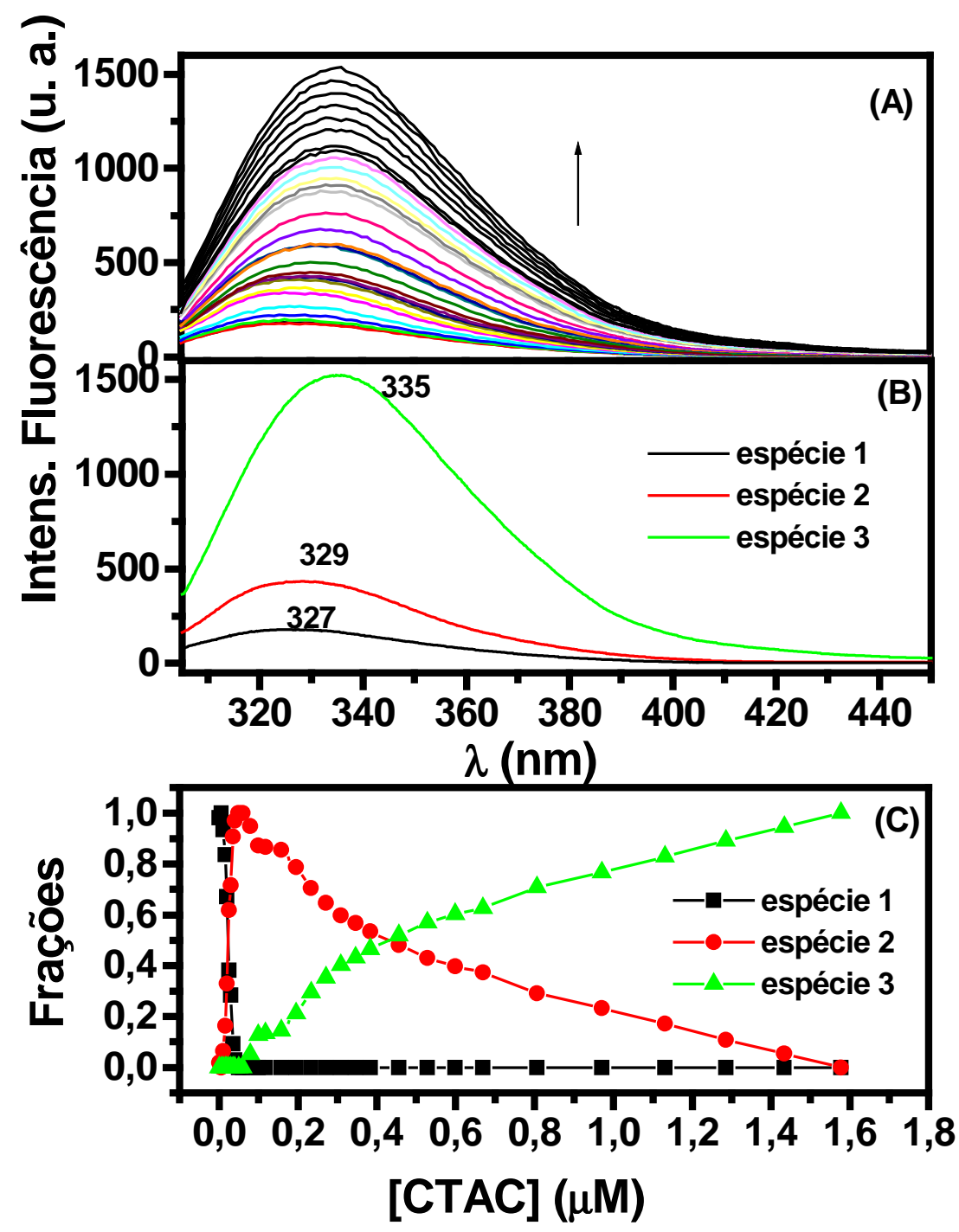

Figura 29: (A) Espectros de emissão do oxi-monômero de G. paulistus em tampão Tris- $\mathrm{HCl} 20 \mathrm{mmol}^{-1}(\mathrm{pH} 9,0), \quad \lambda_{\mathrm{exc}}=295 \mathrm{~nm}$ em função da concentração de CTAC, (B) espécies puras: oxi-monômero puro (-m-) - espécie 1, complexo monômero-CTAC $(-\bullet)$ - espécie 2 e monômero desnaturado $(-\Delta-)$ - espécie 3, correspondentes aos componentes dos espectros experimentais presentes em diferentes proporções; (C) conteúdo relativo de cada espécie em função da concentração de CTAC. 
4.1.5 Titulação do oxi-monômero da HbGp com BRIJ-35 em pH 7,0
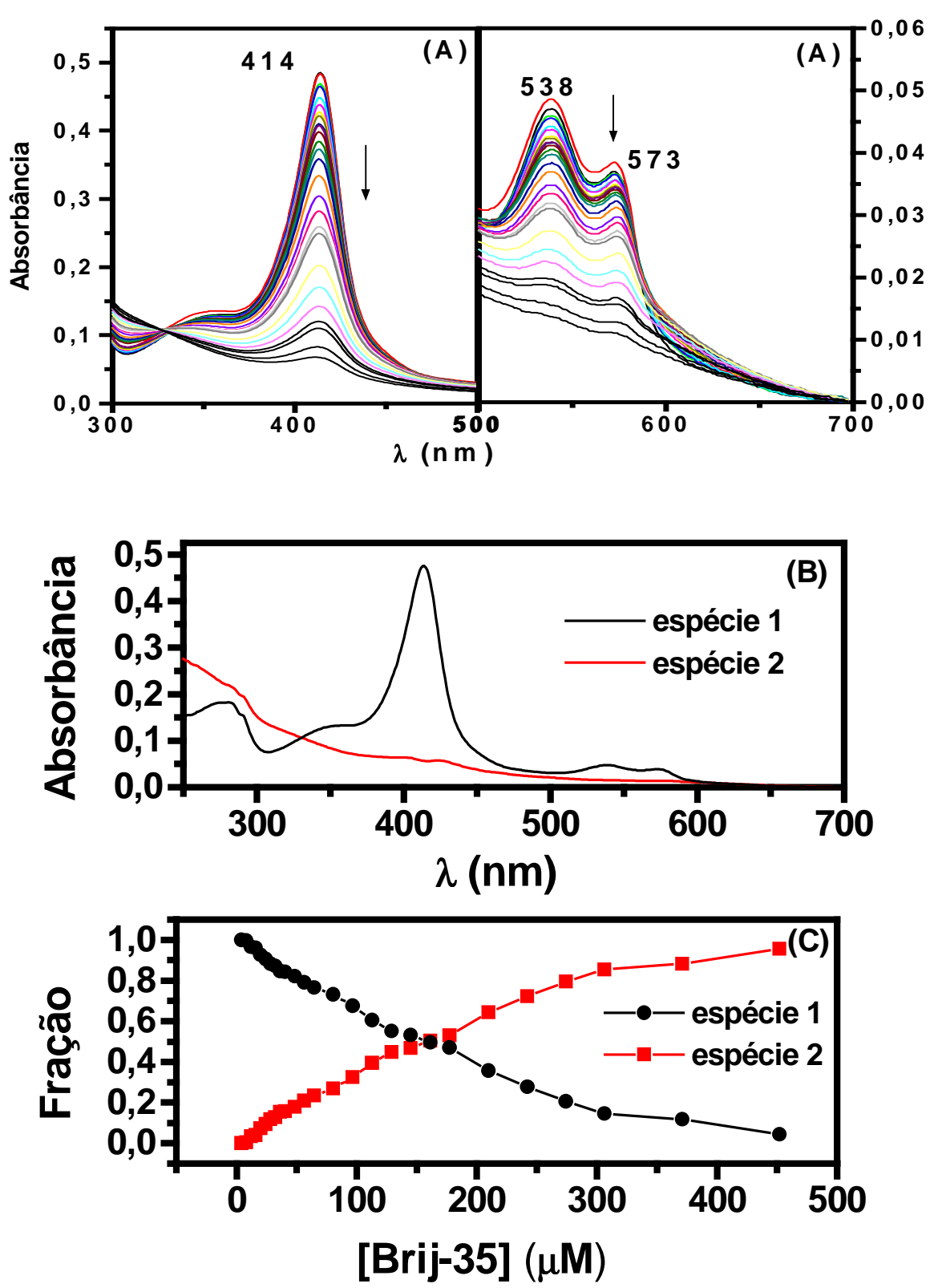

Figura 30: (A) Espectros absorção UV-Vís do oxi-monômero de G. paulistus em

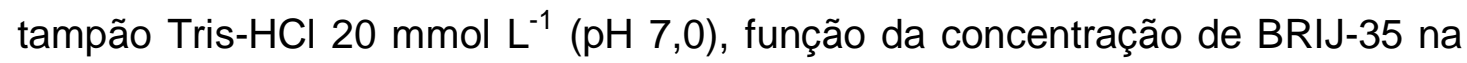
faixa de 4,0 - $452 \mu \mathrm{M}$, (B) espécies puras: oxi-monômero puro (-๑-) - espécie 1, oxi-monômero desnaturado (-口-) - espécie 2, correspondentes aos componentes dos espectros experimentais presentes em diferentes proporções; (C) conteúdo relativo de cada espécie em função da concentração de BRIJ-35. 
Os espectros de absorção UV-Vís do monômero $d$ da Hb de G. paulistus o qual foi obtido por dissociação alcalina em pH 9,0, foram analisados na região entre 700 nm e 250 nm, em função da adição do surfactante BRIJ-35.

$\mathrm{Na}$ figura 30(A) estão apresentados os espectros óticos do monômerooxi $d$ de $G$. paulistus, correspondente às transições eletrônicas $\pi \rightarrow \pi^{\star}$ do heme, onde a banda de Soret está centrada em $414 \mathrm{~nm}$, e as bandas $\alpha$ e $\beta$ possuem máximos, respectivamente, em 538 nm e 573 nm, em pH 7,0.

Constatou-se, com a adição do surfactante, que ocorre uma diminuição muito intensa da banda de Soret (Figura 30(A)) bem como das bandas a (538 $\mathrm{nm})$ e $\beta(573 \mathrm{~nm})$.

Empregando-se o algoritmo CCA (PERCZEL et al.1992) através do emprego de duas bases obtendo-se os espectros representados na figura 30(B). Estes espectros foram atribuídos às duas espécies químicas em solução: oxi-monômero puro, espécie 1 e espécie desnaturada, espécie 2).

Na figura 30(C) são apresentadas as frações de cada espécie em função da adição de BRIJ-35.

Conforme observamos para os experimentos com o surfactante CTAC em $\mathrm{pH} 7,0$ e 9,0, a formação de espécies pentacoordenadas que é caracterizada pela formação de banda em 605 nm e a diminuição do máximo de absorção da banda de Soret e o seu deslocamento para menores comprimentos de onda, não foi observado no caso do BRIJ-35. 
Nas figuras 31 e 32 estão apresentados os gráficos de absorbância em função da concentração de BRIJ-35 (máximos analisados: 414 nm, 538 nm, 576 $\mathrm{nm})$.

A absorbância em $414 \mathrm{~nm}$ (banda de Soret) diminui com o aumento da concentração de surfactante.

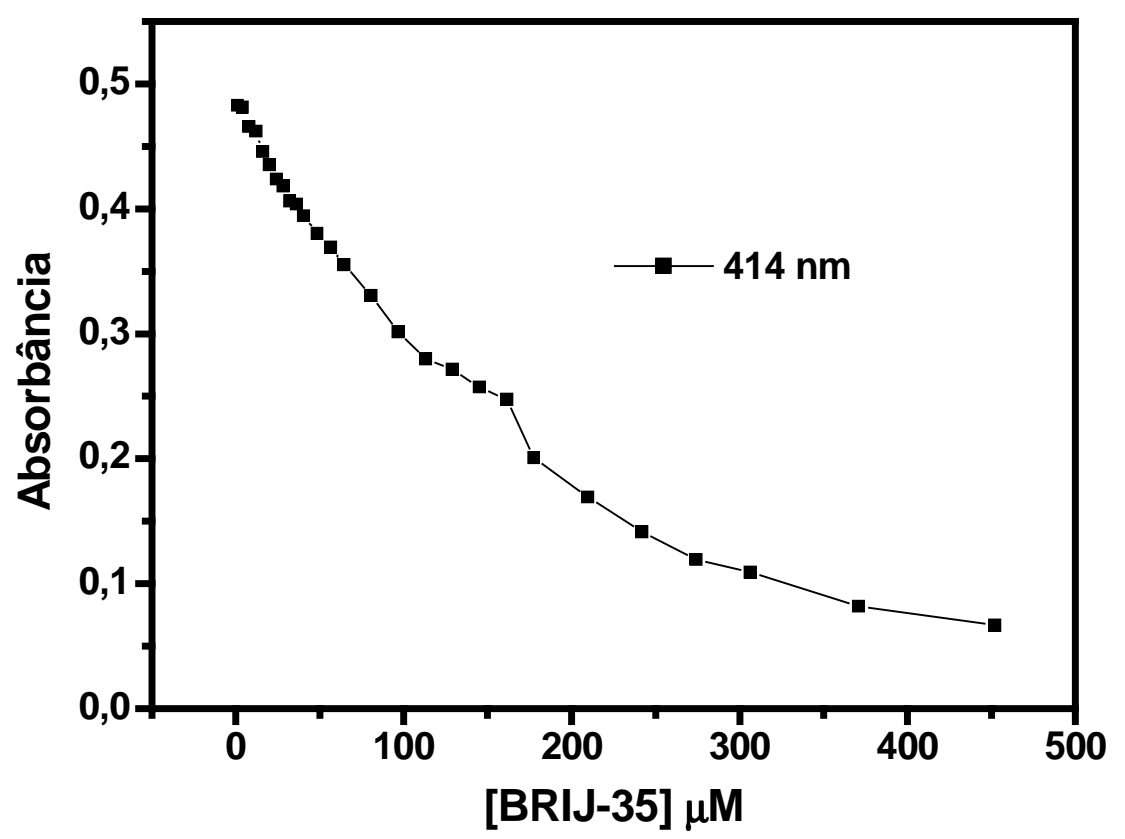

Figura 31: Gráfico de absorbância do oxi-monômero de G. paulistus em tampão Tris-HCl $20 \mathrm{mmol} \mathrm{L}^{-1}$ (pH 7,0), em função da concentração de BRIJ-35, na região da banda de Soret. 
Nas absorbâncias em 538 nm, 576 nm houve uma diminuição dos máximos de absorbância com a adição de surfactantes, para concentrações mais elevadas de surfactantes ocorre a desnaturação completa do monômero $d$ da hemoglobina de G. paulistus.

As mudanças espectrais observadas sugerem uma contribuição significativa de interação eletrostática proteína-surfactante.

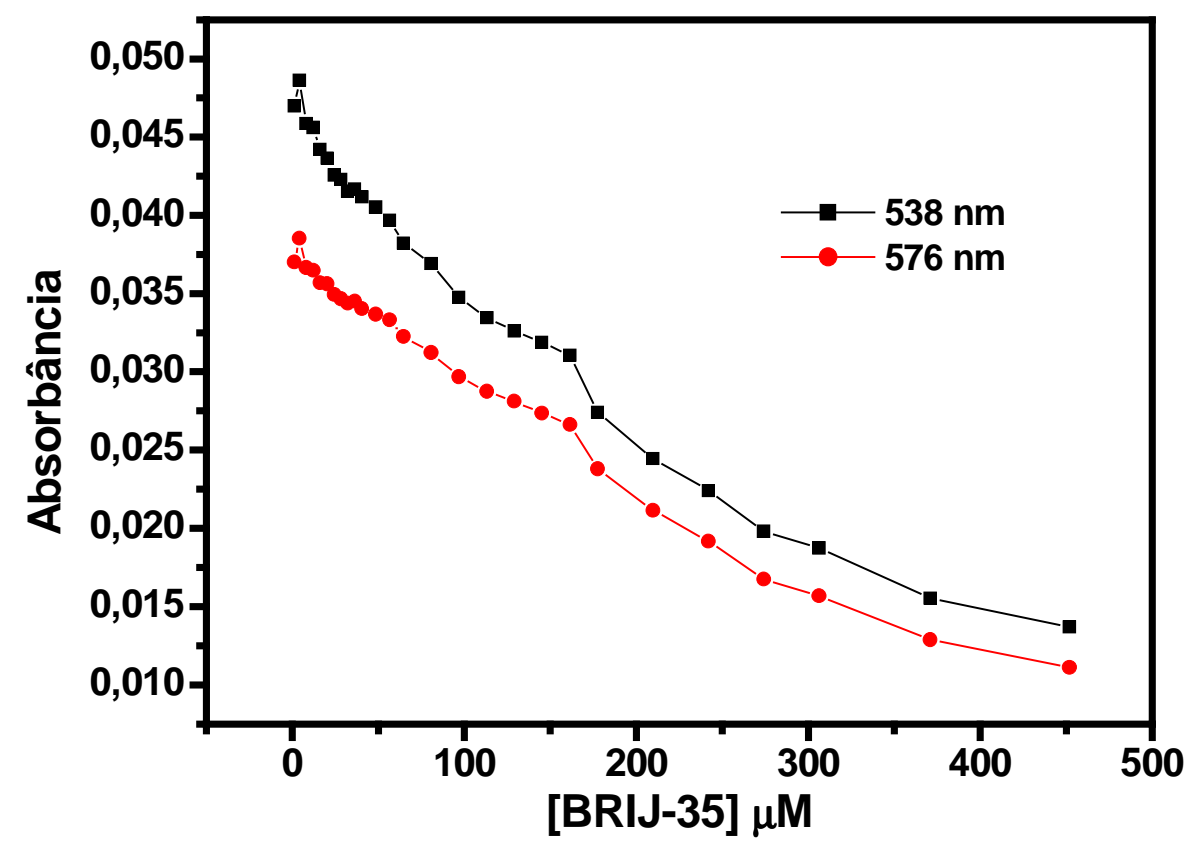

Figura 32: Gráfico de absorbância do oxi-monômero de G. paulistus em tampão Tris-HCl 20 mmol L-1 (pH 7,0), em função da concentração de BRIJ-35, na região das bandas Q, $538 \mathrm{~nm}$ e $576 \mathrm{~nm}$, respectivamente. 


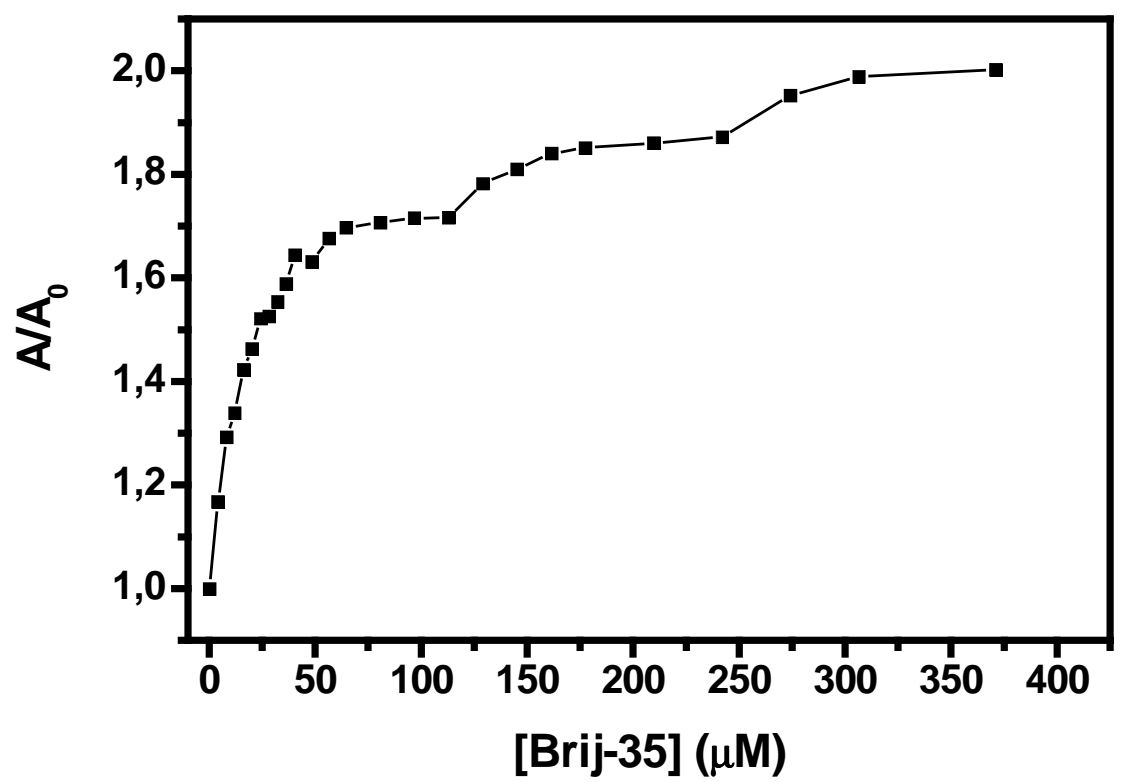

Figura 33: Áreas normalizadas dos espectros de emissão do oxi-monômero de G. paulistus em tampão Tris- $\mathrm{HCl} 20 \mathrm{mmol} \mathrm{L}^{-1}(\mathrm{pH} 7,0), \lambda_{\mathrm{exc}}=295 \mathrm{~nm}, \lambda_{\mathrm{em}}=305$ $-450 \mathrm{~nm}$, em função da concentração de BRIJ-35.

A figura 33 ilustra a variação da fluorescência total (A, área sob a curva de emissão) normalizada pela fluorescência total do monômero na ausência de surfactante, $A_{0}$. As áreas foram previamente corrigidas em relação à variação da absorbância no comprimento de onda de excitação e em relação ao efeito de diluição devido às adições das alíquotas da solução estoque de BRIJ-35.

Na titulação do oxi-monômero pH 7,0 com BRIJ-35 identificou-se três fases. Inicialmente foi observado um aumento no máximo da fluorescência até a concentração de $113 \mu \mathrm{M}$ de BRIJ-35. Para se interpretar a intensificação da emissão, atribui-se à alteração da distância e/ou a uma 
mudança da orientação relativa dos resíduos de TRP em relação ao grupo heme. Para concentrações de BRIJ-35 até $242 \mu \mathrm{M}$ de BRIJ-35 observou-se um aumento de fluorescência, e por fim outro aumento de fluorescência ate a concentração $371 \mu \mathrm{M}$ de BRIJ-35 (figura 33). Como o BRIJ-35 é um a molécula de surfactante que possui uma porção polar, ou seja, hidrofóbica, e uma porção apolar (hidrofílica) sem carga, de forma geral pode-se propor que o aumento da fluorescência esta relacionado com a entrada da cadeia hidrofóbica no bolsão do heme, provocando uma desorganização nas cadeias protéicas do oxi-monômero.

Para se extrair os parâmetros de interação do detergente com o oximonômero, o conjunto de espectros de fluorescência obtidos em função da concentração de BRIJ-35 (figura 34(A)) foi analisado empregando-se o método CCA (PERCZEL et al.1992) A análise foi feita considerando-se a variação espectral devido às transformações evolvendo três espécies químicas, e os espectros individuais destes componentes estão apresentados na figura 34(B). A primeira espécie centrada em $331 \mathrm{~nm}$ foi associada ao oxi-monômero puro. A segunda espécie centrada em $330 \mathrm{~nm}$ foi associada ao complexo oximonômero -BRIJ-35 predominante na faixa de $113 \mu \mathrm{M}-242 \mu \mathrm{M}$. A terceira espécie, centrada em 334 nm foi associada ao monômero desnaturado e é a única espécie até $400 \mu \mathrm{M}$ de BRIJ-35. Na figura 34(C) estão apresentadas as contribuições, frações, de cada espécie no espectro experimental em função da concentração de BRIJ-35. 

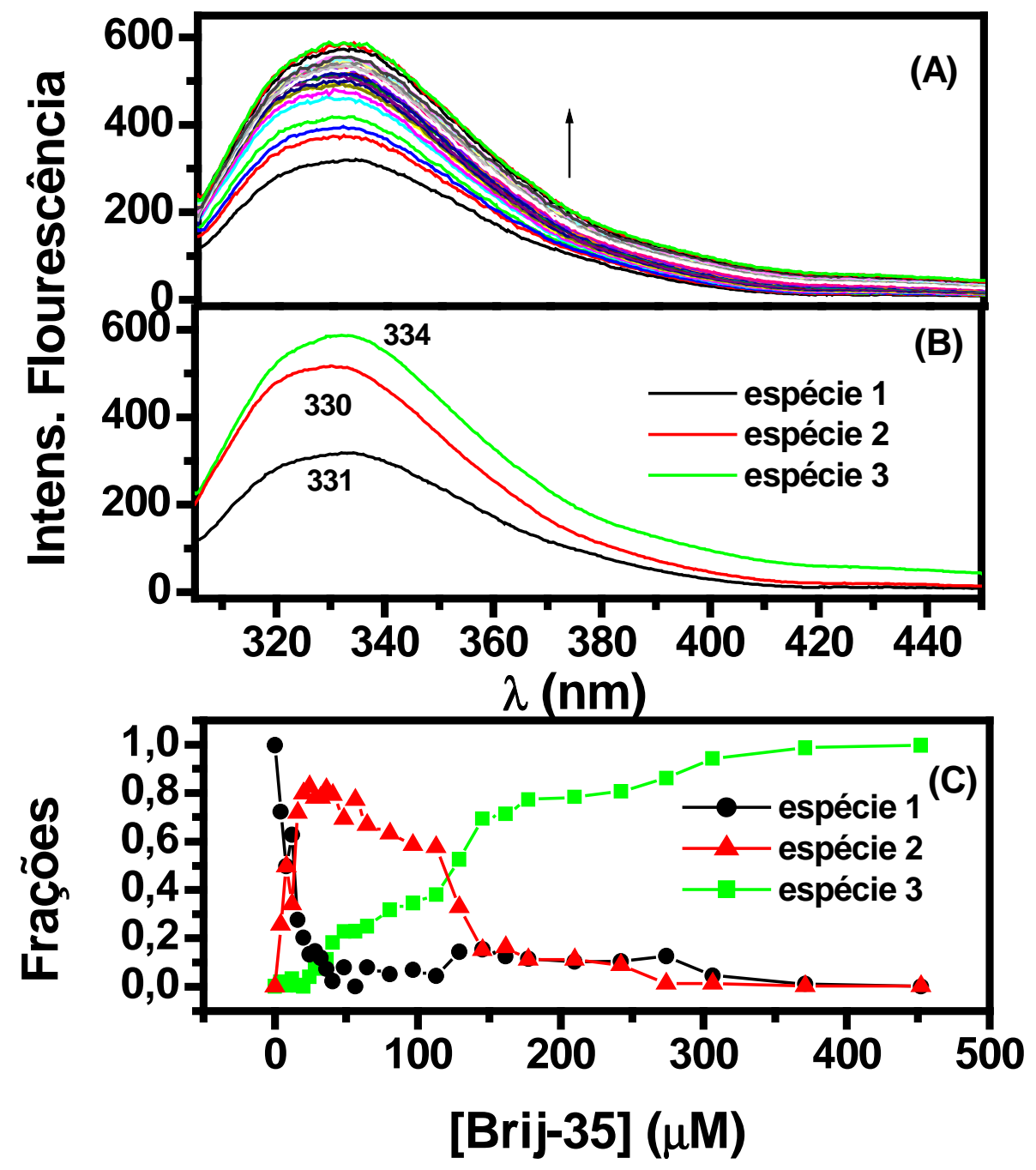

Figura 34: (A) Espectros de emissão do oxi-monômero de G. paulistus em tampão Tris- $\mathrm{HCl} 20 \mathrm{mmol} \mathrm{L} \mathrm{L}^{-1}(\mathrm{pH} 7,0), \lambda_{\text {exc }}=295 \mathrm{~nm}$ em função da concentração de BRIJ-35, (B) espécies puras: oxi-monômero puro (-•-) espécie 1, complexo monômero-BRIJ-35 (- $\left.\mathbf{\Lambda}^{-}\right)$- espécie 2 e monômero desnaturado (--) - espécie 3, correspondentes aos componentes dos espectros experimentais presentes em diferentes proporções; (C) conteúdo relativo de cada espécie em função da concentração de BRIJ-35. 


\subsubsection{Titulação do oxi-monômero da HbGp com BRIJ-35 em pH 9,0}
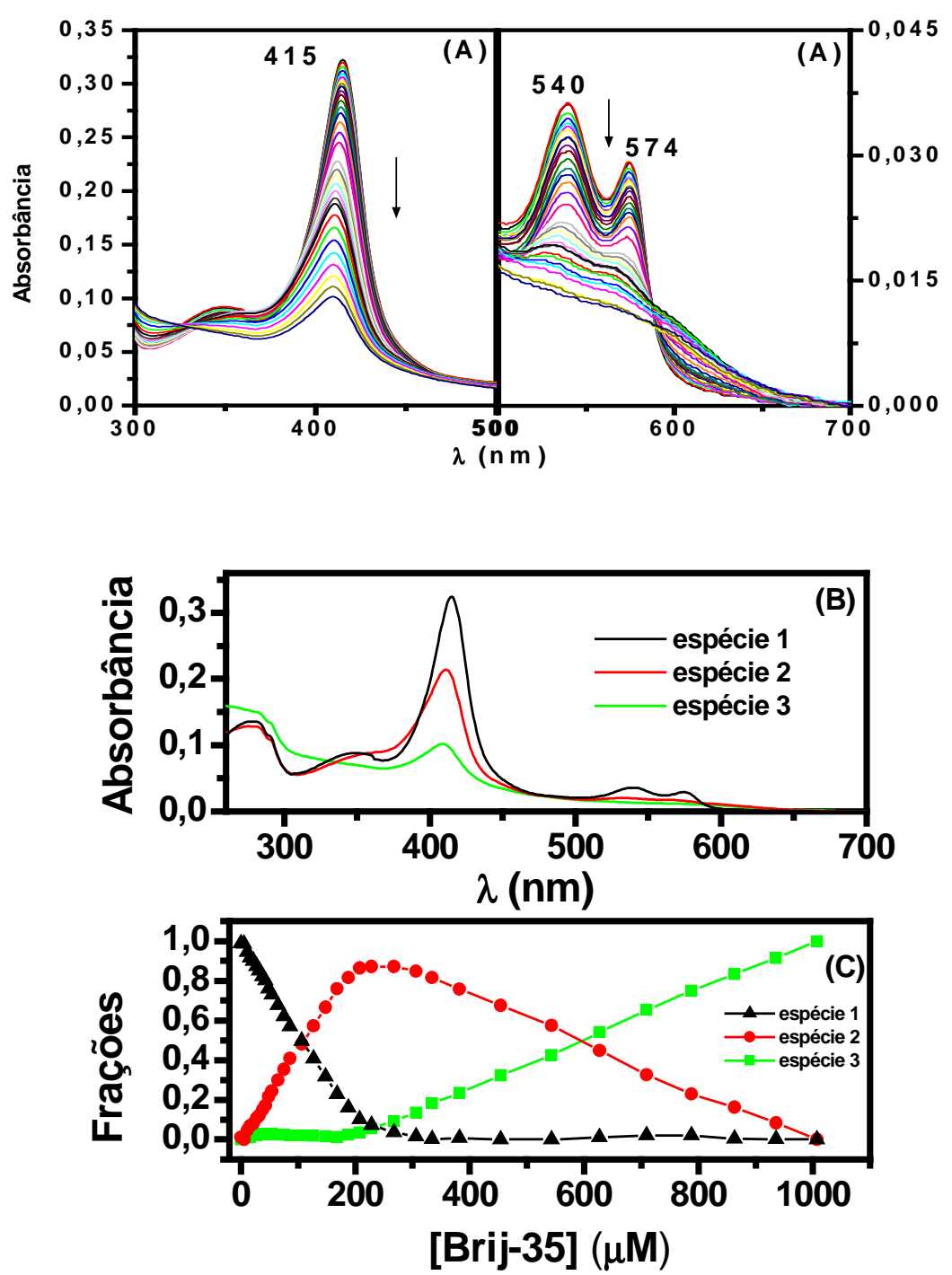

Figura 35: (A) Espectros de absorção UV-Vís do oxi-monômero de G. paulistus em tampão Tris-HCl 20 mmol L-1 $(\mathrm{pH} 9,0)$, função da concentração de BRIJ-35 na faixa de 5,4-1007 $\mu \mathrm{M}$, (B) espécies puras: oxi-monômero puro (- $\mathbf{\Delta}$-) espécie 1, complexo monômero-surfactante (-๑-) - espécie 2, monômero desnaturado (-n-) - espécie 3, correspondentes aos componentes dos espectros experimentais presentes em diferentes proporções; (C) conteúdo relativo de cada espécie em função da concentração de BRIJ-35. 
Os espectros de absorção UV-Vís do monômero $d$ da Hb de G. paulistus o qual foi obtido por dissociação alcalina em pH 9,0, foram analisados na região entre 700 nm e 250 nm, em função da adição do surfactante BRIJ-35.

$\mathrm{Na}$ figura 35(A) estão apresentados os espectros óticos do oximonômero $d$ de G. paulistus, correspondente às transições eletrônicas $\pi \rightarrow \pi^{*}$ do heme, onde a banda de Soret está centrada em $415 \mathrm{~nm}$, e as bandas $\alpha$ e $\beta$ possuem máximos, respectivamente, em 540 nm e 574 nm, em pH 9,0.

Constatou-se, com a adição do surfactante, que ocorre uma diminuição muito intensa da banda de Soret (Figura 35(A)) bem como das bandas a (540 $\mathrm{nm})$ e $\beta(574 \mathrm{~nm})$.

Empregando-se o algoritmo CCA (PERCZEL et al.1992) através do emprego de três bases obtendo-se os espectros representados na figura 35(B). Estes espectros foram atribuídos a três espécies químicas em solução: oximonômero puro, espécie 1, complexo oxi-monômero - BRIJ-35, espécie 2 e monômero desnaturado, espécie 3).

Na figura 35(C) são apresentadas às frações de cada espécie em função da adição de CTAC.

Nas figuras 36 e 37 estão apresentados os gráficos de absorbância em função da concentração de BRIJ-35 (máximos analisados: 415 nm, 540 nm, 574 $\mathrm{nm})$.

A absorbância em 415 nm (banda de Soret) diminui com o aumento da concentração de surfactante. 


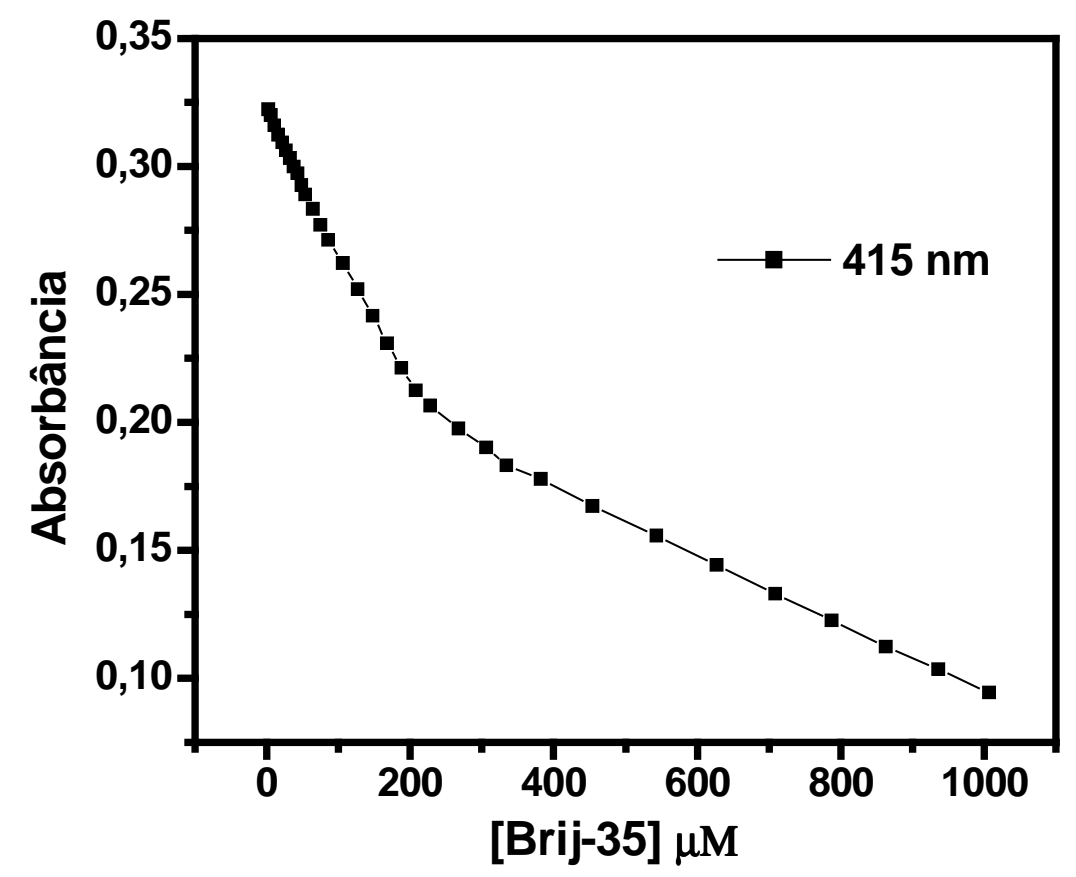

Figura 36: Gráfico de absorbância do oxi-monômero de G. paulistus em tampão Tris-HCl $20 \mathrm{mmol} \mathrm{L}^{-1}$ (pH 9,0), em função da concentração de BRIJ-35, na região da banda de Soret.

Nas absorbâncias em 540 nm, 574 nm houve uma diminuição dos máximos de absorbância com a adição de surfactantes, para concentrações mais elevadas de surfactantes ocorre a desnaturação completa do monômero $d$ da hemoglobina de G. paulistus.

As mudanças espectrais observadas sugerem uma contribuição significativa de interação eletrostática proteína-surfactante. 


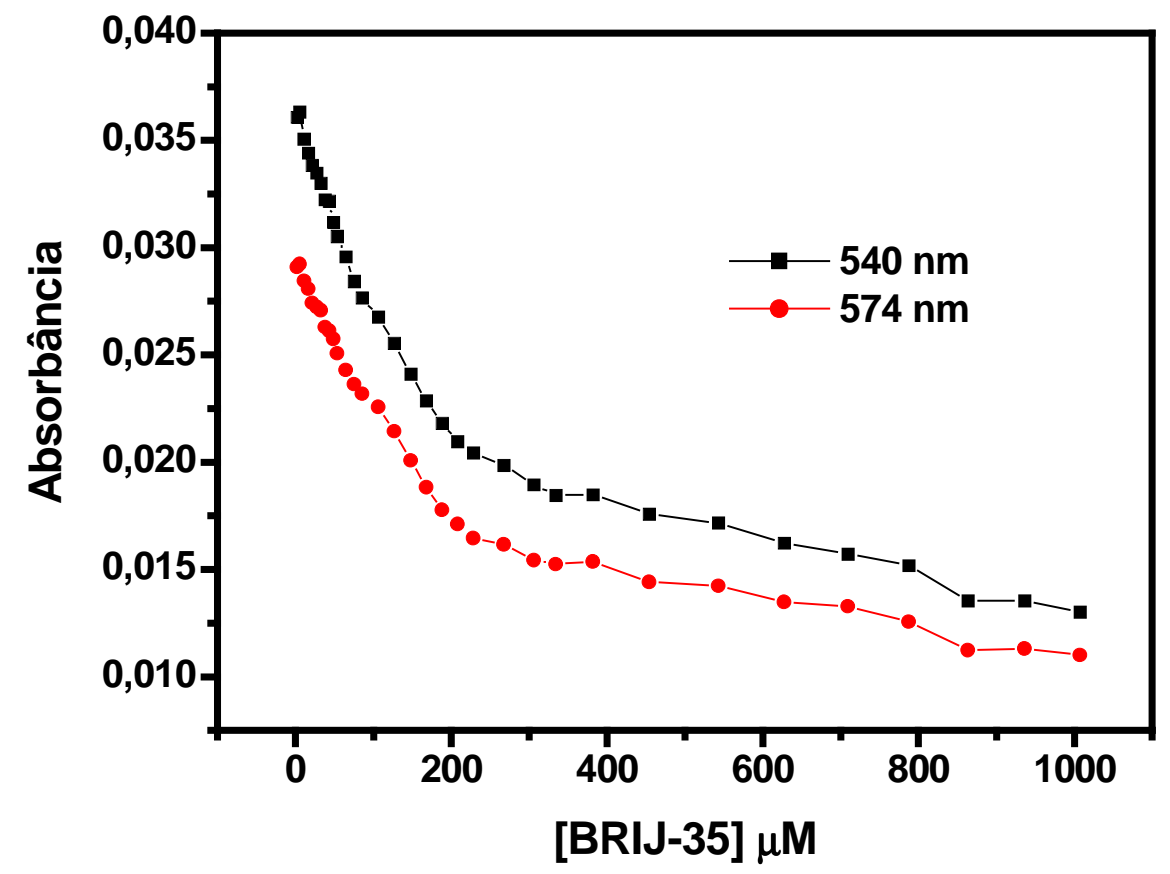

Figura 37: Gráfico de absorbância do oxi-monômero de G. paulistus em tampão Tris-HCl 20 mmol L $^{-1}$ (pH 9,0), em função da concentração de BRIJ-35, na região das bandas Q, $540 \mathrm{~nm}$ e $574 \mathrm{~nm}$, respectivamente.

A figura 38 ilustra a variação da fluorescência total $(A$, área sob a curva de emissão) normalizada pela fluorescência total do monômero na ausência de surfactante, $A_{0}$. As áreas foram previamente corrigidas em relação à variação da absorbância no comprimento de onda de excitação e em relação ao efeito de diluição devido às adições das alíquotas da solução estoque de BRIJ-35.

Na titulação do oxi-monômero pH 9,0 com BRIJ-35 identificou-se três fases. Inicialmente foi observado um aumento no máximo da fluorescência até a concentração de $208 \mu \mathrm{M}$ de BRIJ-35. Para se interpretar a 
intensificação da emissão, atribui-se à alteração da distância e/ou a uma mudança da orientação relativa dos resíduos de TRP em relação ao grupo heme. Para concentrações de BRIJ-35 entre 228-334 $\mu \mathrm{M}$ de BRIJ-35 observaram-se um comportamento constante de fluorescência, e por fim uma diminuição fluorescência ate a concentração $936 \mu \mathrm{M}$ de BRIJ-35 (figura 38). Como o BRIJ-35 é um a molécula de surfactante que possui uma porção polar, ou seja, hidrofóbica, e uma porção apolar (hidrofílica) sem carga, de forma geral pode-se propor que o aumento da fluorescência esta relacionado com a entrada da cadeia hidrofóbica no bolsão do heme, provocando uma desorganização nas cadeias protéicas do oxi-monômero. 


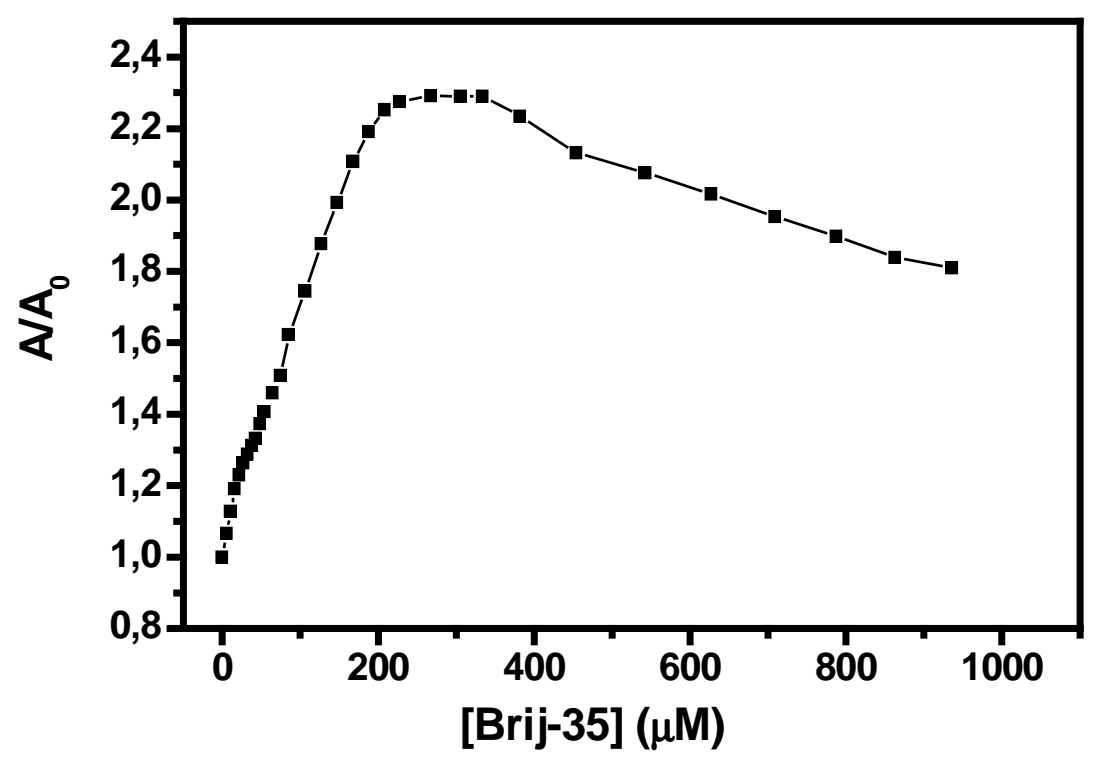

Figura 38: Áreas normalizadas dos espectros de emissão do oxi-monômero de G. paulistus em tampão Tris-HCl $20 \mathrm{mmol} \mathrm{L}^{-1}(\mathrm{pH} 9,0), \lambda_{\mathrm{exc}}=295 \mathrm{~nm}, \lambda_{\mathrm{em}}=305$ $-450 \mathrm{~nm}$, em função da concentração de BRIJ-35.

Para se extrair os parâmetros de interação do detergente com o oximonômero, o conjunto de espectros de fluorescência obtidos em função da concentração de BRIJ-35 (figura 39(A)) foi analisado empregando-se o método CCA (PERCZEL et al. 1992) A análise foi feita considerando-se a variação espectral devido às transformações evolvendo três espécies químicas, e os espectros individuais destes componentes estão apresentados na figura 39(B). A primeira espécie centrada em $328 \mathrm{~nm}$ foi associada ao oxi-monômero puro. A segunda espécie centrada em $331 \mathrm{~nm}$ foi associada ao complexo oximonômero-BRIJ-35 predominante na faixa de $228 \mu \mathrm{M}-334 \mu \mathrm{M}$. A terceira espécie, centrada em $328 \mathrm{~nm}$ foi associada ao monômero desnaturado e é a 
única espécie até $936 \mu \mathrm{M}$ de BRIJ-35. Na figura 39(C) estão apresentadas às contribuições, frações, de cada espécie no espectro experimental em função da concentração de BRIJ-35.

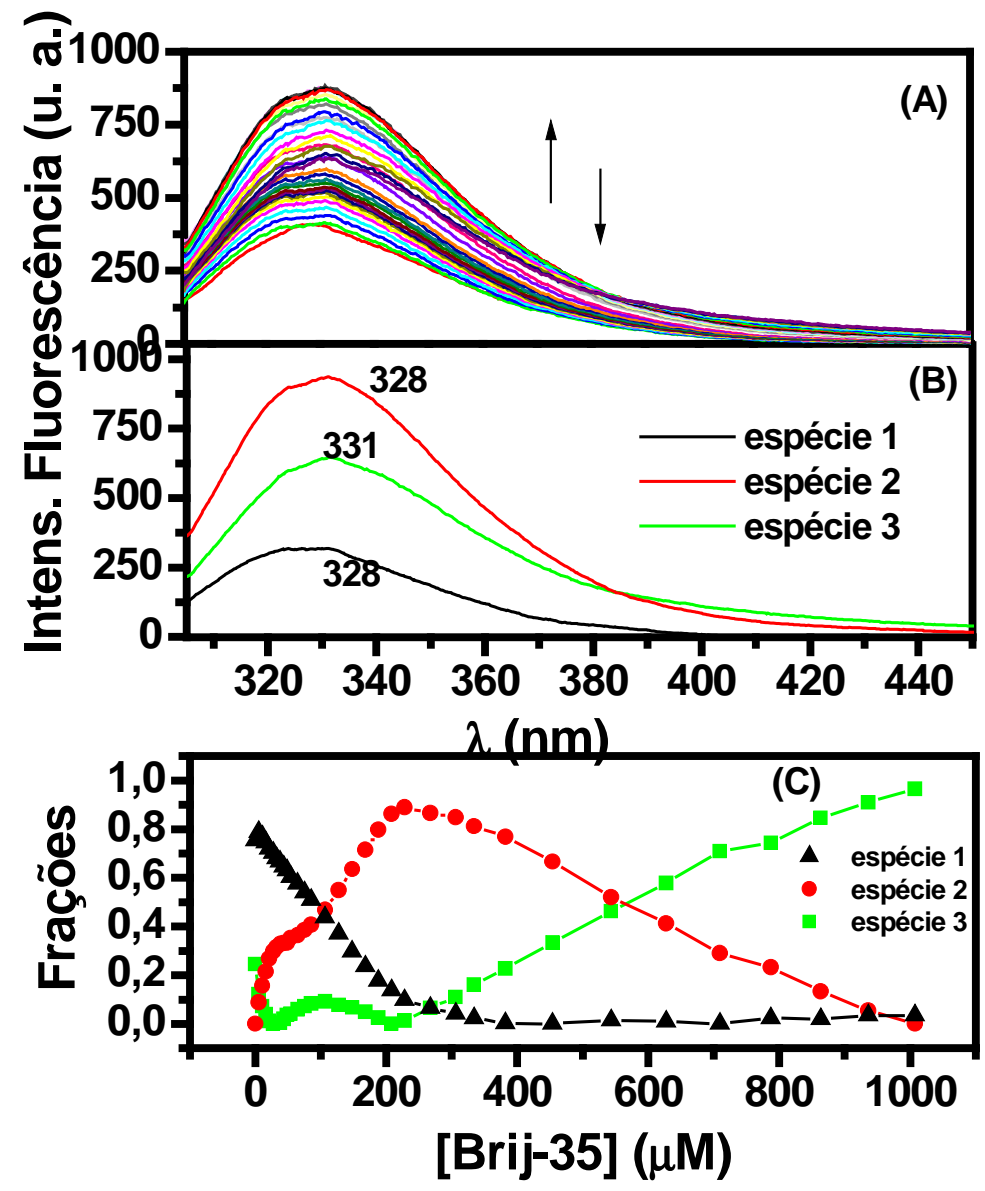

Figura 39: (A) Espectros de emissão do oxi-monômero de G.paulistus em tampão Tris- $\mathrm{HCl} 20 \mathrm{mmol} \mathrm{L} \mathrm{L}^{-1}(\mathrm{pH} 9,0), \lambda_{\text {exc }}=295 \mathrm{~nm}$ em função da concentração de BRIJ-35, (B) espécies puras: oxi-monômero puro (- $\mathbf{\Delta}$-) espécie 1, complexo monômero-BRIJ-35 (-•-) - espécie 2 e monômero desnaturado (-口-) - espécie 3, correspondentes aos componentes dos espectros experimentais presentes em diferentes proporções; (C) conteúdo relativo de cada espécie em função da concentração de BRIJ-35. 


\subsection{Estudo da interação da fração oxi-monômero em pH 7,0 e 9,0 da hemoglobina de G. paulistus (HbGp) com SDS, CTAC e BRIJ-35 através do dicroísmo circular.}

Uma vez realizados estes estudos sobre a estrutura terciária da proteína, iniciou-se uma investigação sobre a sua estrutura secundária e como esta estrutura é alterada na medida em que detergentes são adicionados em solução. A técnica espectroscópica utilizada foi a técnica de dicroísmo circular.

Inicialmente, registraram-se os espectros de dicroísmo circular em função da concentração de detergente para o oxi-monômero em pH 7,0 e 9,0. Nas figuras 32 e 33 os espectros são apresentados e pode-se observar que as modificações produzidas por CTAC são mais consideráveis, enquanto que para o SDS e BRIJ-35, estas modificações são muito menores.

Em meio alcalino, os espectros de dicroísmo circular evidenciam uma perda do conteúdo de estrutura hélice- $\alpha$. Este fato pode ser constatado se forem analisadas as diferenças de intensidade da banda em torno de $222 \mathrm{~nm}$, que se trata de uma região bastante utilizada na literatura para sondar a estrutura polipeptídica (GHIRLANDA et al.2004)(ARNOLD et al.1997). É relevante ressaltar para o fato de que o valor de $\mathrm{pH}$ 10,5 corresponde, aproximadamente, à condição que propicia a formação da espécie pentacoordenada, consequentemente, é possível inferir que tal desenovelamento deve favorecer a formação do heme pentacoordenado, que são fenômenos intrinsicamente relacionados de forma sinérgica, que é 
observado somente para o CTAC. Vale ressaltar também que em pH 9,0 a cadeia monomérica $d$ se dissocia do trímero $a b c$, o que, juntamente com a perda do enovelamento polipeptídico, deve intensificar a acessibilidade do solvente ao bolsão do heme, auxiliando a formação da espécie pentacoordenada (MOREIRA et al.2006).

Uma das interações estabilizadoras do grupo heme nas hemoproteínas, são as ligações iônicas entre os grupos propionatos do heme com grupos catiônicos de resíduos de aminoácidos básicos Arg 66 (E10) e Arg 98 (FG2) (CABRAL et al.2002). Desta forma os resultados indicam que os detergentes catiônicos deslocam com facilidade os resíduos de aminoácidos destas ligações salinas. Convém mencionar que o grupo catiônico do CTAC é constituído por aminas quaternárias, enquanto que os resíduos de Arg 66 e Arg 98 que são bases de Brönsted, ou seja, sensíveis aos equilíbrios de dissociação do próton. Desvencilhado das ligações salinas, o grupo heme fica livre para rodar ao redor do seu eixo $\alpha \gamma$, cujo movimento poderá enfraquecer a ligação do imidazol da histidina distal na $6^{\text {a }}$ posição de coordenação do ferro (MOREIRA et al.2006)(MOREIRA et al.2007), cujo fenômeno facilitará a troca de ligante e eventualmente a transformação para o complexo pentacoordenado. Esta poderá constituir-se também na explicação da auto-oxidação do monômero $d$ da hemoglobina de G. paulistus facilitada pela presença de CTAC. Neste caso a livre rotação irá romper a ligação de hidrogênio com a participação do imidazol da histidina distal, estabilizando o oxigênio molecular na $6^{\underline{a}}$ posição (POLI et 
al.2005)(POLI et al.2006). O distanciamento do imidazol do $\mathrm{O}_{2}$ promovida pela rotação do heme irá desfavorecer a ligação de hidrogênio.

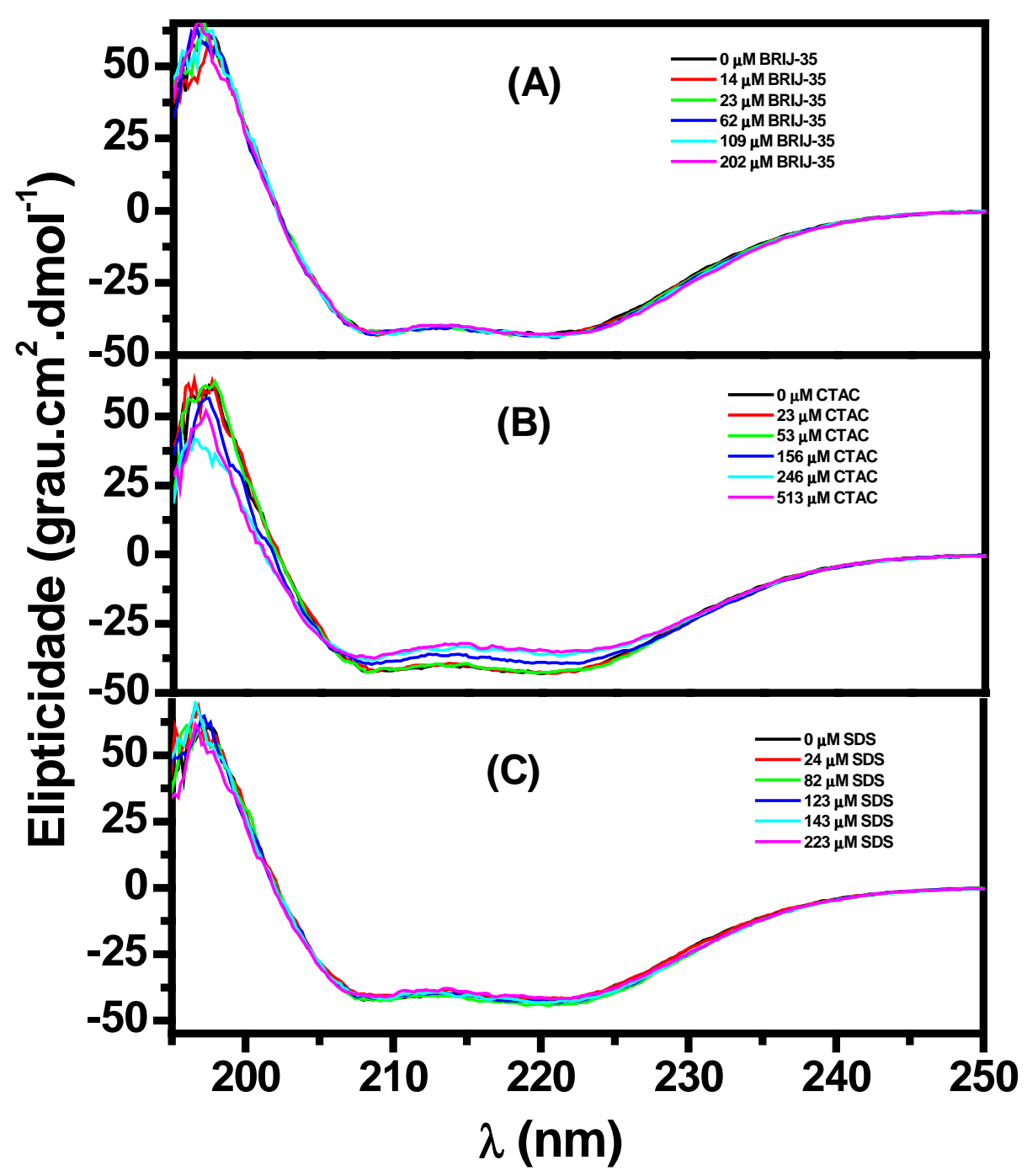

Figura 40: Espectros de dicroísmo circular do oxi-monômero de G. paulistus em tampão Tris- $\mathrm{HCl} 20$ mmol L-1 (pH 7,0) em função da concentração de: (A) BRIJ-35; (B) CTAC; (C) SDS. 


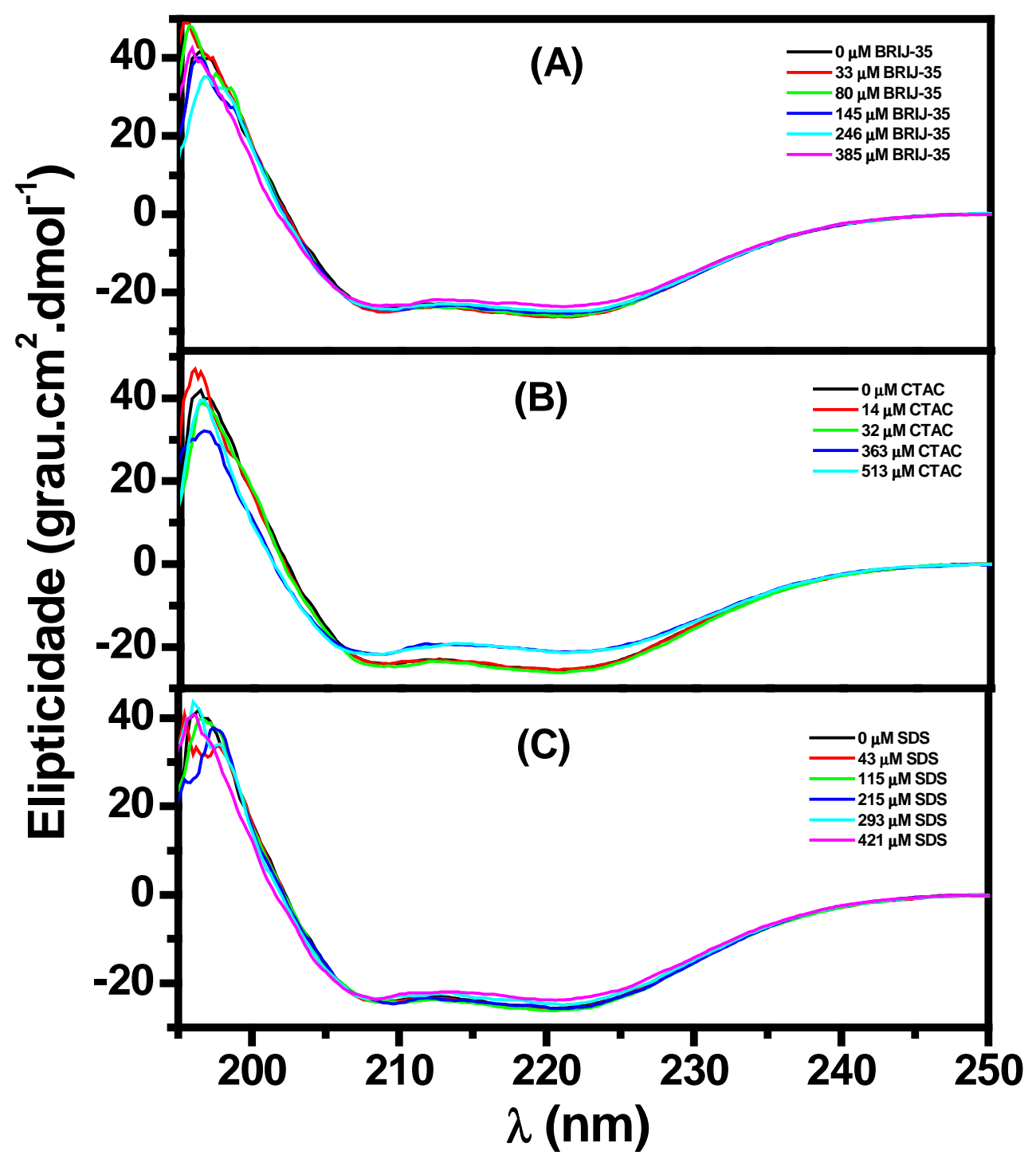

Figura 41: Espectros de dicroísmo circular do oxi-monômero de G. paulistus em tampão Tris-HCl 20 mmol L-1 $(p H ~ 9,0)$ em função da concentração de: (A) BRIJ-35; (B) CTAC; (C) SDS. 


\section{CONCLUSÕES}

A interação da cadeia monomérica $d$ da hemoglobina extracelular gigante de G. paulistus com o detergente catiônico CTAC é maior do que com o aniônico SDS e o neutro BRIJ-35, indicando que a proteína possui uma grande quantidade de sítios aniônicos importantes, em especial aqueles relacionados á estabilização do grupo prostético heme. Esta interação mais efetiva do monômero $d$ de HbGp com CTAC nestes valores de pH 7,0 e 9,0 deve ocorrer devido ao $\mathrm{pl}$ (ponto isoelétrico) da proteína. É conhecido que o ponto isoelétrico de hemoglobinas extracelulares é ácido. Este pode ser um importante fator para explicar a interação mais efetiva do CTAC em meio alcalino. Para valores de pH maiores que o pl da proteína $(\mathrm{pl}=5,5)$, ocorre um aumento de sítios aniônicos disponíveis para a interação com o CTAC.

Os estudos da interação do monômero $d$ em pH 7,0 e 9,0 com surfactante SDS por absorção UV-Vis, revelaram a oxidação da cadeia pela formação de bandas em $535 \mathrm{~nm}$ e $565 \mathrm{~nm}$ o que caracteriza a formação de hemicromo. Para o surfactante neutro BRIJ-35 em pH 7,0 e 9,0 foram observados a diminuição das bandas de Soret $(414 \mathrm{~nm}$ ) e das bandas Qs (538 nm e 573 nm). A interação com CTAC tanto em pH 7,0 e 9,0 foi observada o deslocamento da banda de Soret para $401 \mathrm{~nm}$, diminuição das duas bandas $\mathrm{Q}$ e a formação de uma banda em 605 nm, cujas alterações espectrais são características da formação de espécie pentacoordenada. 
Os estudos de fluorescência do monômero $d$ da hemoglobina de $G$. paulistus em $\mathrm{pH}$ 7,0 e 9,0 com os surfactantes CTAC, SDS e BRIJ-35, indicam um aumento do rendimento quântico, pois os surfactantes tende a se ligar a sítios específicos, causando assim, mudanças na cadeia polipeptídica, consequentemente, alterando as orientações e distâncias relativas dos dipolos de transições do Trp e do grupo heme alterando a eficácia da transferência de energia pelo mecanismo de Förster, bem como expondo mais os resíduos de Trp ao solvente.

Nos estudos de dicroísmo circular é relevante ressaltar que a interação com o surfactante CTAC proporciona a formação da espécie pentacoordenada, devido ao desenovelamento da cadeia polipeptídica. Para o SDS e o BRIJ-35 foi observado uma pequena perda da estrutura secundária do monômero $d$. 


\section{REFERÊNCIAS BIBLIOGRÁFICAS}

AGUSTINHO, S. C. M.; TINTO, M. H.; IMASATO, H.; TOMINAGA, T. T.;PERUSSI, J.R; TABAK, M.;. Spectroscopy studies of the met form of the extracellular hemoglobin from Glossoscolex paulistus. Biochimica et Biophysica Acta, v. 1298, p.148-158, 1996.

AGUSTINHO, S. C. M.; TINTO, M. H.; PERUSSI, J. R.; TABAK, M.; IMASATO, $\mathrm{H}$. Fluorescence studies of extracellular hemoglobin of Glossoscolex paulistus in met form obtained from sephadex gel filtration. Comparative Biochemistry Physiology, v. 118A, p.171-181, 1997.

AGUSTINHO, Silvana Cardoso Miguel. Estudo espectroscópico da metahemoglobina e globina de Glossoscolex paulistus. São Carlos, 1995. 151p. Tese (Doutorado) - Instituto de Química de São Carlos, Universidade de São Paulo.

ACKERS, G. K.; DOYLE, M. L.; MYERS, D.; DAUGHERTY, M. A. Molecular Code for Cooperativity in Hemoglobin. Science, v. 255, p. 54-63, 1992.

ANTONINI, E.; ROSSI-BERNARD, L.; CHIANCONE, E. Methods in Enzimology. New York, Academic Press, 1981, v.76.

ARNDT, M. H. L.; SANTORO, M. M. Structure of the extracellular hemoglobin of Biomphalaria glabrata. Comparative Biochemistry and Physiology Part B, v. 119, p. 667-675, 1998. 
ARNOLD, E. V.; BOHLE, D. S.; JORDAN, P. A.; Reversible and Irreversible Hemichrome Generation by the Oxygenation of Nitrosylmyoglobin. Biochemistry, v. 38, n. 15, p. 4750-4756, 1999.

BAILLY, X.; VINOGRADOV, S. The sulfide binding function of annelid hemoglobins: relic of na old biosystem? Journal of Inorganic Biochemistry, v. 99, p. $142-150,2005$.

BARNES, R. D. Invertebrate Zoology. 4 ed Philadelsia, Saudes Colleges, 1980.

BARON, C. P.; SKIBSTED, L. H.; ANDERSEN, H. J. Peroxidation of linoleate at physiological $\mathrm{pH}$ : Hemichrome formation by substrate binding protects against metmyoglobin activation by hydrogen peroxide. Free Radical Biology and Biology, v. 28, n. 4, p. 549-558, 2000.

BONAFE, C. F. S; VILLASBOAS, M; SUAREZ, M. C. Reassembly of a large multisubunit protein promoted by nonprotein factors - effects of calcium and glycerol on the association of extracellular hemoglobin. Journal of Biologycal Chemistry, v. 266, p. 13210-13216, 1991.

CABRAL, C. B.; IMASATO, H.; ROSA, J. C.; LAURE, H. J.; SILVA, C. H. T. P.; TABAK, M.; GARRAT, R. C.; GREENE, L. J. Fluorescence properties of tryptophan residues in the monomeric d-chain of Glossoscolex paulistus 
hemoglobin: an interpretation based on a comparative molecular model. Biophysical Chemistry, v.97, p.139-157, 2002.

CABRAL, Carolina Bosch. Determinação da estrutura primária e modelagem molecular por homologia estrutural da estrutura terciária da cadeia $d$ da hemoglobina extracelular gigante de Glossocolex paulistus. São Carlos, 1999. 100p. Dissertação (Mestrado) - Instituto de Química de São Carlos, Universidade de São Paulo.

CANTOR, R. C. Techniques for the study of biological structure and function. New York, W. H. Freemam, 1980, v.2.

COSTA, M. C. P.; BONAFÉ, C. F. S; MEIRELES, N. C.; GALEMBECK, F.; Brazilian Journal of Medical Research, v. 21, p. 115, 1988.

DASGUPTA, S.; ROUSSEAU, D. L.; ANNI, H.; YONETANI, T. Structural Characterization of Cytochrome $c$ Peroxidase by Resonance Raman Scattering. The Journal of Biological Chemistry, v. 264, n. 1, p. 654-662, 1989.

DANIEL, E.; LUSTIG, A.; DAVID, M. M.; TSFADIA, Y. On the molecular mass of Lumbricus erythrocruorin. Micron, v. 35, p. 131-132, 2004.

DICKERSON, R. E.; GEYS, I. Hemoglobin: structure, function, evolution and pathology. Menlo Park, Califórnia, The Benjamin Cumings, 1983. 176p. 
DORMAN, S. C.; HARRINGTON, J. P.; MARTIN, M. S.; JOHNSON, T. V. Determination of the formal reduction potential of Lumbricus terrestris hemoglobin using thin layer spectroeletrochemistry. Journal of Inorganic Biochemistry, v. 98, p. 185-188, 2004.

DREW, A.; DUNIETZ, B. D.; HEAD-GORDON, M. Characterization of the Relevant Excited States in the Photodissociation of CO-Ligated Hemoglobin and Myoglobin. Journal of the American Chemical Society, v. 124, p. 12070-12071, 2002.

FASMAN, G. D. Circular dicroism and the analysis of biomolecules. New York, Plenum Press, 1996. 738 p.

FERNANDEZ, S. P. Isolamento do trímero e suas subunidades $a, b, c$ da hemoglobina de Glossoscolex paulistus e caracterização por análise de aminoácidos. São Carlos, 2001 77p. . Dissertação de mestrado Instituto de Química de São Carlos, Universidade de São Paulo.

GELAMO, E. L. Estudos espectroscópicos das interações da hemoglobina extracelular de Glossocolex paulistus com surfactantes iônicos. São Carlos, 1999. 118. Dissertação de Mestrado - Instituto de Química de São Carlos, Universidade de São Paulo. 
GELAMO, E. L. Estudos espectroscópicos das interações da hemoglobina extracelular de Glossocolex paulistus e albuminas humana (HSA) e bovina (BSA) com surfactantes iônicos. São Carlos, 2003. 144p. Tese de Doutorado Instituto de Química de São Carlos, Universidade de São Paulo.

GELAMO, E. L.; ITRI, R.; TABAK, M. Smal Angle X-Ray Scattering (SAXS) Study of the Extracellular Hemoglobin of Glossoscolex paulistus: Effect of $\mathrm{pH}$, Iron Oxidation State and Interaction with Anionic SDS Surfactant. The Journal of Biological Chemistry, v. 279, n. 32, p. 33298-33305, 2004.

GHIRLANDA, G.; OSYCZKA, A.; LIU, W.; ANTOLOVICH, M.; SMITH, K. M.; DUTTON, P. L.; WAND, A. J.; DEGRADO, W. F. De Novo Design of a $D_{2-}$ Symmetrical Protein that Reproduces the Diheme Four-Helix Bundle in Cytochrome $b c_{1}$. Journal of the American Chemical Society, v. 126, n. 26, p. 8141-8147, 2004.

GILLES-GONZALEZ, M. A.; GONZALEZ, G.; PERUTZ, M. F.; KIGER, L.; MARDEN, M. C.; POYART, C. Heme-Based Sensors, Exemplified by the Kinase FixL, Are a New Class of Heme Protein with Distinctive Ligand Binding and Autoxidation. Biochemistry, v. 33, p. 8067-8073, 1994.

GREEN, B.N.; BORDOLIS, R.S.; HANIN, L.G.; LALLIER, F.H.; TOULMOND, A.; VINOGRADOV, S.N. The Journal of Biological Chemistry, v. 274, n. 40, p. 28206-28212, 1999.

GREEN, B. N.; VINOGRADOV, S. N. An Electrospray lonization Mass Spectrometric Study of the Subunit Structure of the Giant Hemoglobin from the 
Leech Nephelopsis oscura. Journal of the American Society for Mass

Spectrometry, v. 15, p. 22-27, 2004.

GRYCZNSKI, Z.; FRONTICELLI, C.; TENENHOLZ, T.; BUCCI, E. Effect of disordered hemes on energy transfer rates between tryptophans and heme in myoglobin. Biophysical Journal, v.65, p.1951-1958, 1993.

HAAS, F.; KUCHUMOV, A.; TAVEAU, J. C.; BOISSET, N.; VINOGRADOV, S. N.; LAMY, J. N. Biochemistry, v. 36, 1997.

HARRINGTON, J. P. Role of monovalent divalent-cations on multimeric Lumbricus hemoglobin stabilization. Biophysical Journal, v. 66, p: A361-A361 Part: 2, 1994.

HELENIUS, A.; SIMONS, K. Solubilization of membranes by detergents. Biochimica et Biophysica Acta, v. 415, p. 29-79, 1975.

HIRSCH, R. E.; JELICKS, L. A.; WITTENBERG, B.; KAUL, D. K.; SHEAR, H. L.; HARRINGTON, J. P. A first evaluation of the natural high molecular weight polymeric Lumbricus terrestris hemoglobin as an oxygen carrier. Artifical Cells, Blood Substitutes and Immobilization Biotechnology, v. 25, n. 5, p. 429444, 1997.

IMASATO, H.; TINTO, M. H.; PERUSSI, J. R.; TABAK, M. Fluorescence studies of extracellular hemoglobin of Glossoscolex paulistus obtained by gel filtration. Comparative Biochemistry Physiology, v.112B, p.217-226, 1995.

JONES, M. N.; CHAPMAN, D. Micelles, monolayers and biomembranes. New York, John Wiley \& Sons, 1995, p. 143-179. 
KALYANASUNDARAM, K. Photochemistry in Microheterogeneus Systems. Academic Press, New York, 1987.

KAPP, O. H.; POLIDORI, G.; MAINWARING, M. G.; CREWE, A. V.;

VINOGRADOV, S. N. The Reassociation of Lumbricus terrestris Hemoglobin Dissociated at Alkaline $\mathrm{pH}^{\star}$. The Journal of Biological Chemistry, v. 259, n. 1, p. 628-639, 1984.

KREBS, A.; ZIPPER, P.; VINOGRADOV, S. N. Lack of size and shape alteration of oxygenated and deoxygenated Lumbricus terrestris hemoglobin? Biochimica et Biophysica Acta, v. 1297, p. 115-118, 1996.

KREBS, A.; VINOGRADOV, S. N.; ZIPPER, P. Biopolymers, v. 45, p. 289, 1998.

KUCHUMOV, A. R.; TAVEAU, J. C.; LAMY, J. N.; WALL, J. S.; WEBER, R. E.; VINOGRADOV, S. N. The role of Linkers in the reassembly of the 3. $6 \mathrm{MDa}$ hexagonal bilayer hemoglobin from Lumbricus terrestris. Journal of Molecular Biology, v. 289, p. 1361-1374, 1998.

LAKOWICZ, J. Principles of fluorescence spectroscopy. New York, Plenum Press, 1983. 500p.

LA MAR, G. R.; DAVIS, N. L.; PARISH, D. W.; SMITH, K. M. Heme orientational disorder in reconstituted and native sperm whale myoglobin. Journal of Molecular Biology, v.168, p. 887-896, 1983.

LA MAR, G. N.; TOI, H.; KRISHNAMOORTHI, R. Proton NMR Investigation of the Rate and Mechanism of Heme Rotation in Sperm Whale Myoglobin: 
Evidence for Intramolecular Reorientation about a Heme Twofold Axis. Journal of the America Chemical Society, v. 106, p. 6395-6401, 1984.

LAMY, J. N.; GREEN, B.; TOULMOND, A.; WALLS, J.; WEBER, R.; VINOGRADOV, S. Giant hexagonal bilayer hemoglobins. Chemical Reviews, v. 96, p. 3113-3124, 1996.

LEVES, A. L. P. Estudo da auto-oxidação da hemoglobina de Glossoscolex paulistus: efeito do cianeto, azida e imidazol em pH 9,0. São Carlos, 2001 76p Dissertação de Mestrado Instituto de Química de São Carlos, Universidade de São Paulo.

LEVY, A.; KUPPUSAMY, P.; RIFKIND, J. M. Multiple Heme Pocket Subconformations of Methemoglobin Associated with Distal Histidine Interactions. Biochemisty, v. 29, p. 9311-9316, 1990.

MADURA, J. D.; SALTER, E. A.; WIERZBICKI, A.; DALAL, P.; HARRINGTON, J. P. Homology models for the tetrameric and dodecameric complexes of Lumbricus terrestris hemoglobin. Journal of Molecular Structure (Theochem), v. 592, p. 173-181, 2002.

MARQUES, M. B.; MEIRELLES, N. C. Erythrocruorin of Glossoscolex paulistus (Righi)(Oligochaeta, Glossoscolecidae): effects of divalent ions, acid-alkaline transition and alkali and urea denaturation. Comparative Biochemistry and Physiology, Part B: Biochemistry \& Molecular Biology, v. 111, n. 2, p. 311318, 1995. 
MARTIN, P. D.; KUCHUMOV, A. R.; GREEN, B. R. Mass Spectrometric Composition and Molecular Mass of Lumbricus terrestris hemoglobin: A Refined model of its quaternary structure. Journal of Molecular Biology, v. 225, p. 154$169,1996$.

MEIRELLES, N. C.; OLIVEIRA, B.; OLIVEIRA, A. R.; DE PAULA, E.; MARANGONI, S.; RENNEBECK, G. M. Erythrocruorin of Glossoscolex paulistus (Oligochaeta, Glossoscolecidae) Dissociation at Alkaline $\mathrm{pH}$ and Its Ligand Properties as Revealed by Chemical, Immunochemical and Electronmicroscopy. Comparative Biochemitry and Physiology, Part A: Molecular \& Integrative Physiology, v. 88, p. 377-379, 1987.

MOREIRA, L. M. ; RIBELATTO, J. C. ; IMASATO, H. Conformações distorcida e planar do anel porfirínico em complexos e hemoproteínas: propriedades físicoquímicas e implicações espectroscópicas. Química Nova, v. 27, n. 6, p. 958963, 2004.

MOREIRA, Leonardo Marmo. Espécies formadas no centro férrico da hemoglobina de Glossocolex paulistus em função do $\mathrm{pH}$ : troca de ligantes e desenovelamento polipeptídico. São Carlos, 2005. 1179p. Tese (Doutorado) Instituto de Química de São Carlos, Universidade de São Paulo.

MOREIRA, L. M.; POLI, A. L.; COSTA-FILHO, A. J.; IMASATO, H.; Pentacoordinate and hexacoordinate ferric hemes in acid médium: EPR, UV-Vis and CD studies of the giant extracellular hemoglobin of Glossoscolex paulistus Biophysical Chemistry, v. 124, p. 62-72, 2006.

MOREIRA, L. M.; POLI, A. L.; COSTA-FILHO, A. J.; IMASATO, H.; Ferric species equilibrium of the giant extracellular hemoglobin of Glossoscolex 
paulistus in alkaline medium: HALS hemichrome as a precursor of pentacoordinate species. International Journal of Biological Macromolecules, v. 42, p. 103-110, 2008.

MORIKIS, D.; CHAMPION, P. M.; SPRINGER, B. A.; SLIGAR, S. G. Resonance Raman Investigations of Site-Directed Mutants of Myoglobin: Effects of Distal Histidine Replacement. Biochemistry, v. 28, n. 11, p. 4791-4800, 1989.

MOUCHE, F.; BOISSET, N.; PENCZEK, P. A.; Journal of Structural Biology, 133, 176, 2001.

NAGATOMO, S.; JIN, Y.; NAGAI, M.; HORI, H.; KITAGAWA, T. Changes in the abnormal $\alpha$-subunit of $\mathrm{Hb}$ M Boston: resonance Raman, EPR and CD study. Biophysical Chemistry, v. 98, p. 217-232, 2002.

OWNBY, D. W.; ZHU, H.; SCHNEIDER, K.; BEAVIS, R. C.; CHAIT, B. T.; RIGGS, A. F. The extracellular Hemoglobin of the Earthworm, Lumbricus terrestris: Determination of subunit stoichiometry. The Journal of Biological Chemistry, v.268, p.13539-13547, 1993.

PERCZEL, A.; PARK, K.; FASMAN, G. D. Analysis of the Circular-Dichroism spectrum of proteins using the Convex Constraint Algorithm - A practical guide. Analytical Biochemistry, v.203, p.83-93, 1992.

PIETRI, R.; GRANELL, L.; CRUZ, A.; DE JESÚS, W.; LEWIS, A.; LEON, R.; CADILLA, C. L.; GARRIGA, J. L. Tyrosine B10 and heme-ligand interactions of Lucina pectinata hemoglobin II: control of heme reactivity. Biochimica et Biophysica Acta, v. 1747, p. 195-203, 2005. 
POLI, A. L.; MOREIRA, L. M.; TABAK, M; IMASATO, H. SDS (sodium dodecyl sulfate) effect on the autoxidation of the Glossoscolex paulistus giant extracellular hemoglobin: Kinetc studies at pH 7.0 and 9.0. Colloids and Surfaces B, v. 52, p. 96-104, 2006.

POLI, A. L.; MOREIRA, L. M.; HIDALGO, A. A.; IMASATO, H. Autoxidation studies of hemoglobin Glossoscolex paulistus at $\mathrm{pH}$ 9: cyanide and hydroxyl effect. Biophysical Chemistry, v. 114, p. 253-260, 2005.

RACHMILEWITZ, E. A.; PEISACH, J.; BLUMBERG, W. E. Studies on the Stability of Oxyhemoglobin A and Its Constituent Chains and Their Derivatives. The Journal of Biological Chemistry, v. 246, n. 10, p. 3356-3366, 1971.

REZA, D. M; AKBAR, M. M. A; PARVIZ, N. Inhibition of human hemoglobin autoxidation by sodium $n$-dodecyl sulphate. Journal of Biochemistry and Molecular Biology, v. 35 p. 364-370, 2002.

RIBELATTO, J. C. Reconstituição do monômero $d$ da hemoglobina extracelular gigante de Glossoscolex paulistus acompanhada por técnicas espectroscópicas. São Carlos, 2003 95p Dissertação de Mestrado, Instituto de Química de São Carlos, Universidade de São Paulo.

RIBELATTO, J. C.; POLI, A. L.; MOREIRA, L. M.; IMASATO, H. Hemes férricos pentacoordenados e hexacoordenados dos monômeros $d$ nativo e reconstituído da hemoglobina extracelular de Glossoscolex paulistus: estudos espectroscópicos em meio ácido. Química Nova, v. 28, n. 5, p. 829-833, 2005.

RIBELATTO, J. C.; POLI, A. L.; MOREIRA, L. M.; IMASATO, H. Estudo espectroscópico do equilíbrio entre espécies hexacoordenada e 
pentacoordenada dos monômero $d$ nativo e reconstituído da hemoglobina extracelular gigante de Glossoscolex paulistus em meio alcalino. Química Nova, v. 29, n. 4, p. 666-673, 2006.

RIGGS, A. R.; SUZUKI, T. Linker chain L1 of earthworm hemoglobin, structure of gene and protein: homology with low density lipoprotein receptor. The Journal of Biological Chemistry, v. 268, p. 13548-13555, 1993.

RIGGS, A. F. Self-Association, Cooperativity and Supercooperativity of Oxygen Binding by Hemoglobins. The Journal of Experimental Biology, v. 201, p. 1073-1084, 1998.

RIGHI, G. Topography of Circulatory System of Glossoscolex paulistus Michaelsen 1926 (Oligochaeta Glossoscolecidae). Monitore Zoology Italian, v. 6, p. 19-36, 1972.

ROSSI, J. -P.; NUUTINEM, V The effect of sampling unit size on the perception of the spatial pattern of earthworm (Lumbricus terrestris L. ) middens Applied Soil Ecology, v. 27, p. 189-196, 2004.

ROYER JUNIOR, W. E.; STRAND, K.; HEEL, M. V.; HENDRICKSON, W. A. Structural hierarchy in erythrocruorin, the giant respiratory assemblage of annelids. Proceedings of the National Academy of Sciences of the United States of America, v.97, p.7107-7111, 2000.

ROYER JUNIOR, W. E.; KNAPP, J. E.; STRAND, K.; HEASLET, H. A. Cooperative hemoglobins: conserved fold, diverse quaternary assemblies and allosteric mechanisms. Trends in Biochemical Sciences, v.26, n.5, p.297-304, 2001. 
SANTIAGO, P. S.; MOREIRA, L. M.; ALMEIDA, E. V.; TABAK, M. Giant extracellular Glossoscolex paulistus hemoglobin (HbGp) upon interaction with cethyltrimethylammonium chloride (CTAC) and sodium dodecyl sulphate (SDS) surfactants: dissociation of oligomeric structure and autoxidation. Biochimica et Biophysica Acta, v. 1770, n.4, p.506-517, 2007.

SATOH, Y. AND SHIKAMA, K. Autoxidation of mioglobin: A nucleophilic displancement mechanism. The Journal of Biological Chemistry, v. 256, p. 10272-10275, 1981.

SILVA, J. L.; VILLAS-BOAS, M.; BONAFE, C. F. S.; MEIRELLES, N. C. Anomalous Pressure Dissociation of Large Protein Aggregates. The Journal of Biological Chemistry, v. 264, n. 27, p. 15863-15868, 1989.

SILVERSTEIN, R. M.; BASSLER, G. C.; MORRIL, T. C. Identificação Espectroscópica de compostos orgânicos. Rio de Janeiro, Guanabara Koogan, 1994. p.340.

SOUTO, A. L. C. F.; ITO, A. Tryptophan fluorescence studies of melanotropins in the amphiphile-water interface of reversed micelles. European Journal of Biochemistry, v. 29, p.38-47, 2000.

SHIKAMA, K. The Molecular Mechanism of Autoxidation for Myoglobin and Hemoglobin: A Venerable Puzzle. Chemical Reviews, v. 98, p. 1357-1373, 1998.

STRAND, K.; KNAPP, J. E.; BHYRAVBHATIA, B.; ROYER Jr, W. E. Crystal Structure of the Hemoglobin Dodecamer from Lumbricus Erythrocruorin: 
Allosteric Core of Giant Annelid Respiratory Complexes. Journal of Molecular Biology, v. 344, p. 119-134, 2004.

STRYER, Lubert. Biochemistry. 4.ed. New York, W. H. Freeman, 1988. p.141176.

SUZUKI; T.; KOBOYASHI, M.; FURUKOHRI, T.; GOTHO, T. Autoxidation of extracellular oxyhemoglobin from the polychaete Perenis Brevicirris (Grube), Comparative Biochemitry and Physiology, v. 75B, p. 17-21, 1983.

SZABO, A. G. The fluorescence properties of aromatic amino acids: their role in the undestanding of enzyme structure and dynamics. The enzyme catalysis process. Plenum, 1989.

TAKASHIMA, S.; KUCHUMOV, A.R.; VINOGRADOV, S.N. The apparently symmetrical hexagonal bilayer hemoglobin from Lumbricus terrestris has a large dipole moment. Biophysical Chemistry, v.77, p.27-35, 1999.

TANFORD, C. The hydrophobic effect: formation of micelles and biological membranes. Malabar, Krieger, 1973. 233p.

TAVEAU, J.C.; BOISSET, N.; VINOGRADOV, S.N.; LAMY, J.N. Threedimensional reconstruction of Lumbricus terrestris hemoglobina t 22 angstrom resolution: Intramolecular localization of the globin and linker chain. Journal of Molecular Biology, v. 289, p. 1343-1359, 1999. 
TINTO, Maria Helena. Caracterização das subunidades da hemoglobina de Glossoscolex paulistus. São Carlos, 1994. 82p. Dissertação (Mestrado) Instituto de Química de São Carlos, Universidade de São Paulo.

TURRO, N. J.; LEI, X. G. Spectroscopic probe analysis of protein-surfactant interactions-the BSA/SDS system. Langmuir, v.11, p.2525-2533, 1995.

TRENT III, J. T.; HVITVED, A. N.; HARGROVE, M. S. A Model for Ligand Binding to Hexacoordinate Hemoglobins. Biochemistry, v. 40, n. 20, p. 61556163, p. 2001.

TSURUGA, M.; MATSUOKA, A.; HACHIMORI, A.; SUGAWARA, Y.; SHIKAMA, $K$. The molecular Mechanism of Autoxidation for Human Oxyhemoglobin: Tilting of the Histidine Causes Nonequivalent Oxidation in the $\beta$ Chain. The Journal of Biological Chemistry, v. 273, p. 8607-8615, 1998.

VIANA, E.; SILVA, C. H. T. P.; TABAK, M.; IMASATO, H.; GARRAT, R. A molecular model for the $d$ chain of the giant haemoglobin from Lumbricus terrestris and its implications for subunit assembly. Biochimica et Biophysica Acta, v. 1383, p. 130-142, 1998.

VINOGRADOV, $\mathrm{S}$. The stoichiometry of the four linker subunits of Lumbricus terrestris hemoglobin suggests an asymetric distribution. Micron, v. 35, p. 127129, 2004.

VITAGLIANO, L.; BONOMI, G.; RICCIO, A.; PRISCO, G. D.; SMULEVICH, G. ; MAZZARELLA, L. The Oxidation Process of Antartic Fish Hemoglobins.

European Journal of Biochemistry, v. 271, p. 1651-1659, 2004. 
WAJNBERG, E.; BEMSKI, G.; EL-JAICK, J.; ALVES, O. C. Nitrosyl Hemoglobins: EPR above 80K. International Journal of Biological Macromolecules, v. 18, p. 231-235, 1996.

YAMAMOTO, Y.; NAKASHIMA, T.; KAWANO, E.; CHÛJÔ, R. 1H-NMR investigation of the influence of the heme orientation on functional properties of myoglobin. Biochimica et Biophysica Acta., v.1388, p.349-362, 1998.

YAMAKI, M.; KUBOTA, K.; MATSUBARA, K.; EBINA, S. ; GOTOH, T. Carbohydrate Gluing Is a Strategy for Supramolecular Clamping of Submultiples in Annelid Extracellular Multi-subunit Hemoglobin. Archives of Biochemistry and Biophysics, v. 355, n. 1, p. 119-123, 1998.

ZAL, F.; GREEN, B. N.; MARTINEU, P.; LALLIER, F. H.; TOULMOND, A.; VINOGRADOV, S. N.; CHILDRESS, J. J. Polypeptide chain composition diversity of hexagonal-bilayer haemoglobins within a single family of annelids, the Alvinellidae. European Journal of Biochemistry, v. 267, p. 5227-5236, 2000.

ZIPPER, P.; KREBS, A. Progress in Colloid \& Polymer Science, v. 191, p. 141, 2002.

ZHU, H.; OWNBY, D. W.; RIGGS, C. K.; NOLASCO, N. J.; STOOPS, J. K.; RIGGS, A. F. Assembly of the Gigantic Hemoglobin of the Earthworm Lumbricus terrestris. The Journal of Biological Chemistry, v. 271, n. 47, p. 30007-30021, p. 1996. 
ZHU, Y.; CHENG, G.; DONG, S. Structural electrochemical study of hemoglobin by in situ circular dichroism thin layer spectroelectrochemistry. Biophysical Chemistry, v. 97, p. 129-138, 2002. 